Editora UFPel

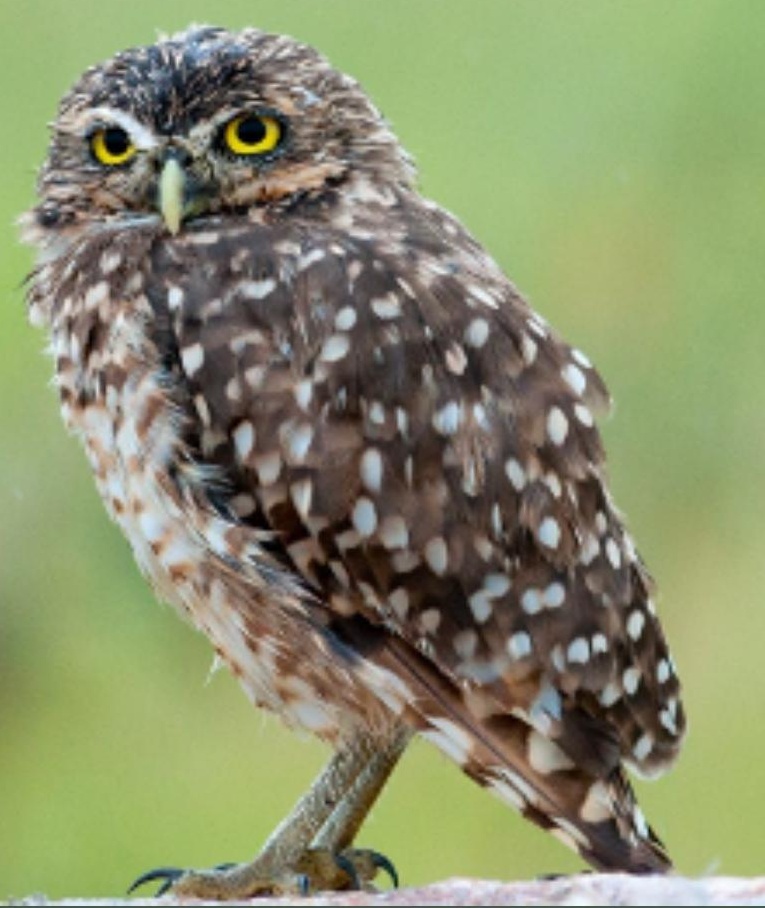

\title{
A MEDIAÇÃO IMPERFEITA EM PAUL RICOEUR
}

Adriane da Silva Machado Möbbs

\author{
DiSSERTATIO \\ FILOSOFIA
}


A MediaÇÃo IMPERfEITA EM PAUL RICOEUR 
Série Dissertatio Filosofia

\section{A MEdiaÇÃo IMPERFEITA EM PAUL RICOEUR}

Adriane da Silva Machado Möbbs

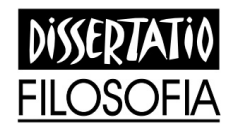

Pelotas, 2017 


\section{Reitoria}

Reitor: Pedro Rodrigues Curi Hallal

Vice-Reitor: Luis Isaías Centeno do Amaral

Chefe de Gabinete: Aline Elias Lamas

Pró-Reitor de Graduação: Maria de Fátima Cóssio

Pró-Reitor de Pesquisa e Pós-Graduação: Flávio Fernando Demarco

Pró-Reitor de Extensão e Cultura: Francisca Ferreira Michelon

Pró-Reitor de Planejamento e Desenvolvimento: Otávio Martins Peres

Pró-Reitor Administrativo: Ricardo Hartlebem Peter

Pró-Reitor de Infraestrutura: Julio Carlos Balzano de Mattos

Pró-Reitor de Assuntos Estudantis: Mário Renato de Azevedo Jr.

Pró-Reitor de Gestão Pessoas: Sérgio Batista Christino

\section{Conselho Editorial}

Presidente do Conselho Editorial: João Luis Pereira Ourique

Representantes das Ciências Agronômicas: Guilherme Albuquerque de Oliveira Cavalcanti Representantes da Área das Ciências Exatas e da Terra: Adelir José Strieder Representantes da Área das Ciências Biológicas: Marla Piumbini Rocha Representante da Área das Engenharias e Computação: Darci Alberto Gatto Representantes da Área das Ciências da Saúde: Claiton Leoneti Lencina Representante da Área das Ciências Sociais Aplicadas: Célia Helena Castro Gonsales Representante da Área das Ciências Humanas: Charles Pereira Pennaforte Representantes da Área das Linguagens e Artes: Josias Pereira da Silva

\section{Editora}

Chefia: João Luis Pereira Ourique (Editor-chefe)

Seção de Pré-produção: Isabel Cochrane (Administrativo)

Seção de Produção: Gustavo Andrade (Administrativo)

Anelise Heidrich (Revisão)

Ingrid Fabiola Gonçalves (Diagramação)

Seção de Pós-produção: Madelon Schimmelpfennig Lopes (Administrativo)

Morgana Riva (Assessoria) 


\section{Série Dissertatio Filosofia}

A Série Dissertatio Filosofia, uma publicação do Núcleo de Ensino e Pesquisa em Filosofia (NEPFil) em parceria com a Editora da Universidade Federal de Pelotas, tem por objetivo precípuo a publicação de estudos filosóficos que possam contribuir para 0 desenvolvimento da Filosofia no Brasil nas mais diversas áreas de investigação. Conheça nosso acervo.

Sobre Normatividade e Racionalidade Prática João Hobuss; Juliano do Carmo (Organizadores)

Strawson \& Kant: Ensaios Comemorativos aos 50 anos de The Bounds of Sense Itamar Luis Gelain; Jaimir Conte (Organizadores)

A Filosofia Política na Idade Média

Sérgio Ricardo Strefling

Pensamento e Objeto: A Conexão entre Linguagem e Realidade Breno Hax
A Companion to Naturalism
Juliano do Carmo (Organizador)
Ciência Empírica e Justificação
Rejane Xavier
A Centralidade da Política Democrática: Ensaios Sobre Habermas Leno Danner

L'Éthique du Tractatus: Non-Sens, Stoïcisme et le Sens de la Vie Janyne Sattler

Michel Foucault: As Palavras e as Coisas

Kelin Valeirão; Sônia Schio (Organizadoras)

Acesse 0 acervo completo em:

www. nepfil.ufpel.edu.br 
(C) Série Dissertatio de Filosofia, 2017

Universidade Federal de Pelotas

Departamento de Filosofia

Núcleo de Ensino e Pesquisa em Filosofia

Editora da UFPel

NEPFil online

Rua Alberto Rosa, 154 - CEP 96010-770 - Pelotas/RS

Os direitos autorais dos colaboradores desta obra estão de acordo com a Política Editorial do NEPFil online e da Editora da UFPel.

Primeira publicação em 2017 por NEPFil online e Editora da UFPel.

Dados Internacionais de Catalogação

N123 A Mediação Imperfeita em Paul Ricoeur
[recurso eletrônico] Adriane da Silva Machado Möbbs
- Pelotas: NEPFIL Online, 2017.
190p. - (Série Dissertatio-Filosofia).
Modo de acesso: Internet
<http://nepfil.ufpel.edu.br>
ISBN: $978-85-67332-50-5$

1. Paul Ricoeur. 2. Mediação Imperfeita. 3. Ética I. MÖBBS, Adriane da Silva Machado

COD 162

\section{Editores da Série Dissertatio de Filosofia:}

Prof. Dr. João Hobuss | Prof. Dr. Juliano do Carmo

Confecção de Capa: Prof. Dr. Juliano do Carmo

Diagramação: Prof. Dr. Lucas Duarte Silva Imagem da capa: Vanderli Ribeiro

Para maiores informações sobre o NEPFil online, visite nosso site: www.nepfil.ufpel.edu.br 
Para minha filha Isadora, que pensou que nunca teria fim... 
"Em nós algo de Hegel venceu algo de Kant; mas algo de Kant venceu algo de Hegel, porque nós somos tão radicalmente pós-hegelianos como somos pós-kantianos. Na minha opinião é esta troca e esta permutação que estruturam ainda o discurso filosófico de hoje. É por isso que a tarefa é pensá-los sempre melhor, pensando-os em conjunto, um contra o outro, e um pelo outro" RICOEUR. CI, 1990, p.401. 


\section{Lista de abreviaturas}

As referências às obras de Paul Ricoeur constam abreviadas, conforme lista abaixo, inclusive quando a fonte é nota de rodapé ou de final de texto, as quais são acrescidas da indicação do ano da publicação da obra consultada e página (exemplo: RICOEUR. VI, 1950, p.15). Para artigos publicados em periódicos de autoria de Paul Ricoeur; obras e periódicos de comentadores e intérpretes, 0 sistema de citações segue o mesmo padrão normativo do documento MDT/PRPGP/UFSM e da ABNT.

VI Philosophie de la volonté 1 Le volontaire et l'involontaire

HF Philosophie de la volonté 2 Finitude et culpabilité 1, L'homme faillible

SM Philosophie de la volonté 2 Finitude et culpabilité 2, La symbolique du mal

HV Histoire et vérité

DI De l'interprétation, essai sur Freud

$\mathrm{Cl} \quad$ Le conflit des interprétations

MV La métaphore vive

TR1 Temps et Récit t.1 L'intrigue et le récit historique

TR2 Temps et Récit t.2 La configuration du temps dans le récit de fiction

TR3 Temps et Récit t.3 Le temps raconté

DA Du texte à l'action

AP À l'école de la phénoménologie

SA Soi-même comme un autre

L1 Lectures 1, Autour du politique

L2 Lectures 2, La contrée des philosophes

L3 Lecture 3, Aux frontières de la philosophie

RF Réflexion faite

CC La critique et la conviction (entretiens)

J1 Le juste

IU Idéologie et utopie

NR La nature et la règle, ce qui nous fait penser (avec J-P C hangeux),

MHO Mémoire, Histoire, Oubli

J2 Le juste 2

PR Parcours de la reconnaissance 


\section{Prefácio}

"A mediação imperfeita de Ricoeur não é mais uma autorreflexão do Absoluto, como pretendeu Hegel, pois ela pertence ao homem. Ela representa a saída da imediatidade da consciência através da mediação dela mesma, através de seu próprio esforço, da sua reflexão, ela é uma ação existencial. Ela é uma reflexão no sentido amplo - uma tarefa da consciência, um esforço do existir - e é nesse sentido que Paul Ricoeur busca mostrar o 'lugar' da dialética que, ao contrário da dialética hegeliana, não pretende ocupar todos os lugares, ou seja, não pretende abranger a totalidade, mas ao contrário, possui um lugar que está situado, em último sentido na práxis; mais precisamente, na realidade humana histórica", escreve Adriane Möbbs. E acrescenta: a acerca disso diz Ricoeur (1973, p.94): "[...] Minha tese é que se há um lugar onde as oposições produtivas podem ser observadas, reconhecidas e identificadas, este lugar é a realidade humana".

Negando ao conhecimento humano e, por conseguinte, à Filosofia a possibilidade de conhecimento Absoluto e à consciência a capacidade da imediatez, a autora, com esta passagem, nos conduz diretamente ao núcleo de sua obra e, diria mais, a uma das direções fundamentais da filosofia de Paul Ricoeur. Com efeito, interpretação, hermenêutica, símbolo, significado, sentido, reflexão, rastro, vestígio são termos recorrentes que perpassam a obra toda de Ricoeur e alertam deste 0 início o leitor sobre a proposta hermenêutica. Adriane Möbbs explorando, em sua pesquisa, o problema da mediação imperfeita, locomove-se na abordagem de uma das questões mais fundamentais do arcabouço filosófico da hoje chamada Filosofia Hermenêutica de Ricoeur.

Pode-se perguntar: Filosofia Hermenêutica para quê? O próprio Ricoeur, em Do Texto à Ação - Ensaios de Hermêneutica II nos responde: "Para uma teoria geral da interpretação". Mas com esta resposta avançamos pouco. Ainda seria preciso perguntar: Interpretar o quê e por quê? 0 próprio texto de Möbbs citado acima, nos oferece pistas para aprofundarmo-nos nestas duas últimas questões. A interpretação sob a forma de interpretação imperfeita se impõe para observar, reconhecer e identificar as "oposições produtivas" que ocorrem no mundo que é "a realidade humana". Assim, pode-se inferir que uma das tarefas da filosofia 
hermenêutica de Ricoeur pretende ser a interpretação da realidade humana ou, para usar uma expressão de François Dosse, é fazer aparecer a "questão do sentido da ação humana".

Este horizonte antropológico, presente em toda a obra de Ricoeur, norteia e fecunda o texto de Möbbs, quando incansável e incisivamente insiste que a mediação "esta num lugar privilegiado, a saber: na realidade humana" (p.126ss.). O texto da obra está estruturado em cinco capítulos.

No primeiro capítulo a autora tenta mostrar aspectos essenciais da vasta produção ricoeuriana, não tanto mapeando o que foi produzido, mas como mesma escreve, "demonstrar que a cada novo livro Paul Ricoeur parece preocupar-se com um novo problema...".

No segundo capítulo - Resistir à tentação hegeliana - a pesquisadora analisa a suspeita de Ricoeur em relação à imediatidade e apodicticidade dos filósofos da Consciência e a recusa da proposta hegeliana de uma "mediação total" e, consequentemente, de um saber absoluto. É notável a análise crítica que Adriane faz da "apologética hegeliana" de Jean Hyppolite, mostrando, ao mesmo tempo, a "sedução" que a filosofia de Hegel exerceu sobre a filosofia de Ricoeur.

Terceiro capítulo - A Mediação Imperfeita - situa o lugar da categoria central da tese, a saber: a Mediação Imperfeita. Esta nunca tem a pretensão de ser um saber absoluto, mas é interpretação. Várias passagens do capítulo mostram a proximidade e, ao mesmo tempo, o distanciamento em relação às filosofias da consciência, em geral, e do hegelianismo, em particular. O texto mostra que Ricoeur mantém o termo hegeliano de "Dialética" (Aufhebung). Ao mesmo tempo, mostra uma "diferença irredutível": "A interpretação é sempre uma função da finitude" (p.117). Na mesma página cita Ricoeur em Percursos do Reconhecimento: "Eu não posso me colocar como Hegel em um ponto onde eu veria o todo" (p.117). Na mesma direção - parentesco e distanciamento em relação à filosofia da consciência e o hegelianismo - o texto de Adriane vai elucidando progressivamente o significado de sua tese central, a "mediação imperfeita". "A dialética aberta, imperfeita, proposta por Ricoeur é uma dialética baseada no paradoxo, mas que busca a reconciliação e a alteridade. É uma dialética que busca a alteridade e a conciliação com o outro, mas sem uma síntese dialética total, sem a totalização" (p.122). 
E ainda: "Por isso, defendemos que o que há de mais singular na obra de Ricoeur é de fato a sua dialética, mais precisamente naquilo que ela propõe uma Mediação Imperfeita..." (p.126) e, complementa: "A mediação imperfeita de Ricoeur não é mais uma autorreflexão do Absoluto... pois ela pertence ao homem" (Ibid.). E conclui: "Portanto, para Ricoeur o lugar" da dialética da mediação... está num lugar privilegiado, a saber: na realidade humana" (p.126).

0 quarto capítulo aprofunda o estudo da tese central - A Mediação Imperfeita - em três momentos constitutivos: 1. Desejo racional e vontade: 2. 0 Espírito Subjetivo; 3. Da vontade subjetiva à vontade objetiva, tendo por ponto de partida o artigo de 1973: O Lugar da Dialética. O capítulo trata, primeiramente da "crise da noção de consciência" e rejeita a identificação entre sujeito e consciência. "É preciso perder a consciência para encontrar o sujeito". "A consciência não é imediata, mas mediata; ela não é uma fonte, mas uma tarefa, a tarefa de se tornar mais consciente" (p.144). Aqui aparece uma nova concepção de consciência e de sujeito, fecundada pelos estudos Ricoeurianos de Freud, já presentes desde 0 Conflito das Interpretações. Também é aprofundada a própria concepção de filosofia hermenêutica como filosofia reflexiva - "uma ligação dialética entre uma teleologia e uma arqueologia" (p.145).

Aqui se pode perguntar: é um confronto entre Hegel e Freud? É a proposição do diálogo? Ou é uma nova concepção de dialética? Na continuidade da pesquisa o texto trata da famosa discussão de Ricoeur com Derrida a propósito da metáfora, a partir das diferenças sobre a concepção de aufhebung em Hegel (p.153-167).

Ricoeur defende 0 aufheben como "conservar". Assim, a dialética teria por função "garantir a autonomia, a especificidade e os limites da filosofia, onde se desenvolvem os conceitos" (p.167). Aqui não estaríamos próximos dos "Mestres da suspeita", temática cara a Ricoeur nos anos 60 (C.I. 1969), quando trabalha o símbolo e a base da hermenêutica?

A parte final do capítulo trata da filosofia prática. A meditação sobre o lugar do conflito na vida moral privilegia o tema da tragédia, por nela se encontrar um apelo a "deliberar bem" e a "pensar justo". Discute a moral, o direito e 0 estado hegelianos e sugere que a proposta "ética de Ricoeur" é fundada no sujeito autônomo, que se reconhece como ser finito no mundo, capaz de interpretar e 
reinterpretar constantemente os valores explícitos e implícitos nas narrativas vivenciadas e recebidas e, em outro sentido, nascido agora de uma exigência moral, esse sujeito adapta e readapta sua escolhas e liberdades pessoais aos desafios presentes" (p.190).

O quinto capítulo - A não totalização da sua obra - apresenta duas interpretações relevantes da obra filosófica de Ricoeur: a de Domenico Jervolino e a de Marco Salvioli e marca a posição da autora em torno da questão de "um fio condutor".

Quanto à tese de Jervolino, a obra de Ricoeur pode ser vista como se desenvolvendo por fases, não necessariamente excludentes, mas marcantes. Escreve que pode se trabalhar com a hipótese de três paradigmas: símbolo, texto e tradução, numa linha histórica e hermenêutica da obra de Ricoeur (p.196). A tese de Salvioli sustenta a primazia da unidade da obra de Ricoeur em torno do símbolo: "O símbolo representa mais o fundo permanente embora não determinante nem último, do desenvolvimento de qualquer outro momento da filosofia da interpretação proposta por Ricoeur" (p.201).

A autora, apoiada em Ricoeur, encontra o "fio tênue, mas contínuo" que é o "homem capaz" (p.210).

Osmar Miguel Schaefer

Departamento de Filosofia Universidade Federal de Pelotas 


\title{
Apresentação
}

\author{
"A cet égard, j'aimerais parler plutôt d'une \\ spirale sans fin qui fait passer la méditation \\ plusieurs fois par le même point, mais à une \\ altitude différente" \\ Ricoeur, Temps et récit.
}

A mediação imperfeita em Paul Ricoeur é um texto que preenche uma carência na literatura que trata a obra deste filósofo francês. Também preenche um grande vazio deixado em filosofia pelos estudiosos da fenomenologia, da hermenêutica e da dialética. Sua originalidade consiste em mostrar que 0 pensamento de Ricoeur se articula em sua totalidade a partir da noção de mediação imperfeita. Além disso, que esta noção ricoeuriana é central tanto na releitura da fenomenologia e da hermenêutica, quanto da dialética hegeliana ou sua versão marxiana e marxista.

Se, por um lado, Ricoeur admite fazer um enxerto da fenomenologia na hermenêutica, não é menos verdade que a dialética é a seiva viva que corre entre as duas partes enxertadas. É esta vida que traz as marcas da finitude, da imperfeição e da própria mediação como algo nunca acabado, o que dá o contorno básico de um pensamento que sempre está em movimento, em questão, em via de realização, em busca de si.

Não é de admirar que o interlocutor privilegiado escolhido pela autora para tratar a vertente dialética apropriada por Ricoeur seja o próprio Hegel, pois é em torno dele se aglutina e estrutura grande parte da compreensão da herança dialética, e do próprio pensamento do filósofo francês. É curioso, no entanto, que ela acentue uma espécie de interdição no encontro de Ricoeur com Hegel. A dialética hegeliana, tal como foi proposta, torna-se um fruto proibido. Em vários momentos de sua obra Ricoeur fala da tentação hegeliana que consiste justamente em buscar uma mediação perfeita: a mediação alcançada como Saber que tudo sabe, uma Vontade absoluta, um Estado ético.

Para a autora, a ideia de mediação imperfeita também vai se afastar de uma filosofia do cogito, na tentativa de suprir as deficiências trazidas por uma 
concepção de consciência imediata, centrada em si mesma e autossuficiente. Assim, a mediação imperfeita não apenas rejeita uma mediação absoluta da consciência como de igual modo uma consciência sem mediações. Nos dois casos, a finitude é colocada em risco. A mediação perfeita paralisa a consciência, transformando-a em autoritária. A falta de mediação produz uma consciência ingênua, colada na imediaticidade. Uma consciência sem suspeita. Não tem ideologias, não reconhece conflitos de interpretações, não tem inconsciente. Depois de assumir a chamada hermenêutica da suspeita (Freud, Nietzsche e Marx), Ricoeur não poderá mais retroceder.

Ao lado disso, a noção de mediação imperfeita não poderá estar totalmente pronta. É preciso moldá-la para desempenhar uma nova função. Se, por um lado, o cogito cartesiano mostrava-se insuficiente por partir de um ponto de vista absoluto. Por outro, o problema trazido por Hegel reside em seu ponto de chegada: a mediação suspende a possibilidade de diálogo em um saber, uma vontade e uma instituição totais. Hegel é o convite para provar o fruto proibido.

A tese principal da autora é que a remodelação da noção hegeliana de mediação imperfeita por parte Ricoeur se dá em três momentos principais de sua vasta e entrecortada obra. Esses momentos são reunidos em torno do que ela denomina por três tentações hegelianas que Ricoeur tem de resistir. Sabe-se que, nas tentações bíblicas, do alto da montanha o diabo apresenta três alternativas para o Jesus dos evangelhos. Poderá ser um milagreiro que transforma pedras em pães, erradicando a fome da multidão. Poderá ser um político, liderando a luta contra o império romano. Poderá ser um sacerdote do templo, continuando a tradição judaica. A resposta já é conhecida. E como nas tentações bíblicas, Ricoeur também rejeita as três alternativas derivadas do pensamento hegeliano.

A primeira alternativa rejeitada é a do Saber absoluto que acaba eliminando a finitude, a própria possibilidade de mediação e, por fim, o indivíduo humano como sujeito do conhecimento. Com isso, Ricoeur também não cede às tendências contemporâneas de uma estrutura sem sujeito que, embora situadas ao nível discursivo, não são mais que réplicas do Espírito absoluto hegeliano ou mesmo do sujeito transcendental kantiano.

A segunda alternativa reside na vontade. Nega-se a possibilidade de uma ação guiada por uma vontade absoluta e autossuficiente. Aqui Ricoeur desabilitaria dois tipos principais de vontade. Uma vontade absoluta que elimina as vontades particulares, concretas, finitas. Uma vontade particular que não reconhece o peso 
do involuntário. 0 que está em jogo aqui é abrir a possibilidade de pensar o mal sofrido, haja vista que a modernidade só consegue pensar o mal praticado.

A terceira alternativa diz respeito às instituições. Aqui a releitura de Hegel aponta para as figuras do fim da história e do Estado como entidade ética por excelência. A utopia do fim da história como uma mediação perfeita, transforma-se em ideológica, conduzindo a uma paralisia da dialética. O Estado como entidade detentora da moralidade e do direito facilmente deságua nos regimes de terror. Nos dois casos, o que temos é a negação da dialética como uma mediação imperfeita.

A releitura de Ricoeur pela autora nos leva a pensar em uma dialética viva, não petrificada na esfera do saber, da vontade e das instituições. Uma dialética que está em todos os lugares e que não está em lugar nenhum.

Não obstante, em um segundo momento, como consequência da própria aplicação deste marco teórico, a autora vai reler algumas sugestões interpretativas da obra de Ricoeur. Alguns estudiosos entendem que a unidade da obra ricoeuriana se dá em torno do símbolo. Outros, ao contrário, afirmam que 0 símbolo é apenas um momento inicial, superado pelo texto, a narrativa ou a tradução. Da perspectiva da mediação imperfeita, essas buscas se mostram, no melhor dos casos, um reflexo das antigas sombras das mediações absolutas.

Do início ao fim, a autora se mantém atenta a duas reflexões principais. A primeira é que Ricoeur se utiliza da fenomenologia, da hermenêutica e da dialética para poder responder mais adequadamente as questões de nosso tempo. No entanto, em segundo lugar, é preciso entender com ele que se é pela hermenêutica que se consegue sair da fenomenologia pura, é pela dialética que se conseguirá romper com a tautologia e a violência no campo da interpretação. Só a dialética viva consegue transformar o círculo hermenêutico em uma espiral sem fim. É assim que, como nos mostra a própria autora ao final de seu texto, o caráter aparentemente fragmentário da obra de Ricoeur, é na verdade a aplicação de seu marco teórico: o texto é uma mediação sempre imperfeita, aberta, fragmentária.

Noeli Dutra Rossatto

Departamento de Filosofia Universidade Federal de Santa Maria 


\section{Nota da autora}

Este livro é o resultado de quatro anos de pesquisa acerca da categoria da mediação imperfeita na obra do filósofo francês Paul Ricoeur. Cabe ressaltar, que não tenho a pretensão de esgotar aqui as possibilidades de operar a categoria da mediação imperfeita. Pensar e articular essa categoria como um fio tênue que perpassa toda a obra de Ricoeur, está longe de limitá-la ou dar uma unidade à ela, ao contrário, o que me propus aqui é pensar o caráter fragmentário da obra ricoeuriana - já admitido pelo próprio Ricoeur, ao menos em dois momentos como a operação dessa categoria, que pretende ser aberta, fragmentária, imperfeita e, sempre articulada com o homme capable, mas nunca unitária, totalizante, perfeita. Por fim, procurei assegurar que a mediação imperfeita, aberta e fragmentária se mantém numa dialética ininterrupta que articula o si-mesmo com 0 outro e a identidade com a alteridade.

Portanto, com a consciência de que a tarefa apenas se inicia aqui, sustento a tese de que o pensamento ricoeuriano se articula com base na noção de mediação imperfeita, parcial e finita, principalmente em distinção à mediação de sentido hegeliana que se define em termos absolutos.

Sustentar tal tese implica, de um lado, em reconstruir alguns aspectos internos à obra de Ricoeur, notadamente o que qualifico como as três tentações hegelianas, a saber: a tentação do absoluto no Espírito, na História e no Estado. De outro modo, implica em examinar algumas teses que prescrevem soluções contrárias a minha. Uma delas é a tese que defende a unidade da obra de Ricoeur com base nos paradigmas do símbolo, texto e tradução; a outra é a que defende a unidade de sua obra em torno do símbolo. Contrariamente, entendo que símbolo, texto e tradução não são mais que diferentes formas de renunciar a toda e qualquer forma de mediação total.

Tal estudo não seria possível se não fosse o apoio financeiro da Capes, através da bolsa de estudos (DS) e da incansável disposição do meu orientador, o Professor Doutor Noeli Dutra Rossatto, a quem sou extremamente grata por sua disposição em apadrinhar esse projeto, por sua orientação competente e precisa e, principalmente, por seus conselhos.

Agradeço também aos amigos e pesquisadores de Paul Ricoeur: Paulo Gilberto Gubert, Cláudio Reichert do Nascimento, Maria da Penha Villela-Petit, 
Gonçalo Marcelo, Élsio Corá, João Botton, Adelson Simões e Roberto Lauxen, por terem me apoiado e contribuído de forma indispensável para este estudo.

Boa leitura! 


\section{Sumário}

Lista de abreviaturas

VII

Prefácio

Apresentação

XII

Nota da autora

XV

Introdução

1. Paul Ricoeur e seu caminho filosófico 23

1.1- Por uma fenomenologia da vontade $\quad 25$

1.2-O homem falível 28

1.3- A simbólica do mal 31

1.4- Da ação à linguagem 34

2. Resistir à tentação hegeliana 41

2.1- Primeira tentação: o retorno a Hegel 42

2.2- Segunda tentação: Hegel e a razão prática 53

2.2.1- A razão prática 53

2.2.2- A "regra de ação"

2.2.3- Se a razão, enquanto tal, pode ser prática 61

2.2.4- A tentação hegeliana 66

2.3- Renunciar a Hegel $\quad 76$

2.3.1- A terceira tentação hegeliana 81

2.3.2- A impossível mediação total na História 86

3. A mediação imperfeita $\quad 91$

$\begin{array}{ll}\text { 3.2- A consciência como tarefa } & 97\end{array}$ 
3.3- O paradoxo sem Aufhebung

3.4- O sentido de "conservar" da Aufhebung

3.5- A mediação imperfeita e a oposição produtiva

4. A mediação imperfeita em três momentos

4.1- Primeiro momento: desejo racional e vontade

4.2- Segundo momento: o espírito subjetivo

4.3- Terceiro momento: da vontade subjetiva à vontade objetiva

5. Ricoeur: a não totalização da sua obra

5.1- Paul Ricoeur a partir de três paradigmas

5.2- O símbolo como unidade da obra Ricoeuriana

5.3- Paul Ricoeur e o homem capaz

Conclusão

Referências

Obras de Paul Ricoeur

Referências secundárias 


\section{INTRODUÇÃO}

Após dez anos de sua morte, Paul Ricoeur (1913-2005) não deixa de suscitar discussões e reflexões acerca dos temas com os quais se preocupou, entre eles, destacam-se os problemas filosóficos, teológicos, científicos, entre outros. Difícil é a tarefa deixada por ele aos seus intérpretes: "estão vocês para continuar a obra, estão vocês". Diante de tantas obras e temas variados é difícil dizer com quais problemas filosóficos ele não se preocupou, pois dialogava com grande facilidade com grande parte dos filósofos, desde os antigos até os seus contemporâneos, e demonstrava grande familiaridade com seus textos e conceitos.

A nossa pesquisa intitulada $O$ problema da mediação imperfeita em Paul Ricoeur tem como escopo tratar o tema da mediação que aparece já em Le volontaire et l'involontaire (1950), e que, apesar de central, é um tema pouco investigado, o que acarreta na dificuldade inclusive de encontrar comentadores que 0 tratam. E ainda, a pouca literatura sobre o tema muitas vezes se limita à dupla mediação da temporalidade, ou mesmo à dialética entre explicar e compreender, que são, a nosso ver, apenas momentos da aplicação de seu marco teórico mais amplo, não caracterizando a totalidade de sua proposta de uma mediação imperfeita.

Neste sentido, o que pretendemos é demonstrar que o problema do imediato e do mediado, acompanhado da sua contrariedade em aceitar a imediatidade da consciência, conduzem Paul Ricoeur à questão da mediação. A mediação proposta pelo filósofo nos parece distinta da dialética de Hegel, uma vez que, ao menos em três momentos de sua obra, ele declara a necessidade de renunciar a Hegel. Contudo, não é possível admitir que Hegel não o tenha influenciado, quando o próprio declarou ser um "kantiano pós-hegeliano e um hegeliano pós-kantiano" (RICOEUR, Cl, 1969, p.401).

\footnotetext{
1 Paul Ricœur declarou, em um dos seus últimos pronunciamentos em Santiago de Compostela, em 2004: "no, no, mi muerte está prevista, pero no pasa nada, están ustedes para continuar la obra, están ustedes. Por tanto, no pasa nada si desaparece una u otra figura, porque al fin y al cabo, si una figura es significativa en el ámbito de la cultura, deja descendientes" (RICOEUR apud FAFIÁN, 2006, p.98).
} 
Nossa tese é a de que a busca de uma mediação imperfeita, caracterizada por uma dialética que se articula a partir de um si-mesmo voltado para o outro, atravessa a totalidade da obra de Ricoeur. Desde Le volontaire et l'involontaire (1950) até Parcours de la reconnaissance (2004) esta dialética está declinada nos termos de uma mediação imperfeita a qual não se deixa totalizar por um saber absoluto, tampouco é comandada pelos mecanismos de uma positividade imediata. Não obstante, a mediação imperfeita é tomada no sentido de um marco teórico utilizado pelo autor. É o seu método ou procedimento que está na articulação mais elementar, e às vezes inconfessada, de toda a reflexão filosófica que baliza sua obra. No entanto, a mediação imperfeita não pode se dar como uma unidade compacta, mecânica e sem vida, como nas modernas tentativas de sistematização filosófica, senão que se expressa como um "fio", às vezes quase invisível, que não conduz, mas demarca as condições de possibilidade de toda a discussão e de tratamento dos mais variados temas e problemas.

A resolução desta tese, de um lado, implica em ter de reconstruir alguns aspectos internos à própria obra do autor. A respeito da reconstrução interna da proposta de uma mediação imperfeita, nos detemos no que o próprio autor chama de "a tentação hegeliana" ou de "renunciar a Hegel". A rigor, são três as tentações hegelianas. Ao recusar três tendências, que na obra hegeliana conduziriam à mediação total, Ricoeur propõe em seu lugar uma dialética que habilita mediações imperfeitas, parciais, finitas; e que se deslocam não mais para a esfera do Absoluto, mas para o interior da práxis humana. E como tal, será sempre uma mediação que carrega consigo as marcas da finitude e que tem como fim a alteridade.

De outro lado, defender tal tese implica em enfrentar algumas soluções que não apontam na mesma direção que pretendemos seguir. A respeito destas soluções que não vão ao encontro da nossa, buscamos argumentar a partir do quadro teórico construído com base na ideia de mediação imperfeita. Desta perspectiva, acreditamos que não se sustenta a hipótese interpretativa de que Ricoeur desenvolve em sua obra três paradigmas que se alternam, a saber: o do símbolo, 0 do texto e o da tradução. 0 principal motivo para desestimar esta hipótese é que o símbolo, o texto e a tradução estão articulados propriamente como mediações imperfeitas, e não como mediações absolutas, que depois de algum tempo serão abandonadas ou substituídas. De igual modo, acreditamos não se sustentar a hipótese interpretativa de que toda a obra Ricoeuriana se articula com base no símbolo, pois, pelo mesmo motivo, também o símbolo se apresenta como uma das mediações imperfeitas, e não como a única mediação. 
Desta perspectiva, podemos ver com outros olhos alguns problemas e conceitos que preocuparam Ricoeur desde a sua juventude, e algumas posições que foram tomadas desde muito cedo. Como acontece com relação a sua contrariedade à imediatidade da consciência e à apodicticidade do Cogito cartesiano e do Eu penso kantiano, os seus questionamentos acerca da imediatidade da consciência the acompanharam por quase todo o seu percurso filosófico. Exemplo disso foi o seu relacionamento com os pensadores modernos, por ele denominada, "filosofia reflexiva" - de Descartes a Husserl -, com os quais teve uma aproximação e um distanciamento que começaram ainda na Universidade.

0 momento reflexivo the propiciou pensar acerca do retorno sobre si mesmo do sujeito, a busca por uma reapropriação de si, mas ao mesmo tempo, um distanciamento do cunho idealista e de certa forma subjetivista do primado da consciência. Paul Ricoeur discorda que a consciência seja origem ou fundamento, ele a compreende como tarefa, tarefa que requer um empenho constante de esclarecimento, esforço ou desejo de existir que se expressa na multiplicidade de operações do sujeito e dos sinais nos quais elas se objetivam.

Paul Ricoeur se aproxima de Husserl e do método fenomenológico, percebendo no tema da intencionalidade a possibilidade de romper com a identificação cartesiana entre consciência e consciência de si, e a possibilidade da consciência projetar-se para o exterior.

Sua primeira obra é um exercício fenomenológico acerca do tema da vontade, na qual irá tratar temas da esfera prática, tais como: o projeto, o hábito, a emoção e, pela primeira vez, o inconsciente. Todos esses temas foram tomados a partir da dialética entre o voluntário e o involuntário.

Após tratar do voluntário e involuntário, na primeira parte de Le volontaire et l'involontaire, Ricoeur se dedicará à finitude do homem numa antropologia que concebe o homem como ser finito. Nesta obra já se anuncia a 'virada hermenêutica' do filósofo, quando ele opera a dialética entre filosofia e nãofilosofia, captando conflitos e oferecendo mediações. Concebe o homem como ser finito e capaz de operar mediações, sempre em constante dialética.

0 presente estudo está dividido em cinco momentos. No primeiro, apresentaremos de forma sucinta o contexto em que emerge a problemática da mediação imperfeita, que é o objeto desta pesquisa.

No segundo momento, apresentamos os três passos que Paul Ricoeur trata acerca da necessidade de renunciar à tentação hegeliana, cujo objetivo é demonstrar o que o filósofo francês compreende como sendo necessário ser 
conservado de Hegel e o que é necessário renunciar. Procuraremos ainda elucidar a leitura Ricoeuriana de Hegel, no que ela compreende como sendo impossível conservar, como o Espírito Absoluto, por exemplo; e o tratamento destinado pelo filósofo francês ao hegelianismo, sobretudo nas releituras atuais, como a de Jean Hyppolite.

O terceiro momento consiste na apresentação da mediação imperfeita de Paul Ricoeur em sua tentativa de reconstrução da teleologia hegeliana, retomando as leituras atuais do filósofo alemão por parte de Jean Hyppolite e Derrida. Trataremos questões tais como: o que caracteriza e diferencia a sua dialética em relação à dialética hegeliana? Qual "lugar" de sua dialética? Que mediação é essa e onde ela se aplica? Para responder essas questões abordaremos quatro pontos que nos indicam o "lugar" da mediação proposta por Paul Ricoeur.

No quarto momento, apresentaremos os três momentos de operação da mediação imperfeita, conforme Paul Ricoeur estabelece em seu artigo Le "lieu" de la dialectique (1973). Neste capítulo traremos, ao menos, um exemplo de operação da mediação para elucidar cada um destes três momentos.

E, por fim, no quinto momento, traremos a discussão em dois intérpretes de Paul Ricoeur e suas respectivas teses acerca da unidade da obra do filósofo; e, portanto, as suas tentativas de totalização da obra do filósofo. Acreditamos ser necessário demonstrar que o caráter aparentemente fragmentário da obra de Ricoeur, é na verdade a aplicação de seu marco teórico, a saber: a mediação imperfeita, aberta, fragmentária. 


\section{1 \\ PAUL RICOEUR E SEU CAMINHO FILOSÓFICO}

Em 1995, com a publicação de Réflexion faite, uma autobiografia intelectual, Paul Ricoeur, se reconhece como contrário à imediatidade da adequação e à apodicticidade do Cogito cartesiano e do 'eu penso' kantiano. De acordo com o filósofo, a contrariedade está presente desde sua juventude. Como o próprio filósofo declara:

Hoje estou convicto de que devo ao meu primeiro professor de filosofia a resistência que opus à pretensão da imediatidade, da adequação e da apodicticidade do cogito cartesiano e do 'Eu penso' kantiano, ao passo que a continuação dos meus estudos universitários me tenha conduzido ao âmbito dos herdeiros franceses desses dois fundadores do pensamento moderno². (RICOEUR. RF, 1995, p.12-13, itálico do autor).

O questionamento acerca da consciência imediata de si acompanhará Ricoeur durante todo o seu caminho filosófico. $E$ a influência dos mestres, que ele chama de herdeiros franceses dos fundadores do pensamento moderno, explica 0 seu relacionamento com a tradição reflexiva moderna - de Descartes a Husserl -, que ele encontrará ainda na universidade.

A tradição reflexiva francesa é renovada por Jean Nabert, com sua obra L'experiénce philosophique de la liberté (1924), que exercerá grande influência em Ricoeur, principalmente nas décadas de 1950 e 1960. E, também, a fenomenologia

\footnotetext{
2 "Je suis aujourd'hui que je dois à mon premier maître de philosophie la résistance que j'opposai à la prétetion à l'immédiateté, à l'adéquation et à l'apodicticité du cogito cartésien, et du 'Je pense' kantien, lorsque la suite de mes études universitaires m'eut conduit dans la mouvance des héritiers français de ces deux fondateurs de la pensée moderne" (RICOEUR. RF, 1995, p.12-13, itálicos do autor).
} 
de Husserl, que ele ainda jovem descobrira entre os anos 1934-1935 em Paris, e que será por ele interpretada como uma variante da filosofia reflexiva do pensamento moderno (RICOEUR. RF, 1995, p.15-16).

A partir de seu contato com a tradição reflexiva francesa, Ricoeur cultivará a interpretação de que a filosofia possui um momento reflexivo - o retorno sobre si mesmo do sujeito, a busca por uma reapropriação de si - mas, também, tenderá a separar o método reflexivo da afirmação - de cunho idealista ou de algum modo subjetivista - do primado da consciência. Para ele, a consciência não é origem ou fundamento, mas tarefa, não é transparência, mas opacidade: requerendo um empenho constante de esclarecimento, de reunificação, para recuperar o esforço ou desejo de existir que se expressa na multiplicidade das operações do sujeito e dos sinais nos quais elas se objetivam (JERVOLINO, 2011, p.15-16).

Ricoeur afirmará sua visão com relação ao método fenomenológico de Husserl, ou seja, o método fenomenológico como um recurso inestimável para captar os fenômenos com toda a sua riqueza, mas salientando também suas reservas em relação aos desdobramentos idealistas presentes nos textos husserlianos da maturidade. Para Ricoeur, é na aproximação fenomenológica que estão presentes os elementos capazes de conectar uma dinâmica profunda que conduza a própria fenomenologia além do idealismo, ao rigor da interrogação e àquela que ele considera mais importante contribuição de Husserl, a saber, a intencionalidade da consciência.

É notório que o tema da intencionalidade em Husserl é capaz de romper a identificação cartesiana entre consciência e consciência de si; e revelar a consciência como projetada para o exterior, motivo pelo qual a fenomenologia husserliana é reconhecida na França na década de 1930.

É esta abertura ao real que permitirá ao jovem Ricoeur unir o interesse pela fenomenologia à orientação para o concreto e para um estilo filosófico de cunho existencial, proposto por Gabriel Marcel. O socratismo cristão e a filosofia da existência de Marcel - que também lhe introduz ao estudo de Jaspers -, se tornarão um corretivo para o intelectualismo da Sorbonne.

A primeira contribuição de Paul Ricoeur à filosofia, além das duas obras dedicadas ao pensamento dos seus primeiros mestres, Gabriel Marcel e Karl Jaspers $(1947,1948)$, é datada de 1950, com a publicação de Le volontaire et 
l'involontaire, consistindo num exercício de filosofia fenomenológica sobre o tema da vontade, no qual descreve os fenômenos fundamentais da esfera prática: 0 projeto, o hábito, a emoção e, também, pela primeira vez, o inconsciente, todos colocados sob o mesmo título de involuntário e voluntário absoluto, com a intenção de distingui-los das resistências e dos pontos de apoio que a vontade encontra ao nível da consciência dona de si.

\section{1- Por uma fenomenologia da vontade}

Parece-nos que aquele problema com o qual Ricoeur teve contato ainda na universidade, acerca da imediatidade, é uma das preocupações do filósofo ao repensar o método fenomenológico e a propor a vontade como tema de uma audaciosa pesquisa filosófica.

Em Réflexion faite (1995), Ricoeur revela que quando ingressou na Fenomenologia, a questão da percepção já havia sido tratada por Maurice Merleau-Ponty, e que pretendida dar a esse "grande livro" que é a Phénoménologie de la perception uma contrapartida de ordem prática (RICOEUR.RF, 1995, p.22-23). E deste projeto, nascerá sua Philosophie de la volonté, cujo primeiro tomo - Le volontaire et l'involontaire - foi publicado em 1950.

Desde então, é a dicotomia do agir e do sofrer que ocupa prioritariamente a atenção do filósofo, o que acaba repercutindo também na forma como ele encarara a fenomenologia de Husserl (VILLELA-PETIT, 2007, p.8).

Le volontaire et l'involontaire é um ensaio de "fenomenologia eidética", dedicado à descrição das estruturas essenciais ou eidéticas da vontade nos seus três momentos: a decisão, a moção voluntária e o consentimento (consentement). De acordo com Ricoeur, a análise parte do conteúdo (noema) mirado pelo ato da consciência (noese) para esclarecer o sentido deste último. A seguir, em cada nível da análise, o momento voluntário se encontra numa relação de reciprocidade com o involuntário e constitui seu princípio de inteligibilidade.

Para a fenomenologia de Ricoeur, ao contrário da psicologia empirista, é a compreensão do voluntário que vem antes dos elementos involuntários, ou seja, eu me compreendo antes de tudo como aquele que diz "Eu quero". Portanto, é a compreensão do caráter voluntário da vontade e do meu querer que antecipam o sentido; a necessidade, a emoção, o hábito entre outros, são solicitados, inclinados 
e, de certa forma, influenciados pela vontade. Acerca disso, diz Ricoeur (VI, 1950, p.8):

A necessidade, a emoção, o hábito etc. adquirem um sentido completo somente em relação a uma vontade que solicita, inclina e em geral influencia, e que de retorno estabelece o seu sentido, ou seja, determina-os mediante a sua escolha, move-os através do seu esforço e os adota mediante o seu consenso.

Contudo, não se trata de um fechamento em relação aos resultados da psicologia científica, uma vez que Ricoeur se caracteriza como um filósofo que dialoga com as ciências do homem. Há uma relação entre o corpo como objeto de conhecimento empírico e a corporeidade vivente no corpo-sujeito analisado pela fenomenologia, o que nos permite divisar um momento pré-hermenêutico já nessa primeira fase da obra Ricoeuriana (JERVOLINO, 2011, p.22).

Para Ricoeur, é possível e necessário que se aplique a distinção entre noema e noese - assim como Husserl havia começado a fazer - também à vontade e ao mundo dos afetos. Contudo, Ricoeur afirma:

Os resultados da extensão do método intencional à vontade devem ser direcionados contra a doutrina transcendental edificada sobre a base restrita da análise da 'representação' (ou seja, de todas as operações da consciência da qual a percepção constitui o modelo primário) (RICOEUR. AP, 2009, p.62, itálicos do autor).

Logo, no caso de uma volição ou de uma vivência afetiva não há exigência de que seu sentido seja preliminarmente conhecido, mas possuem um sentido por si mesmos. Toda e qualquer vivência por si mesma quer dizer algo, portanto, pode ser nomeada e compreendida. E não seria essa a aposta teorética da fenomenologia? Oferecer-nos um logos a todo fenômeno, sempre tomando cada um na sua peculiaridade, sem privilegiar uma entre as muitas modalidades do cogito. Ricoeur, retomando uma herança cartesiana, fala de um cogito integral:

A reconquista do cogito deve ser total, portanto, é no interior do próprio cogito que devemos encontrar o corpo e o involuntário que ele nutre. A experiência integral do Cogito inclui o eu desejo, o eu posso, o eu vivo e, em geral, a existência como corpo (RICOEUR. VI, 1950, p.13). 
Assim, a fenomenologia evita tornar-se a teoria de uma subjetividade reduzida a um mero ver, à qual todos os fenômenos remeteriam, uma subjetividade que seria o espectador desinteressado daquele grande espetáculo que se tornaria mundo (JERVOLINO, 2011, p.24).

Ao rejeitar a autointerpretação em sentido idealista da fenomenologia, como fora elaborada pelo próprio Husserl, a fenomenologia da vontade nos trará novas nuances à problemática de doação de sentido ou constituição transcendental. A vontade, de acordo com Ricoeur, é sempre um entrecruzamento entre o voluntário e o involuntário, e é nesse entrecruzamento que se projeta uma luz de inteligibilidade sobre o involuntário nas suas múltiplas manifestações (RICOEUR. $A P, 2009, p .73-74)$. É o que permite que eu assuma o involuntário como fonte da motivação das minhas decisões, como conjunto de poderes que são a condição das minhas ações, como situação concreta em que me encontro vivendo.

O caráter involuntário, quando assumido como contrapartida do meu querer, comporta o reconhecimento de um aspecto de passividade e de finitude humana e passa então da vontade que eu tenho à vontade que eu sou, que enquanto minha, uma vez que sou eu que me decido, coincide com a minha existência, com a minha corporeidade vivente. Portanto, nesse sentido, a vontade é primitiva e constituinte, sem deixar de ser finita.

O clássico dualismo metodológico entre alma e corpo é assim superado na reciprocidade do voluntário e do involuntário, a análise fenomenológico-existencial faz aflorar formas mais sutis de dualidade que Ricoeur chamará de "dualidade de existência". Tal dualidade de existência deve ser compreendida nas suas múltiplas manifestações antropológicas e éticas, da temporalização da existência como tensão entre o peso do passado e o impulso para o novo.

Logo, é possível perceber, diante da obra completa e complexa de Ricoeur, que ainda nos escritos jovens temos o preâmbulo, ou seja, o anúncio de temáticas que serão desenvolvidas nas obras mais maduras, como, por exemplo, a dialética do si e das suas múltiplas formas de alteridade de Soi-même comme um autre até La mémoire, l'histoire, l'oubli, onde tão explícita é a herança fenomenológica.

Portanto, a dialética entre o voluntário e involuntário, demonstra a condição humana da liberdade, para Ricoeur (AP, 2009, p.80), conforme ele assinala em $A$ l'école de la phénoménologie: "a liberdade é uma independência dependente". $E$, 
ele abordará esse tema também em sua obra Finitude et Culpabilité quando trata a questão do mal em La symbolique du mal (1960), principalmente quando trata 0 livre-arbítrio e o servo-arbítrio.

Embora o confronto com o inconsciente tenha ocupado o pensamento de Ricoeur longamente durante a década de 60 , este se dedicou a ampliar o campo de sua pesquisa sobre a vontade, examinando as experiências ambíguas que abrem para a vontade má e que geralmente são atribuídas a forças tenebrosas. Remete-nos a esse período o seu interesse pelas expressões simbólicas, míticas e poéticas, nas quais a humanidade inscreveu a sua experiência do mal moral.

\section{2-0 homem falível}

Na segunda parte da sua filosofia da vontade, Finitude et culpabilité, no volume intitulado L'homme faillible, - em um estudo de antropologia filosófica, com grande inspiração em Kant e Jean Nabert -, temos a concepção de homem, própria de Ricoeur, que está ancorada no sentido do limite, na finitude do humano e, no qual a reflexão é convidada a esclarecer a pré-compreensão do homem falível e, na sua expressão, do "patético da miséria" (JERVOLINO, 2011, p.33).

Para Ricoeur, esse pathos atinge a sua perfeição expressiva em alguma das expressões do mito e da retórica: no mito platônico da alma como mistura; na retórica pascaliana do homem situado entre dois infinitos, que antecipa de algum modo o conceito de angústia de Kierkegaard.

Como afirma Jervolino (2011, p.34): "A compreensão filosófica do paradoxo humano exige uma reflexão que perpassa sucessivas mediações", ou seja, para Ricoeur, a filosofia, a reflexão filosófica não é um começo, mas sim um recomeço, ela não inaugura a linguagem, mas parte e se alimenta de uma linguagem que é pré-filosófica, ou seja, a linguagem dos símbolos e dos mitos. E não é assim que ocorre quando a filosofia surge na Ásia Menor, no século VI a. C. ?! Uma linguagem grávida de pensamento. Os filósofos pré-socráticos, os "naturalistas" buscavam um princípio (arché) para explicar a origem do Cosmo (kósmos) e as causas dos fenômenos naturais; busca e explicações que os mitos tratavam de dar conta à época.

O que ocorre é que Ricoeur compreendera que a busca de sentido vem desde antes da filosofia e, por isso, interessou-se pelo metafórico, pelo narrativo e 
pelo poético e, de forma particular, pelas duas fontes - a bíblica e a grega - que marcaram 0 advento da civilização ocidental.

Aqui, já podemos perceber o germe da virada hermenêutica de Ricoeur, na sua dialética entre filosofia e não-filosofia, em sua capacidade de captar conflitos e procurar-Ihes as mediações. E, por isso, Ricoeur é capaz de afirmar que o homem é intermediário entre o ser sumo e o não-ser. Tendo em vista a concepção cartesiana de homem, ele diz:

O homem é intermediário não porque se encontra entre o anjo e a besta; mas o é por si mesmo, entre si e si; é intermediário porque é misto, e é misto porque opera mediações. [...] 0 seu ato de existir é o próprio ato de operar mediações entre todas as modalidades e todos os níveis da realidade fora dele e nele mesmo (RICOEUR. HF, 1982, p.27).

De acordo com o nosso autor, o homem opera mediações, está sempre numa dialética, por exemplo, ele [homem] é infinitude do discurso e perspectiva finita, necessidade de totalidade e restrição de caráter. $E$, como o infinito nunca é posse, essa mediação é sempre frágil. A síntese transcendental da imaginação oferecerá uma conexão para a reflexão sucessiva sobre a vida prática e a vida afetiva.

A afetividade é o terreno de realização existencial do ser paradoxal e conflituoso que é o homem. Desta forma, o que o autor faz é unir o transcendental, o prático e o afetivo, dando-nos assim, uma visão de conjunto do ser humano, 0 que se constitui como um prelúdio ao tema da fenomenologia hermenêutica do si, que será novamente abordado e aprofundado em Soi-même comme un autre.

Ricoeur chega à elaboração do conceito de falibilidade através da articulação entre três momentos dialéticos (que derivam da tríade kantiana das categorias da qualidade: realidade, negação, limitação), a saber: afirmação originária, diferença existencial e mediação humana. A finitude é própria do homem, enquanto ser racional finito; é a finitude frágil de um desejo e de um esforço para existir, na apropriação do limite e do empenho em operar mediações, tentando perigosa e problematicamente dizer sim à vida (JERVOLINO, 2011, p.37). Portanto, é a finitude de um homem que se reconhece finito, que se esforça para existir e que ao reconhecer seu limite, opera mediações, tentando dizer sim à vida. 
O sentimento então é aquele que revela a não coincidência entre si e si mesmo; ele é conflito e revela o homem como conflito originário; revela também que a mediação ou limitação é somente intencional, vista numa coisa ou numa obra, o que faz com que por si o homem sofra uma tensão (RICOEUR. HF, 1982, p.157).

A noção de conflito será tema central da primeira coletânea de ensaios de hermenêutica intitulada Le conflit des interprétations, publicada por Ricoeur ainda na década de 60. Nesta primeira fase de sua hermenêutica, da qual também faz parte o De l'interprétation - Essai sur Freud (1965) e os ensaios recolhidos no fim da década em Le conflit des interprétations (1969), à noção de símbolo como "expressão do sentido dúplice" é dado papel central, inclusive o filósofo irá definir o conceito de interpretação em função da noção de símbolo. De acordo com Ricoeur, é tarefa da hermenêutica filosófica compreender 0 conflito das interpretações e the oferecer uma mediação.

Nosso filósofo não se considera um crítico da Modernidade e, tampouco, um defensor do arcaico ou irracional, mas um pensador que compreende as tensões internas da Modernidade e busca reformular um conceito mais rico de razão. Para ele, trata-se de realizar "o enxerto hermenêutico" ${ }^{3}$ e, sem dúvida, este momento da compreensão das expressões de sentido duplo ou múltiplo do símbolo é um momento da compreensão de si. Para Ricoeur (Cl, 1990, p.13):

Mas o sujeito que se interpreta interpretando os sinais não é mais o cogito: é um existente que descobre, mediante a exegese da sua vida, que é posto no ser antes mesmo de pôr-se e de possuir-se. Assim a hermenêutica descobriria um modo de existir que comporia de alto a baixo um ser interpretado. Somente a reflexão, abolindo-se como reflexão, pode reconduzir às raízes ontológicas da compreensão.

Podemos perceber o "enxerto hermenêutico" proposto por Ricoeur, em sua análise dos símbolos e mitos do mal.

\footnotetext{
${ }^{3}$ Ricœur acredita que a fenomenologia seja insuficiente para a compreensão simbólica, uma vez que ela percebe o símbolo a partir do próprio símbolo, o filósofo propõe uma dialética entre hermenêutica e fenomenologia, o que ele chamará de enxerto hermenêutico na fenomenologia, ou seja, para compreensão do símbolo, se faz necessária uma articulação entre hermenêutica e fenomenologia.
} 


\section{3- A simbólica do mal}

Finitude et culpabilité (1960) marca a passagem para a fase hermenêutica do pensamento Ricoeuriano, uma vez que a realidade concreta do homem que se confessa culpado só pode ser captada mediante a interpretação de uma linguagem mítico-simbólica, como poderemos perceber no segundo volume da obra a Symbolique du mal, articulada com a primeira parte, na qual são estudados os símbolos primários do mal.

A obra possui três níveis: o dos símbolos primitivos do mal (as imagens fundamentais da culpa como a da queda, do pecado e da culpabilidade), depois 0 nível dos grandes mitos sobre a origem do mal (mito da criação, do trágico, da queda e da alma desterrada); e, finalmente, o das grandes especulações sobre as relações entre finitude e culpa.

De acordo com Ricoeur, no que diz respeito ao mal, sem a linguagem dos símbolos, o mal teria ficado na escuridão. Deste modo, é o estudo da linguagem dos símbolos primários ou primitivos que mais nos aproxima da experiência do mal.

É em La symbolique du mal que Ricoeur vislumbra que a única forma de compreender os mitos seria considerá-los como elaborações secundárias que remetem a uma "linguagem da confissão", - le langage de l'aveu -, por considerar que esta é a linguagem que fala ao filósofo sobre a culpa e o mal (RICOEUR. HF, 1982, p.14).

Para Ricoeur, a linguagem da confissão apresenta uma particularidade notável, que é o que resulta totalmente simbólico, quando se fala da mancha, do pecado e da culpabilidade. Portanto, compreender a linguagem da confissão equivale a desenvolver uma exegese do símbolo, a qual necessita de algumas regras para decifrá-los, ou seja, precisa-se de uma hermenêutica do símbolo (RICOEUR. HF, 1982, p.15).

É, contudo, a exegese dos símbolos primários - mancha, pecado e culpabilidade - que prepara a inserção dos mitos no conhecimento que o homem adquire sobre si mesmo.

Portanto, o homem pode ser identificado e caracterizado como um ser que pensa e, também, que cria explicações. É na tentativa de explicar a essência de todas as coisas e estabelecer uma ligação entre o compreensível e 0 
incompreensível, entre o físico e o metafísico, que inúmeras respostas foram elaboradas pelos homens, mediante a imaginação humana. Ricoeur compreende como mito ou narrativas secundárias aquelas repassadas nos textos e nos ritos sagrados de várias culturas.

Os mitos são o que Ricoeur chama de símbolos secundários e é necessário ter claro que eles não fazem parte de uma tentativa de escrever a história. Pelo menos é assim que são tratados no pensamento moderno: mito não tem a natureza causal explicativa da história. Contudo, é necessário ir com calma na distinção entre mito e história. Ela não pode levar até o ponto de desprezarem-se os mitos (FRANCO, 1995, p.68).

Ricoeur propõe que se veja o mito como mito, sem pretensão de história. Mas isso não significa que ele não considere o seu enorme poder elucidativo. Muito pelo contrário, é com o propósito de demonstrar o poder elucidativo do mito que Ricoeur propõe o seu estudo e sua compreensão como linguagem simbólica. O mito, para Ricoeur, é uma narrativa, e não uma explicação. Por isso que, para ser compreendido, o mito necessita ser interpretado.

O mito é pensado por Ricoeur, primeiramente, como um relato englobando toda a humanidade em uma narrativa exemplar. Ricoeur pensa 0 mito como movimento, tendo princípio e fim. Mas, para o autor, o fundamental é que o mito lida com o enigma da existência. Lida com a distância entre o homem idealizado e o homem real. Lida, também, com a distância entre a vida como se gostaria que ela fosse e como ela realmente é. Portanto, o mito é uma narrativa que possui uma universalidade concreta, que possui orientação temporal e procede a uma exploração ontológica (RICOEUR. HF, 1982, p.316-317).

Desta forma, os mitos do mal possuem a função simbólica de dizer o drama da existência humana, em suas várias formas: os mitos do início e do fim do mal, o mito da criação, o mito trágico, o mito da queda e o mito da alma desterrada. Os mitos do mal, enfim, tratam de modo simbólico de toda a experiência de dor que a vida carrega.

Acredita-se que o problema da vontade má e do mal obrigara Ricoeur a integrar o método fenomenológico de descrição das essências com um método de interpretação da tradição da filologia clássica, da exegese dos textos sagrados, da jurisprudência, posta sob o título de hermenêutica. 
Ricoeur propôs uma nova problemática na qual a passagem para a linguagem $e$ as suas grandes unidades de discurso constituídas pelos textos conferia a mediação entre a experiência viva e a reflexão filosófica. Esta problemática pode ser sintetizada nas duas fórmulas retiradas de seus textos daquela época, a saber: le symbole donne à penser e expliquer plus pour comprendre mieux. Sendo que a primeira fórmula concluía a filosofia da vontade; $\mathrm{e}$ a segunda, abria uma nova fase na obra do autor, estabelecendo uma relação de tensão entre duas aproximações opostas entre si: a explicação, que aproxima as ciências humanas das ciências da natureza, e a interpretação, que não se deixa determinar mediante a observação empírica, mas abre um espaço de discussão entre interpretações que competem entre si, aplicadas aos grandes textos da nossa cultura (RICOEUR, 2011, p.123).

Se L'homme faillible nos mostra a vontade como precária e vulnerável quando submetida às pressões do involuntário, ou seja, como incapaz de resistir a essas pressões, temos em La symbolique du mal uma associação entre ação e palavra, sob forma de imagem, que somente se abre quando o que se tem a dizer ultrapassa os recursos da linguagem conceitual. Os símbolos e mitos são as diversas expressões culturais, por meio das quais a ação humana é apreendida e julgada e, por isso, requerem interpretação.

É necessário compreender e interpretar o que os homens produzem em matéria de significação, numa tentativa de apreender o que dizem, como vivem e presenciam suas interpretações, daí a necessidade do enxerto hermenêutico (VILLELA-PETIT, 2007, p.8-9).

Talvez, numa visada retrospectiva, possamos ver aí o que conduziu Ricoeur a se interessar pelo pensamento de Freud e a ele dedicar uma obra (1965). É esta uma tentativa de investigar o problema da consciência levando em conta 0 involuntário, uma vez que ele tem uma dimensão que escapa à consciência.

Portanto, mais uma vez, temos a preocupação de Ricoeur com relação ao imediato, ou seja, o que ele pretende é tirar as consequências filosóficas do fato de que "os signos do homem" não possuem um único significado, um único sentido, uma significação única e de imediato manifesta, de forma que possam dispensar um trabalho de interpretação; ao contrário, eles necessitam da interpretação e da compreensão, ou seja, de uma dialética entre interpretar e compreender, conforme 
o próprio autor manifestou na La symbolique du mal e, também será abordada em Le conflit d'interpretation - Essais d'herméneutique I e depois em Du texte à l'acção - Essais d'herméneutique II.

Em sua obra De l'interprétation, essai sur Freud, o autor retoma sob um novo enfoque o problema deixado em aberto ao fim da La symbolique du mal, a saber, a investigação sobre a relação entre uma hermenêutica dos símbolos e uma filosofia da reflexão concreta.

0 ensaio sobre Freud marca o deslocamento deste problema mediante 0 avanço de seu trabalho como filósofo preocupado com o agir humano, ou seja, com a condição humana. Por isso, Ricoeur se dedica ao confronto entre interpretações rivais. Ele retoma em termos novos o problema do inconsciente, tratado de modo sistemático sob o título de involuntário absoluto na sua filosofia da vontade. Neste sentido, o retorno do inconsciente é marcado, não mais pelo seu caráter involuntário, mas como portador de um sentido a ser decifrado seguindo a dupla linha de explicação em termos de pulsão e da interpretação em termos de sentido duplo, como se vê no sonho, nos sintomas, nos lapsus, nas expressões míticas e poéticas (RICOEUR, 2011, p.123-124).

\section{4- Da ação à linguagem}

A partir disso, Ricoeur procurou um guia apropriado para o funcionamento complexo da linguagem: e, assim, se deslocou progressivamente de uma filosofia da ação para uma filosofia da linguagem, antes que uma espécie de movimento pendular o reconduzisse ao campo prático (RICOEUR, 2011, p.125). Logo, sem perder a sua pertença ao movimento fenomenológico e hermenêutico, 0 autor concentra-se no aspecto criativo da linguagem, se dedicando ao seguinte problema: como se formam as novas significações? Que, de acordo com ele, poderia ser denominado o problema da imaginação semântica ${ }^{4}$.

Contudo, parece-nos que não houve um deslocamento progressivo da filosofia da ação para uma filosofia da linguagem e, sim, uma ampliação do

\footnotetext{
${ }^{4}$ Aqui, Ricœur entende por imaginação não a representação mental de uma experiência perceptiva anterior, mas a esquematização de uma regra inteligível, à maneira do famoso "esquematismo" do intelecto, segundo Kant (RICOEUR, 2011, p.125).
} 
problema, uma vez que o agir humano é inseparável da produção de sentido através da linguagem; portanto, não há deslocamento, o problema ainda permanece o mesmo, é apenas ampliado, e irá remeter Ricoeur à história e, consequentemente, à narração, que serão temas de estudos futuros do autor como Temps et récit (1983-1985) e La mémoire, l'histoire, l'oubli (2000), os quais abordaremos mais adiante.

No vasto campo do imaginário semântico, o nosso autor delineou dois âmbitos bem delimitados: de uma parte, a formação da linguagem poética na esteira das expressões metafóricas; de outra, a formação da linguagem narrativa na esteira da linguística estrutural aplicada à narrativa. No seu livro La métaphore vive (1975), o autor percorreu um caminho histórico que começa com a retórica e a poética de Aristóteles, passa pela retórica dos Antigos e dos Modernos e desemboca nas mais sofisticadas análises da combinatória semiótica. E, por fim, se aventura numa exploração em direção à ontologia. De acordo com Ricoeur, "a linguagem poética, ao criar metaforicamente um novo sentido proposicional e discursivo, não descobre acaso regiões da experiência humana que podem ser acessiveis somente à linguagem analógica acoplada com a linguagem apofática (que nos diz aquilo que o ser não é): o 'ser como' no qual a metáfora deposita seu gênio?" (Ibid., p.126). Estas questões foram deixadas em suspenso pelo autor, para que ele pudesse se dedicar a outro foco de inovação semântica: a narrativa.

Neste sentido, Ricoeur tomou como guia a teoria aristotélica do enredo (o mythos, a trama narrativa) na Poética e formou, com a ajuda da narratologia contemporânea, o conceito de "configuração narrativa" numa tentativa de prestar contas das inumeráveis maneiras de combinar juntos no enredo os eventos, os personagens e as ações. E, assim, sobre a base de tal estrutura fundamental, explorou os grandes campos de experiência da narratividade: a conversação ordinária, a história dos historiadores, a ficção dos trágicos gregos e do romance, a utopia dos sonhadores políticos.

Ao mesmo tempo, abriu-se um caminho de acesso interessante ao problema do tempo: uma vez que a narrativa desenvolve um enredo no tempo; mais precisamente, ela expressa o tempo da ação e da paixão, o tempo dos acontecimentos e o dos sentimentos, construindo um tempo de segundo nível: 0 tempo que o enredo desdobra entre um início (da narrativa) e um fim (a conclusão 
ou não conclusão). Assim, essas estruturas temporais oferecem uma base ao que Ricoeur chamou de "a identidade narrativa dos indivíduos ou das comunidades" (Ibid., p.127).

A identidade narrativa difere da identidade biológica - que é marcada pelo código genético de cada um, que é formada nos primeiros meses de gestação, e por outros traços individuais - e, que não tem outra continuidade a não ser de uma história de vida. A narrativa, segundo Ricoeur (Ibidem.), "expressa o "quem" da ação e a única forma de permanência que convém à identidade narrativa não pode ser senão a de uma promessa, graças à qual eu me mantenho na constância de uma palavra dada e mantida". A narrativa, além das suas armadilhas, seus usos e abusos, suas caricaturas - como se pode perceber com relação aos povos e as nações, em que ela oferece uma cobertura ao medo, ao ódio, à violência, à autodestruição - possui, também, outras funções, tais como: é o instrumento linguístico que contribui para coordenar o tempo cósmico, o das mudanças naturais, e o tempo psicológico da memória e do esquecimento. Sabe-se que as estruturas narrativas, como nos apontou Ricoeur, inscrevem o tempo psicológico vivido nos ritmos da mudança física - através dos instrumentos de medição: relógio e calendário. "A narrativa é o grande comutador de sentido que opera em todos os níveis da realidade. E é obra de linguagem, empreendimento de inovação semântica" (cf. Ibid., p.128).

Após a publicação dos três volumes de Temps et récit, em, 1986, em virtude das Gifford Lectures na Universidade de Edimburgo, colocou-se a Ricoeur o problema de encontrar certa unidade - se não sistemática ao menos temática de sua obra, neste momento à distância de quarenta anos das suas primeiras publicações. Acerca disso, o autor diz:

A questão para mim era muito mais crítica pelo fato de eu - muito mais do que meus leitores - me sentir atingido pela diversidade dos temas enfrentados. De fato, cada livro nascera de determinado problema: a vontade, o inconsciente, a metáfora, a narrativa. De certo modo, eu creio numa espécie de dispersão do campo da reflexão filosófica em função de uma pluralidade de questões determinadas que exigem cada vez mais um tratamento diferenciado em vista de conclusões limitadas, porém exatas. Deste ponto de vista, não lamento ter dedicado a maior parte da minha obra a indagar a questão ou as questões que delimitam um espaço finito de 
interrogação, salvo ter reaberto a cada vez a pesquisa num horizonte de sentido que, em compensação, exercia a sua função de abertura somente às margens do problema tratado (RICOEUR, 2011, p.128).

Embora contrariado, Paul Ricoeur é instigado a propor uma chave de leitura para seu público e desse desafio nasceu Soi-même comme un autre (1990). Portanto, o autor reagrupa as múltiplas questões até então tratadas em um núcleo central que surge no nosso discurso por meio do uso que fazemos do verbo modal "eu posso". ${ }^{5}$ Assim, a obra está organizada em torno de quatro usos principais do "eu posso". Eu posso falar, posso agir, posso narrar, posso considerar-me responsável por minhas ações, permitir que me sejam imputadas enquanto verdadeiro autor. Nesse sentido, essas questões permitiram a Ricoeur abordar, sem confundi-las, as problemáticas relativas respectivamente à filosofia da linguagem, à filosofia da ação, à teoria narrativa e, finalmente, à filosofia moral. Cada um desses estágios foi subdividido por duas aproximações, uma analítica e uma reflexiva.

Observe que a preocupação de nosso autor é algo singular em sua trajetória, ou seja, quando impelido a dar uma resposta aos questionamentos acerca da unidade de sua obra, temos como resposta a publicação de Soi-même comme un autre. Portanto, temos a reunião das mediações do homme capable, o qual se diz de várias maneiras.

Nesta obra, no que se refere à linguagem, o autor dedicou-se, num primeiro capítulo, às aproximações estruturais da língua francesa e às aproximações "analíticas": referia-se ao modelo dessa aproximação objetiva, externa, onde 0 sentido semântico ou estilístico é independente de qualquer envolvimento subjetivo. Um capítulo foi dedicado à aproximação reflexiva graças às pesquisas contemporâneas sobre os atos discursivos (ou linguístico), como a promessa, a ordem, ou também a asserção - que, nem por isso, exige um empenho menor por parte do sujeito em relação à promessa e à ordem: um "eu creio que...", "eu posso afirmar que...", é subjacente a mais simples asserção relativa a um estado de coisas dado. Logo, essa correlação entre aproximação analítica e aproximação

\footnotetext{
${ }^{5}$ Este caminho fora explorado anteriormente por Merleau-Ponty, em sua obra: Phénomenologie de la perception (1945).
} 
reflexiva, ao nível da linguagem, pôde servir de modelo para uma correção semelhante nos outros campos do itinerário de pesquisa de Ricoeur.

Com relação ao poder agir, por um lado, Ricoeur enfrentou a teoria da ação no seu aspecto objetivo, coligando assim a ação do evento que se realiza no mundo físico e que deriva de uma causalidade psíquica observável e, por outro, seguiu o percurso do processo de interiorização que da ação-evento conduz à ação-projeto, e da causalidade observável à motivação vivida. Portanto, um conceito de "capacidade de agir" conferiu ao "eu posso" prático uma estrutura ao mesmo tempo objetiva e reflexiva.

No que tange ao "poder narrar", nosso autor integra os resultados dos seus trabalhos anteriores sobre a narrativa no vasto âmbito das capacidades humanas. $\mathrm{E}$, ao mesmo tempo, reencontra a aproximação objetiva do estruturalismo das décadas de 60-70 e da filosofia reflexiva com o conceito de identidade narrativa a sua expressão verbal apropriada.

Naquilo que se refere ao quarto emprego principal do verbo modal "eu posso", Ricoeur encontrou a sua exata formulação no conceito de imputabilidade; e isto Ihe permitiu aliar a esfera moral à esfera prática das capacidades humanas. 0 conceito de imputabilidade refere-se à capacidade de prestar contas das suas próprias ações, ou seja, o ser humano é capaz de assumir a responsabilidade pelas próprias ações, de prestar conta a si mesmo e aos outros, e dessa forma, considerar-se o seu verdadeiro autor. Neste sentido, apenas as ações cuja causalidade possa ser imputada a sujeitos responsáveis podem ser qualificadas moralmente como permitidas ou proibidas, boas ou más, justas ou injustas.

Ainda em o Soi-même comme un autre abriu-se outra possibilidade. Além daquela originada entre a aproximação analítico-objetiva e a aproximação reflexivo-subjetiva, isto é, a possibilidade derivante do desdobramento entre o si e o outro, surge uma terceira. Acerca dela nos diz Ricoeur (2011, p.131-132): "a própria noção do si me parecia distinguir-se da do eu não só por seu caráter reflexivo indireto, sublinhado em cada etapa pela mediação da linguagem, mas por seu caráter dialógico". Portanto, o "eu penso" é em primeira instância 0 pensamento de um "eu" e de um "tu", de um "nós". Na sua forma mais elementar, a da frase, o discurso consiste no fato de que alguém diz algo a um outro acerca de algo considerado como o referente comum, ou seja, o discurso é dirigido a... 0 
mesmo tipo de estrutura dialógica se deixa discernir no plano da ação: a ação é ação com..., ação contra... (Idem). E, são as narrativas que conferem à experiência moral o caráter de singularidade, assim como o de exemplaridade da sua configuração. Neste sentido, não apenas a experiência do tempo é "refigurada" pelas configurações narrativas, mas também a experiência moral, sob o signo do que mais tarde Ricoeur chamou de "sabedoria prática".

Lembrando ainda que os três últimos capítulos de Soi-même comme un autre são dedicados à experiência moral, que posteriormente será submetida a uma revisão importante, em sua obra Le Juste 1, embora 0 autor vá estendendo-a a múltiplos campos de aplicação (Ibid., p.133).

No ano de 2000, Ricoeur publica sua obra intitulada La Mémoire, l'histoire, l'oubli, que se originou da descoberta e do exame de questões residuais deixadas sem solução numa obra anterior - neste caso, Temps et récit - na qual a experiência temporal era diretamente confrontada com a atividade narrativa, sem considerar a mediação exercida entre uma e outra pela memória. Essa mediação operada pela memória ocultava um enigma que ficava não apenas sem solução, mas até não reconhecido. Esse enigma era 0 da presença na mente de uma imagem das coisas passadas e já ausentes. Logo, o enigma da presença da ausência resume todas as dificuldades inerentes ao exercício da capacidade da recordação. Neste sentido, 0 ato de poder fazer memória se acrescentou à lista dos poderes característicos daquilo que o autor chamou de "l'homme capable".

A experiência do reconhecimento, por sua vez, pode ser considerada como o critério no qual se atesta a capacidade da memória de representar o passado. Logo, neste momento do reconhecimento encontram-se as três problemáticas da memória, da história e do esquecimento. Desta forma, a memória que culmina nessa forma suprema do reconhecimento não é apenas reconhecimento de uma coisa passada, mas também reconhecimento de si mesmo.

A ligação entre a memória e o si foi considerada por Ricoeur como o critério por excelência da identidade pessoal, extensiva a todas as formas de identidade comunitária. Logo, o autor encontrou no percurso da memória a noção de identidade narrativa elaborada como conclusão de Temps et récit, que já se encontra enraizada na experiência mnemônica. 
A última obra que Ricoeur publica em vida é Parcours de la reconnaissance (2004), cuja origem é a constatação de uma contradição na constatação de uma ausência de uma teoria do reconhecimento na história das doutrinas filosóficas. Teria de haver uma teoria do reconhecimento comparável e com igual coerência à do conhecimento, de tal forma que, no plano lexicográfico, fosse possível colocar sob um único verbete do dicionário a variedade das acepções do termo "reconhecimento", existente na prática da linguagem ordinária. A obra traz em primeiro lugar a progressão da temática identidade, depois a acompanha a temática da alteridade; e, por fim, como pano de fundo mais dissimulado, temos a dialética entre reconhecimento e desconhecimento (RICOEUR. PR, 2006, p.260261).

A nossa intenção aqui, com este breve esboço da vasta obra de Paul Ricoeur, fora destacar aqueles aspectos que estão mais intimamente ligados com o nosso objeto de pesquisa; e, que, acreditamos, poderiam trazer importantes contribuições ao tema.

A abordagem realizada neste capítulo é bastante sintética, tendo em vista 0 quão vasta é a produção filosófica do autor. Contudo, muito mais que realizar um mapeamento de tal produção, pretendeu-se demonstrar que a cada novo livro, Paul Ricoeur parece preocupar-se com um novo problema, o que parece dar 0 caráter fragmentário de sua obra, ao qual alguns comentadores se referem. É notório que em várias de suas obras 0 autor menciona a sua incredulidade a questão da imediatidade e apodicticidade da consciência e do "Eu posso" kantiano, bem como sua dificuldade em aceitar Hegel e a sua pretensão de uma mediação total. É essa recusa à mediação totalizante de Hegel, como saída da imediatidade do Cogito e da apodicticidade do "Eu posso" que nos ocuparemos no capítulo seguinte. 


\section{RESISTIR À TENTAÇÃO HEGELIANA}

A resistência em aceitar a ideia da imediatidade da adequação e da apodicticidade do Cogito cartesiano e do "eu penso" kantiano, que como mencionamos no capítulo anterior, marcou significativamente a filosofia de Ricoeur, desde sua juventude, aliada ao fato deste filósofo reconhecer o momento reflexivo da filosofia (retorno sobre si mesmo do sujeito, busca por uma reapropriação de si) e, ainda, que ele tenderá a separar o método reflexivo da afirmação idealista/subjetivista do primado da consciência, nos permite perceber que a consciência é tomada por ele, não como origem ou fundamento, mas como tarefa.

Não obstante, essa tarefa, essa consciência, como a compreende Ricoeur, é um empenho constante de esclarecimento, de reunificação para recuperar 0 esforço ou desejo de existir. Tal empenho se expressa na multiplicidade das operações do sujeito e dos sinais, nos quais a consciência é objetivada.

Portanto, somos inclinados a pensar que dessa investigação, que tem como pano de fundo o mediato e o imediato, Ricoeur chegará à mediação imperfeita, não numa mediação total como pretendia Hegel, não àquela mediação que nega a figura de uma consciência para outra consciência, como a da dialética do Senhor e do Escravo, mas uma mediação imperfeita, aberta, que nos conduzirá, ao menos, a duas questões importantes, a saber: (1) à questão antropológica e, (2) a compreensão de si enquanto sujeito.

Neste sentido, analisaremos os três excertos das obras de Ricoeur, nos quais o autor apresenta suas razões para uma renúncia a Hegel e quais os motivos da sua preocupação com essa tentação. Dito isso, cabe ressaltar que 
optamos por abordá-los em ordem cronológica, considerando a data da sua primeira publicação. Portanto, na seção seguinte, abordaremos respectivamente: Retour à Hegel (1955) ${ }^{6}$, La tentation hégélienne $(1979){ }^{7}$, Renoncer à Hegel em Temps et Récit T3 - Le temps raconté (1985).

\section{1- Primeira tentação: o retorno a Hegel}

No texto intitulado Retour à Hegel (1955) que compõe Lectures 2, La contrée des philosophes (1992) Ricoeur anuncia já no primeiro parágrafo: "sempre se disse que o alvo da filosofia é o homem" (RICOEUR. L2, 1996, p.133), ou seja, uma antropologia filosófica. Talvez, por isso, Ricoeur tenha começado seus primeiros ensaios e escritos filosóficos justamente com a partir de uma antropologia filosófica, por compreender que o objeto da filosofia é o homem.

Esse seria 0 ponto comum entre a fenomenologia e as demais teorias, a saber: a visada "humanista". Mas a Filosofia Contemporânea discorda, uma vez que para ela a verdadeira questão que a filosofia busca responder é a do ser.

O que temos então é o que poderíamos chamar de duelo entre a antropologia e a ontologia. E um retorno a Hegel - não apenas ao Hegel da Fenomenologia do Espírito e da Filosofia do Direito, mas ao Hegel da Lógica -, conforme anuncia Paul Ricoeur, seria um sinal, dentre outros, dessa promoção da ontologia contra o primado da antropologia (RICOEUR. L2, 1996, p.133-134).

Portanto, Ricoeur se propõe nesse texto, a saber, se o homem - sua subjetividade e sua história objetiva - poderá ser algo mais que resíduo aos olhos dos filósofos que começam a pôr entre parênteses, a "suspender" o homem. Parece-nos que a preocupação deste filósofo é que, a subjetividade do homem e sua objetividade - ou seja, sua história objetiva -, possam ser esquecidas por aqueles que se dedicam apenas à ontologia.

Desta forma, Ricoeur nos traz a obra de Jean Hyppolite, Logique et existence - Essai sur la logique de Hegel (1953), primeiramente, porque, como ele

\footnotetext{
6 Publicado pela primeira vez em: Philosophie et ontologie; Revue Esprit, n8, (II.A.70); publicado pela segunda vez em Lectures 2, La contrée des philosophes (1992).

7 Publicado pela primeira vez em: La raison pratique; La rationalité aujourd'hui (II.A.344a); publicado pela segunda vez em Du texte à l'action (1986).
} 
próprio menciona, há várias maneiras de voltar a Hegel ou de partir dele, mas a mais insólita, com propósito humanista, é a que aborda Hegel pela Lógica e não pela Fenomenologia do Espírito.

Embora existam várias formas de voltar a Hegel ou mesmo partir dele, como reafirma Ricoeur, o mais inusitado, digamos assim, é que alguém o pretenda fazer com propósito humanista a partir da Lógica ${ }^{8}$, como se propõe Jean Hyppolite. O mais natural seria que se abordasse a Fenomenologia do Espírito, uma vez que essa é considerada a epopeia do homem através da sequência das figuras que constituem a história ideal da consciência e da consciência de si.

O que Jean Hyppolite faz é situar o leitor diante da pretensão abrupta de um saber absoluto, um saber que não contém mais seu objeto fora de si, além de si, mas um saber que se desenvolve como discurso e percorre as próprias articulações do ser: "então o discurso que o filósofo faz sobre o ser, é o próprio discurso do ser através do filósofo" (RICOEUR. L2, 1996, p.135). Portanto, o discurso do ser, nada mais é que o próprio discurso feito pelo ser do filósofo.

Observemos a argumentação de Hyppolite:

A invenção dialética não é outra coisa que o descobrimento do ser; não é uma construção mais ou menos arbitrária; a demonstração dialética se confunde com a realidade que se interpreta e se reflete a si mesma numa linguagem cheia de sentido. 0 prefácio da Fenomenologia, quiçá a mais bela exposição da filosofia hegeliana, dá sobre esse ponto, indicações tão densas como significativas. O objeto próprio da filosofia, diz Hegel, é a realidade efetiva [Wirklichkeit], esta categoria da Lógica que designa a unidade concreta da essência e da aparência, esta manifestação em que só se manifesta ela mesma e que não experimenta sua necessidade de uma

\footnotetext{
${ }^{8}$ Para Hegel, a "lógica" é a própria filosofia, a organização da fala, do discurso, do Logos que esgota todas as possibilidades do ser. Com ele, as categorias falam da própria ordem do absoluto. Essa revolução no problema das categorias tornou-se possível com a introdução, na ordem das categorias, do princípio de negatividade que Hegel utilizou em sua descrição das figuras fundamentais do Espírito. As categorias começam a mover-se; elas procedem por antítese e síntese; esse movimento é o desdobramento eterno no Absoluto. Assim, a Lógica é a própria ontologia, não mais como mistério, mas como discurso (RICOEUR. L2, 1996, p.135).
} 
inteligibilidade separada, senão em seu próprio movimento e desenvolvimento?.

E a linguagem humana que corre atrás de seu objeto, aqui repousa em si mesma. Portanto, como movimento do que é, ela é, e repousa em si mesma, ou seja, o movimento da linguagem é ela mesma. Pode-se dizer que o objeto da linguagem, aqui, é a própria linguagem.

Portanto, ao tomar a Lógica hegeliana, como ela se apresenta, ou seja, como explicação do absoluto através dos seus momentos dialéticos, Paul Ricoeur tentará explicar o que poderia ser a proposta de Jean Hyppolite, a saber: o Ensaio sobre a lógica de Hegel.

Para compreender a Lógica de Hegel, não podemos resumi-la, é necessário compreender cada categoria e pensá-la até o fim e, portanto, é necessário que se compreenda todo o sistema hegeliano, de forma que não é possível que se encurte o caminho, pois se corre o risco de reduzi-la, conforme Ricoeur: "a uma mecânica colada sobre um conteúdo estranho, ou de afastar de si a obra completa, tornada transcendente ao resumo que o historiador escreveria nas suas margens" (L2, 1996, p.135).

Não se pode falar sobre o sistema sem que o esteja operando. Portanto, até poderíamos aceitar, como esclarece Ricoeur, um Ensaio sobre a lógica de Hegel, que nos inserisse no sistema através da história da filosofia. $E$, sobre isso, temos a afirmativa de Ricoeur (Ibid.): "não há uma sequer das categorias do sistema que já não tenham sido postas em ação na filosofia pré-hegeliana", ou ainda, Ricoeur parafraseando Leibniz: "não há nada no sistema que antes não tenha estado na história, a não ser o próprio sistema" (Ibid.).

${ }^{9}$ Cf. HYPPOLITE, 1987, p.10: "La invención dialéctica no es otra cosa que el descubrimiento del ser; no es una construcción más o menos arbitraria; la demostración dialéctica se confunde con la realidad que se interpreta y se refleja a sí misma en un lenguaje lleno de sentido. El prefacio de la Fenomenología, quizá la más bella exposición de la filosofía hegeliana, da sobre este punto indicaciones tan densas como significativas. El objeto propio de la filosofía, dice Hegel, es la realidad afectiva [Wirklichkeit], esta categoría de la Lógica que designa la unidad concreta de la esencia y de la apariencia, esta manifestación en la que sólo se manifiesta ella misma y que no experimenta su necesidad en una inteligibilidad separada, sino en su propio movimiento y desarrollo". 
Parece-nos que Ricoeur quer demonstrar que é possível, como ele mesmo afirma, "repetir" a lógica de Hegel, fazendo uma recapitulação de toda a história da filosofia, seguindo a mesma ordem que fora proposta por Hegel em seu sistema, de forma que a história do pensamento nasceria e morreria no próprio sistema hegeliano, como se Hegel não fosse nada mais que um intérprete do eterno pensamento da história. Mas Ricoeur afirma que embora essa seja uma via possível, não é a escolhida por Jean Hyppolite, talvez porque ela possua o inconveniente de acabar por perder-se na erudição; afinal essa busca sem fim pelas origens históricas acabaria por fragmentar o sistema.

Agora se pretende demonstrar qual foi a tentativa realizada por Hyppolite, uma vez que a partir de Ricoeur, nos foi possível dizer o que Hyppolite não fez,. Para Ricoeur (L2, 1996, p.136), o que Hyppolite tentou está próximo de uma apologética hegeliana. Ele se apoiou nas experiências e operações humanas, numa série delas, como, por exemplo, falar, refletir, negar e anunciar, e se esforçou em demonstrar que é necessário pressupor que em cada uma há a identificação do pensamento e do ser, ou seja, é necessário pressupor a identificação do sentido e da coisa, portanto, o "saber absoluto". A tese de Hyppolite é a de que "uma fenomenologia (ou descrição fundamentada do aparecer) só se sustenta se fundada numa lógica (ou num saber absoluto do ser)" (lbid.).

Ricoeur afirma que seu interesse está nessas dificuldades, que são quase insuperáveis, pois ele acredita que elas são capazes de nos instruir sobre o problema que põe a filosofia contemporânea por um retorno a Hegel e os diferentes neo-hegelianismos atuais. Para Ricoeur, o que Hyppolite está a fazer nada mais é que preparar o terreno através de uma elucidação da linguagem humana, que se destina a mostrar que a mais elevada forma da experiência humana é a revelação da identidade entre o ser e o saber. Observemos o que diz Hyppolite (1987, p.11):

Fica claro, então, que a mais alta forma da experiência humana (não há nada que esteja fora da experiência humana) é a revelação da identidade do ser e do saber, é a visão da estrutura desta consciência de si universal, dentro da qual o ser se diz, se expressa, indicando tanto a coisa da que se 
fala, como o eu que fala. Seguir assim esse movimento da categoria, diversificando-se em categorias, em momentos ou nos particulares de uma cadeia dialética, é fazer uma lógica da filosofia e é este, certamente, o sentido da organização hegeliana ${ }^{10}$.

De acordo com Ricoeur, Hyppolite não tem dificuldade em mostrar que a renúncia ao discurso, e a inserção no sentimento, no silêncio, na solidão, no imediato é, por sua vez, renunciar à humanidade. Para Hyppolite, a humanidade é diálogo. Mas Ricoeur (L2, 1996, p.137) indaga: "Mas é esse o problema? A alternativa é entre o não-saber e o saber absoluto?". Para o autor não estamos nunca diante desse tipo de alternativa, uma vez que a nossa vida se passa muito mais em discursos imperfeitos e aproximativos. A questão, na verdade, para Ricoeur é a seguinte: "saber se todos os nossos discursos, que são de um modo ou de outro, discursos de... e discursos sobre... (digamos, de alguém sobre algo), pressupõem um discurso que seja o próprio discurso do ser, sem objeto longínquo, sem falante singular" (Ibid.).

A proposta de Hyppolite, a sua apologética, se limitou a buscar nos discursos relativos do pensamento a "indicação" de um pensamento absoluto que "se preocupe" sempre a si mesmo. Logo, o que faz Hyppolite é um movimento de ir e vir entre as sugestões da experiência e o abrupto postulado do saber absoluto.

Ricoeur salienta que não vê como problemático o não-discurso, mas o que é problemático é justamente aquilo que superamos a partir do momento que falamos: 0 afetivo, o qualitativo e o violento. $O$ filósofo crê que se falamos é porque já superamos; mas se considerarmos que o superado é também conservado, nenhum sentido torna-se transparente, a nossa percepção permanece

\footnotetext{
10 "Se hace claro, entonces, que la más alta forma de la experiencia humana (no hay nada que esté fuera de la experiencia humana) es la revelación de la identidad del ser y del saber, es la penetración en la estructura de esta conciencia de sí universal, en el seno de la cual el ser se dice, se expresa, enunciando tanto la cosa de la que se habla, como el yo que habla. Seguir así el movimiento de la categoría, diversificándose en categorías, en momentos o nudos particulares de una cadena dialéctica, es hacer una lógica de la filosofía y es éste, ciertamente, el sentido de la empresa hegeliana".
} 
perspectivista, "contestada pelo outro, ou mesmo pelo que eu vejo, do qual eu sei apenas que vê o que eu não vejo" (RICOEUR. L2, 1996, p.138).

Portanto, o sensível provoca a inexatidão de todos os discursos. E, quando eu digo que o homem só é homem na linguagem e na comunicação - lembrando que tal linguagem e tal comunicação requerem um discurso absoluto - acabo por abolir a inexatidão de todos os diálogos. É como abolir o singular no universal. Ainda há na questão da linguagem, o problema da não-linguagem, ou seja toda essa parte que não é discurso. E a própria palavra, como nos lembra Ricoeur (1996), quando busca igualar o sensível (a voz) ao sentido (o lógico). Ricoeur (L2, 1996, p.139) revela: "o movimento do sensível ao signo e ao símbolo, tal como a fenomenologia o desvela, parece-me testemunhar mais contra Hegel do que a seu favor".

Há uma necessidade de que o sensível se transcenda completamente, mas para Ricoeur o sensível não se transcende completamente, mas "quase", e esse "quase" é fenomenologia, se fosse "completamente", seria lógica. Portanto, o que é possível afirmar, segundo Ricoeur, é que "nunca se chega a ela [a lógica] pela fenomenologia, mas que sempre se parte dela, mesmo quando parece que se chega a ela" (Ibid.). E, por isso, Hyppolite afirma: "A lógica explica, pois, a fenomenologia" e, acrescenta: "o saber absoluto é, portanto, um resultado que se pressupõe a si mesmo na natureza e no espírito finito"11. Logo, parece inevitável dizer que "não haveria experiência possível sem a pressuposição do saber absoluto, mas o caminho da experiência indica o saber absoluto"12.

Na segunda etapa do texto, Ricoeur assume a sua dificuldade de tornar-se hegeliano e numa tentativa de encontrar um motivo para tal dificuldade menciona que, talvez ela se dê, pelo fato dele não ter entrado no tema central da lógica. $E$, então, ele nos diz:

\footnotetext{
11 "La Lógica explica pues la Fenomenología. [...] Un resultado que se presupone a sí mismo en lo que es; de la naturaleza y del espíritu".

${ }^{12}$ Cfr. HYPPOLITE, 1987, p.48; p.91: "No habría experiencia posible sin la presuposición del saber absoluto, sino que el camino de la experiencia indica hacia el saber absoluto".
} 
O absoluto é reflexão; o discurso do ser exibe um Si, um poder infinito de reflexão no movimento pelo qual uma categoria (isto é, uma determinação finita do ser) se nega, se faz outra, se aliena. A tenaz convicção que a primeira parte do livro de Hyppolite mal consegue fixar, segundo a qual a reflexão sempre segue 0 ser, não se deve à incompreensão do nãohegeliano dessa tese central da Lógica: que o ser se torna sua própria reflexão infinita? A partir daí, com efeito, uma apologética hegeliana não é mais uma apologética como as outras, pois seu próprio movimento faz parte da reflexividade do absoluto; a dialética não se desenrola mais acima de sua cabeça como um milagre da palavra; ela está implicada na aventura lógica. (RICOEUR, 1996, p.140).

Portanto, não é possível compreender tais expressões se não se refizer o trabalho pormenorizado da lógica, o movimento da primeira tríade (ser-nada-devir) se explicita no movimento pelo qual a lógica do ser, quando tomada em bloco, se inverte na lógica da essência e, portanto, também nas tríades imanentes a essa lógica. Acontece que os grandes círculos e os pequenos círculos se expressam mutuamente, por isso as equivalências acabam por se justificarem entre: refletir-se, negar-se, aparecer; mas somente consegue compreender essas relações quem percorreu todo o caminho, fez todo o trabalho do sistema hegeliano, passando inclusive pela sua lógica (RICOEUR. L2, 1996, p.140). E, é justamente esse 0 ponto nefrálgico do sistema hegeliano.

Sobre isso, nos diz Hyppolite (1987, p.76): "o absoluto é a aparição (isto é a reflexão) da tese na antítese e da antítese na tese, e a imediatidade, a igualdade a si mesma dessa reflexão infinita" ${ }^{13}$. E, acrescenta ainda que:

É o fato de aparecer - a noção ontológica que corresponde à consciência que define o momento da essência. Todo aparecer remete de um termo a

\footnotetext{
13 "Lo Absoluto es la aparición (es decir la reflexión) de la tesis en la antítesis y de la antítesis en la tesis, y la inmediación, la igualdad consigo misma de esta reflexión infinita".
} 
outro, ele é reflexão, mas a reflexão não é apenas subjetiva, ela pertence ao em si, ao ser que é sujeito ${ }^{14}$.

Por fim, após essa reflexão chegamos juntamente com Ricoeur ao momento de pôr fim à discrepância entre 0 nosso pensamento e 0 absoluto. Temos aqui a reflexão, a mesma que Kant e Fichte fizeram o princípio último da filosofia. A reflexão e o Si igualados ao próprio ser, enquanto esse ser é dialético (RICOEUR, 1996, p.141).

O que pretende o hegelianismo, segundo Ricoeur, é terminar com o mistério do ser, ou seja, o ser não é mais um segredo e, isso, somente é possível de desvendar com a reflexão, é ela que nos permite dizer que o imediato se reflete e se desvela, como o si, como faz Hyppolite: "O único segredo é que não há segredo. 0 imediato se reflete e se desvela como 0 si" ${ }^{15}$.

Para Ricoeur (L2, 1996, p.141) a reflexão de que fala a filosofia hegeliana, evocada por Hyppolite e da qual se falou acima, deixa fora de si mesma reflexões, ou seja, os níveis de reflexão imperfeita nos quais a subjetividade que se apreende não se esgota na própria constituição do absoluto.

Ricoeur diz que se sente surpreendido, que o recurso à reflexão, em Lógica e Existência, ao invés de extinguir a questão da discrepância entre 0 ser e 0 pensamento, acabe por recolocá-lo de outra maneira. Agora, é a própria reflexão que se duplica. Observemos o que diz Hyppolite: "o si da reflexão não é mais o si humano tomado em consideração numa antropologia ou numa fenomenologia", e acrescenta: "o si deve se descentrar do pura e simplesmente humano para se tornar 0 si do ser" 16 .

\footnotetext{
${ }^{14}$ Cfr. HYPPOLITE, 1987, p.79: "Y este hecho de aparecer — la noción ontológica que corresponde a la consciencia define el momento de la esencia. Todo aparecer remite de um término a otro, es reflexión, pero la reflexión no es solamente subjetiva, pertenece al en-sí, al ser que es sujeto".

${ }_{15}$ Cfr. 1987, p.111: "Pero el único secreto es que no hay secreto. Lo inmediato se refleja y se devela como el sí".

${ }^{16}$ Cfr. HYPPOLITE, 1987, p.91: "El sí humano que se toma en consideración en una antropología o en una fenomenologia" e "El sí debe descentrarse de lo pura y únicamente humano para llegar a ser el sí del Ser".
} 
A indagação de Ricoeur não poderia ser outra: 0 que se ganhou ao afirmar que 0 ser é reflexão, se 0 si continua sendo 0 outro, se 0 homem permanece 0 outro?

Embora não da mesma forma e não com relação ao ser como nas filosofias não dialéticas como de Descartes e de Kant, mas ainda com relação ao Si do ser. Logo, de que adiantou todo o processo, todo o trabalho para igualarmos a reflexão e o si ao próprio ser, se este si ainda não é o nosso? (RICOEUR. L2, 1996, p.141).

Para Ricoeur, isso justifica o fato de a segunda e terceira parte do livro de Hyppolite reconduzirem o leitor ao mesmo esforço e à mesma dificuldade pela qual passou na primeira parte. Se na primeira parte era necessário demonstrar que as linguagens (perceptiva, técnica, matemática, poética) "indicam" o Logos, embora 0 Logos "se pressuponha" sempre a si mesmo nessas linguagens relativas; na segunda e terceira parte se faz necessário demonstrar que a "reflexão especulativa", que a "negação dialética", que a "proposição especulativa" se pressupõem a si mesmas nos modos empíricos da reflexão, da negação, da proposição (op. cit. p.142).

A negação permanece um movimento subjetivo, exterior ao campo da afirmação; como ocorre com Kant, por exemplo, ao "refletir" sobre as estruturas formais, vazias de conteúdo, que tornam possível uma experiência objetiva; mas sua reflexão retém uma subjetividade que regra, mas não gera esses conteúdos e que, pelo menos nesse sentido, permanece consciência infeliz; pois a consciência permanece sempre separada do absoluto. Ricoeur (1996) afirma que Kant teve prudência transcendental, que para ele é reconhecimento do limite, contrário às pretensões do entendimento.

Dentre todos os exemplos e apontamentos que Paul Ricoeur apresenta acerca de Hegel, mas principalmente da filosofia hegeliana apresentada pelos hegelianos, como Hyppolite, por exemplo, parece-nos que a negação hegeliana toma destaque. Principalmente a negação hegeliana apresentada por Hyppolite em seu livro Lógica e Existência.

O que se destaca em tal apresentação é justamente o fato que é reforçado por Hyppolite, no sentido de não se exorcizar a ideia de nada à moda bergsoniana como falso problema, uma vez que "a negação ressurge como um princípio de 
distinção entre as coisas, os organismos, os indivíduos e, também como inversão do élan criador, origem de toda a materialidade, todo entendimento e sua geometria" (RICOEUR. L2, 1996, p.142). Embora não se possa utilizá-la como contradição, como sinal de erro, assim como a lógica do pensamento empírico, ou como aporia da razão nos moldes de Kant na Crítica da Razão Pura (KrV), nos paralogismos e nas antinomias (op.cit.).

Neste sentido, as grandes filosofias acabam por fracassar ao tentarem dar um estatuto à negação, o que aos olhos de Ricoeur é algo favorável a Hegel. Ainda assim, ele salienta que nenhuma apologética, nem mesmo a de Hyppolite, 0 convence de que Hegel tenha resolvido melhor o problema do que Platão, por exemplo, para quem a negação era meramente distinção, alteridade, mesmo que para Hyppolite "a dialética hegeliana impulsionará essa alteridade ao contrário até a contradição"17.

Ricoeur (1996) questiona até que ponto é legítima a afirmação de Hyppolite, em sua apologética, que destaca a dialética de Platão como imóvel e que apenas uma dialética em movimento esclarece como a diversidade se transforma em diversidade em oposição e da oposição em contradição. Para Ricoeur, nessa passagem brusca, está todo o Hegel.

Acerca dessa contradição de si no pensamento hegeliano, Hyppolite diz:

É por essa contradição de si a si que o pensamento ontológico se desenvolve; ele capta as determinações do Absoluto, ou as categorias, como momentos de negativos, como diferenças do Absoluto, mas o Absoluto só é ele mesmo nessa negatividade ou na negação da negação.

Ele se põe a si mesmo, e é essa posição de si na oposição que constitui a Mediação infinita ${ }^{18}$.

\footnotetext{
17 "La dialéctica hegeliana llevará, al contrario, esta alteridad hasta la contradicción" (1987, p.140, tradução nossa).

18 "Es por esta contradicción de sí así que el pensamiento ontológico se desarrolla; éste capta las determinaciones de lo Absoluto o categorías, como momentos negativos, como diferencias de lo Absoluto, pero lo Absoluto sólo es él mismo en esta negatividad o en la negación de la negación. Él se pone a sí mismo, y esta posición de sí en la oposición constituye la Mediación infinita" (1987, p.151, tradução nossa).
} 
De acordo com Ricoeur (1996, p.143), esse é "o enorme postulado que nenhuma fenomenologia 'indica', se ele não se 'pressupõe' a si mesmo". Embora tenhamos acompanhado todas essas abordagens pela negação, 0 enigma continua sem solução: se o absoluto é sujeito e idêntico a si mesmo ou conceito, mas ainda é o si do ser que se põe nessas determinações e se identifica a si na sua negação.

Não podemos esquecer que Hyppolite insiste constantemente que o Si (do ser) não é o homem. Ao tomar tal constatação como pressuposta, não colocaria todo o hegelianismo, inclusive o de Hyppolite em contradição? Parece-nos que 0 próprio Hyppolite recusa isso. $\mathrm{E}$, ciente disso, como Hyppolite (1987) tenta resolver essa cisão entre o Si (do ser) e o homem? Colocando a reflexão como alienação do Logos numa Natureza. É através da reflexão que o Absoluto gera e compreende seu Outro.

Assim, a partir do que propõe o hegelianismo, principalmente Hyppolite, numa tentativa de evitar o divórcio entre o Si e o homem, Ricoeur salienta que podemos concluir, ao menos, três coisas: i) o ser é o seu próprio Logos; ii) esse Logos é a própria reflexão e, por fim, iii) a reflexão é a sua própria alienação. Portanto, para Ricoeur não é possível aceitar essa cisão entre o Si e o homem, que nos propõe a ontologia de Hegel, mas menos ainda a saída que é dada por Hyppolite, de uma ontologia partida. E, Ricoeur crítica ainda essa noção de saber (logos) que tem por base um conhecimento baseado na finitude do homem. Esses são os pressupostos para uma primeira recusa à tentação hegeliana e ao hegelianismo.

Uma vez anunciada, a recusa Ricoeuriana, a primeira tentação, que consiste em retornar a Hegel (principalmente aquele da Lógica) numa tentativa de promoção da ontologia, em detrimento da antropologia. Se ao retornar a Hegel, para tratar a questão ontológica, a questão do ser, caímos, novamente, na dicotomia entre o $\mathrm{Si}$ e homem. E, se optarmos por seguir o hegelianismo, principalmente Hyppolite, - Ricoeur (L2, 1996) afirma que Hyppolite conseguiu ser mais hegeliano do que o próprio Hegel -, ao colocar que é através da reflexão que 0 absoluto gera e compreende 0 outro. Vejamos na próxima seção a segunda tentação hegeliana no que tange a razão prática. 


\section{2- Segunda tentação: Hegel e a razão prática}

Uma vez reconhecida a potência do pensamento de Hegel, é preciso resistir a tentação hegeliana, a tentação de recair na mediação absoluta, na totalização. Não apenas com relação à questão si, mas também no campo da razão prática. $E$ é justamente em seu livro Du texte à l'action (1986), que Paul Ricoeur escreve mais uma seção dedicada a Hegel e a segunda tentação hegeliana. Com o cuidado com relação à sua crítica a Kant, Ricoeur parece preocupado em esclarecer que não pretende sair de Kant para cair em Hegel novamente.

\subsection{1- A razão prática}

Paul Ricoeur se dedica à construção de um conceito de razão prática, que deve satisfazer ao menos a duas exigências que ele mesmo impõe: i) que mereça chamar-se razão; ii) que conserve características irredutíveis à racionalidade científico-técnica.

O filósofo reconhece que com essa intenção acaba se aproximando de Habermas e Perelman, mas faz questão de deixar claro os pontos em que se distancia deles. Distancia-se de Habermas por não proceder por disjunção, por tipologia, mas por composição de conceitos. E, mesmo concordando com a distinção entre racional e razoável, difere de Perelman quando tenta se apoiar na tradição filosófica (RICOEUR. TA, 1989, p.237).

Ricoeur desenvolve o capítulo intitulado $A$ razão prática, começando com um conceito elementar de razão prática e conclui com um conceito altamente complexo. No primeiro momento ele trata da teoria contemporânea da ação, no qual busca as noções de "razão de agir" e de "raciocínio prático", passando de uma semântica a uma sintaxe da ação, e de uma sociologia compreensiva com as noções de "regras de ação" e de "conduta submetida a regras", chegando então nas duas problemáticas clássicas de "ação sensata" de Kant e Hegel (op. cit.).

$\mathrm{Na}$ teoria da ação, o conceito de razão prática identifica-se com as condições de inteligibilidade da ação sensata, ou seja, aquela de que um agente pode dar conta a outro ou a si mesmo - de modo que aquele que recebe o relato 0 aceita como inteligível. Mesmo que em alguns casos a ação seja "irracional", ela permanece sensata enquanto encontra condições de aceitabilidade estabelecidas 
numa comunidade de linguagem e valor. Tais condições de aceitabilidade são as que as respostas satisfazem às perguntas, até esgotá-las por completo, ou seja, quando as respostas satisfazem a curiosidade e os questionamentos do interlocutor.

Ricoeur começa com o pressuposto de que a ação não é muda e nem incomunicável, pois podemos dizer o que fazemos e porque o fazemos. E não é incomunicável, pois na interação com o outro, podemos comunicar o sentido que atribuímos à nossa ação e assim ela não permanece mais restrita, mas torna-se pública. "É publicamente que nos explicamos, nos justificamos, nos desculpamos" (RICOEUR. TA, 1989, p.239).

Para Ricoeur, a teoria da ação apenas explicita as condições de inteligibilidade que pertencem à semântica espontânea da ação. Mas ele está interessado nesse nível na noção de razão de agir. $E$ esta razão de agir se encontra implicada nas respostas de um agente que se reconhece capaz de dar respostas às questões que mencionamos anteriormente. Para ele há quatro traços principais que caracterizam a noção de razão de agir, a saber: i) o conceito se estende tão longe quanto o campo de motivação. De acordo com Ricoeur "a partir do momento em que a ação é percebida pelo agente como não imposta, um motivo é uma razão de agir" (TA, 1989, p.239). O filósofo acrescenta que mesmo um desejo "irracional" figura como caráter de desejabilidade, uma vez que devo sempre poder dizer em que medida é que eu desejo alguma coisa, e lembra que para Ascombe isso ocorre da mesma maneira.

Quando se submete as características de desejabilidade ao exame, quando o agente precisa explicar seus motivos, razões para determinada ação, seja a outro ou a si próprio -, é possível que tais características sejam explicitadas em termos de motivos que representam uma generalidade de determinada espécie e não retira a possibilidade de serem considerados "irracionais" também. Tal generalidade consiste em compreender os motivos (a desejabilidade) como pertencente a uma classe que pode ser identificada, nomeada, definida recorrendo a todos os recursos da cultura, desde o drama, o romance até os clássicos das paixões (RICOEUR. TA, 1989, p.240). Portanto, uma razão de agir permite explicar 
ou interpretar tal ação como exemplo de uma classe de disposições que apresentam um caráter de generalidade.

Contudo, o conceito de disposição quando implicado à noção de classe de motivos, nos conduz a uma espécie de explicação casual. Ora, ao explicarmos a ação ou interpretá-la a partir da sua disposição, nos conduz a explicá-la pela sua causalidade teleológica, a mesma que para Charles Taylor, é uma explicação em que a própria configuração global dos acontecimentos é um fator da sua própria produção. Ao dizer que determinado acontecimento ocorre porque é intencionalmente visado é dizer que as condições que o produziram são aquelas que, justamente por pertencerem ao nosso repertório do saber-fazer, são chamadas, requeridas e eleitas para produzirem o fim visado. E, neste sentido, para elucidar o tema, Ricoeur cita Charles Taylor: "A condição e aparecimento do acontecimento é que se realize um estado de coisas tal que possa trazer o fim em questão, ou tal que este acontecimento seja requerido para trazer este fim" (RICOEUR. TA, 1989, p.240).

Até aqui, no que tange a razão de agir, Ricoeur está muito mais próximo da Ética a Nicômaco de Aristóteles (Livro III), do que da Crítica da Razão Prática (KpV) de Kant. A análise de Ricoeur, assim como a de Aristóteles, não estabelece nenhuma ruptura entre desejo e razão, mas extrai do próprio desejo quando ele acresce à esfera da linguagem, as próprias condições de exercício da razão deliberante. Para Aristóteles, a afinidade entre desejo e deliberação se dava pela atribuição da ordem total da preferência deliberada a esta parte da alma irracional - alogos - que participa do logos, para distinguir a alma propriamente racional, mas também da alma irracional inacessível ao logos. Para Ricoeur, a noção aristotélica do desejo deliberado encontra seu equivalente moderno nos três traços que para o filósofo caracterizam a noção de agir, a saber: i) caráter de desejabilidade; ii) descrição do motivo como estilo interpretativo; e iii) estrutura teleológica de toda explicação em termos de disposição (RICOEUR. TA, 1989, p.241).

Segundo Ricoeur (1989), esses três traços são a base para que ele possa introduzir o quarto traço característico da noção de agir, este de caráter menos semântico e mais sintático. E é esse o traço que nos permite passar da noção de 
razão de agir para a de raciocínio prático. Este traço da noção de agir e 0 raciocínio prático nos aproximam do conceito mais rico de razão prática que nos traz o filósofo ao final do seu ensaio, um conceito que possui outros componentes que já não dizem mais respeito à teoria da ação.

Para introduzir o conceito de raciocínio prático, Ricoeur (op. cit.) enfatiza um aspecto da noção de razão de agir que, de acordo com ele, ainda não foi observado. Ocorre que a noção de razão de agir, conforme a concebe a teoria da ação, identifica-se com a categoria dos motivos de caráter, ao mesmo tempo, retrospectivo e interpretativo. Para ele, há razões de agir que mais se relacionam com a intenção com que fazemos algumas coisas do que com 0 caráter retrospectivamente intencional de uma ação feita que queremos explicar, justificar ou desculpar.

Logo, trata-se do próprio da intenção tomada no sentido de intenção com que... ou seja, significa instaurar entre duas ou mais ações um encadeamento de caráter sintático que se exprime por expressões do tipo: "fazer isto de tal modo que isso", ou mesmo por inversão, "para obter isso, fazer isto". Tal conexão entre duas proposições práticas se presta a encadeamentos de extensão variável. E é aqui que intervém o raciocínio prático, herdeiro do silogismo prático de Aristóteles.

Segundo Ricoeur, a sintaxe do raciocínio prático que está mais de acordo com os traços característicos da semântica da ação - tratados anteriormente -, é que se apoia na noção de razão de agir no sentido de intenção com que se faz alguma coisa. Para o filósofo a chave do raciocínio prático está numa ordem das razões de agir. Ou seja, a função do raciocínio prático é pôr em ordem as "longas cadeias de razões" suscitadas pela intenção terminal. Neste sentido, o raciocínio prático parte de uma razão de agir que é tida por última, ou seja, aquela que esgotou a série das questões, a série de "porquês", ou seja, parte de um caráter de desejabilidade (incluindo também o desejo de cumprir o seu dever) e, portanto, é esse caráter de desejabilidade que acaba por ordenar regressivamente a série de meios encarados para satisfazê-lo.

Ricoeur evoca Aristóteles: "só se delibera a partir dos meios" (TA, 1989, p.242). 0 que essa ordenação "orquestrada" pelo raciocínio prático requer é a distância entre o caráter de desejabilidade e a ação singular. Assim, com a 
distância posta intencionalmente, o raciocínio prático consistirá em ordenar a cadeia dos meios numa estratégia.

\subsection{2- A "regra de ação"}

Para Ricoeur, mesmo que a noção de razão de agir seja completada pela noção de raciocínio prático, está longe de cobrir todo o campo de significações implicadas pelo termo de razão prática (RICOEUR. TA, 1989, p.243). E, neste sentido Ricoeur introduz um aspecto decisivo que ainda não apareceu, a saber: 0 de ação regrada ou normatizada. A partir dessas considerações da ação regrada ou normatizada saímos do plano da teoria da ação que se confina, - por sua escolha metódica -, ao plano da ação individual que se desenvolve na vida quotidiana. Ainda que os motivos alegados estejam abertos à compreensão pública, ainda são motivos de um agente individual.

De acordo com a sociologia compreensiva (de essência weberiana) faltam várias componentes essenciais à noção de ação sensata. Por exemplo, a orientação para outrem e, nesse sentido, não basta que uma ação possa ser interpretada por um agente em termos de motivo cujo sentido é comunicado a outrem, é necessário que a conduta de cada agente leve em consideração a conduta do outro, seja com a intenção de se opor a ela, ou mesmo para entrar em composição com ela. É somente nesse sentido que se pode falar em ação social, quando se tem em consideração a conduta do outro, seja por ser contrário a ela, ou mesmo por concordar e querer compor com ela.

Ainda assim, é necessário acrescentar à noção de ação social a noção de relação social num curso em que o indivíduo não apenas considere a reação do outro, mas motive a sua ação por símbolos e valores, e uma vez que estes não expressam mais apenas as características privadas de desejabilidade tornadas públicas, mas regras, também públicas. $\mathrm{E}$ isto vale tanto para a ação, quanto para a linguagem.

Quando falamos estamos a significar o que dizemos, estamos fazendo uso de palavras e frases segundo a codificação atribuída pela comunidade linguística. Assim, quando transposta para a teoria da ação, a noção de código implicará que a ação sensata seja, de uma forma ou de outra, governada por regras. Logo, 
poderíamos dizer que toda ação que seja comunicada, tornada pública, é sem dúvida, governada por regras, uma vez que ao tentar significá-la através dos símbolos e códigos da linguagem, estamos obedecendo a regras. E, nesse sentido tomemos o exemplo dado por Ricoeur:

\begin{abstract}
O mesmo segmento de ação - levantar o braço - pode significar: peço a palavra, ou voto por, ou sou voluntário para tal tarefa. O sentido depende do sistema de convenções que atribui um sentido a cada gesto numa situação, ela mesma, delimitada por este sistema de convenções, por exemplo, uma reunião contraditória, uma assembleia deliberativa ou uma campanha de recrutamento (TA, 1989, p.244).
\end{abstract}

Para Ricoeur, pode-se, nesse caso, falar de mediação simbólica, como fez Clifford Geertz ${ }^{19}$, para realçar o caráter imediatamente público, não apenas da expressão dos desejos individuais, mas também da codificação da ação social na qual toma lugar a ação individual. Para Ricoeur, estes símbolos são entidades culturais e não apenas psicológicas (RICOEUR. TA, 1989, p.244). Estes símbolos estão imersos em sistemas articulados e estruturados, de forma que, mesmo que tomados de forma isolada, se intersignificam - sejam eles sinais de circulação, de regras de delicadeza ou de sistemas institucionais mais complexos e mais estáveis. É o que Geertz chama de "sistemas de símbolos em interação".

Essa noção de norma ou regra introduzida por Ricoeur não possui caráter de constrangimento, ou seja, de repressão, coerção, que alguns a atribuem. Para aquele que observa e está de fora, estes sistemas simbólicos fornecem um contexto de descrição para ações particulares. Portanto, é nos termos de, em função de... tal regra simbólica que se pode interpretar tal comportamento como (significando isto ou aquilo). Contudo, devemos tomar a palavra "interpretação" no sentido de Peirce: antes de serem para interpretar, os símbolos são interpretantes de conduta. Logo, nesse sentido, a ideia de regra ou de norma não implica nenhum constrangimento ou repressão (op. cit.).

\footnotetext{
${ }^{19}$ Ricœur cita Clifford Geertz ao falar sobre mediação simbólica referenciando a sua obra intitulada: The Interpretation of Cultures (1973), (RICOEUR. TA, 1989, p.244).
} 
Agora, se tomarmos na perspectiva dos agentes, o caso é ligeiramente diferente. Mas antes de causar constrangimento, as normas ordenam a ação, no sentido de que a configuram, Ihe dão forma e sentido. Logo, assim como os códigos genéticos, os códigos simbólicos são programas de comportamento, que dão significação e direção à vida. Assim como os códigos genéticos, os códigos simbólicos conferem certa legibilidade, que pode, eventualmente, dar lugar a uma determinada escrita, a uma etnografia em que a textura da ação é transposta para o texto cultural.

Embora não queira se estender na análise da ação mediatizada por símbolos, Ricoeur realça a contribuição dessa ação mediatizada por símbolos, para a sua investigação sobre o conceito de razão prática. Essa ação mediatizada por símbolos confirma a análise anterior acerca da noção da razão de agir e, ainda, Ihe fornece um equivalente sociológico. E, mais ainda, abre novas perspectivas ao introduzir a noção de norma e de regra.

Desta forma, o raciocínio prático que ficara confinado, a luz de Aristóteles, ao campo da deliberação sobre os meios, extrapola em direção aos fins. Já não estamos mais falando de pôr em ordem uma cadeia de meios numa estratégia, mas de argumentar sobre as próprias premissas maiores do silogismo prático (conservando o vocabulário de Aristóteles, mesmo com seu caráter criticável do ponto de vista lógico). Tal argumentação abrirá caminho às ideologias e utopias, das quais Ricoeur falará ao final do ensaio (op. cit.).

A diferença entre a deliberação sobre os fins e a deliberação sobre os meios pode ser explicada facilmente, de acordo com Ricoeur: uma reflexão sobre os fins em relação à ação apresenta uma distância de caráter novo, não é mais a distância entre um caráter de desejabilidade e tal ação a realizar, distância que 0 raciocínio prático é capaz de preencher: essa distância dos fins à ação é uma distância reflexiva, que é capaz de abrir um espaço para que se confrontem pretensões normativas opostas entre as quais a razão prática arbitra e termina 0 debate por decisões assimiláveis a sentenças do direito.

A distância reflexiva dá espaço para o surgimento da ideologia e da utopia, pois é nessa distância entre os fins e a ação que se origina o desvio da "representação" relativamente às mediações simbólicas imanentes à ação. Ricoeur 
(TA, 1989, p.245) admite que no plano individual um agente pode distanciar-se em relação às suas razões de agir e coordená-las numa ordem simbólica representada para si mesmo, independente da ação. Contudo, é no plano coletivo que este desvio da representação é mais manifesto. Tais representações são, nesse plano, essencialmente, sistemas de justificação e de legitimação, quer da ordem estabelecida quer de uma ordem suscetível de substituí-la.

Podemos chamar tais sistemas de legitimação de ideologias, mas desde que não se identifique, de forma apressada, ideologia e mistificação e de reconhecer às ideologias ${ }^{20}$ uma função mais primitiva e mais fundamental que qualquer distorção que consista em fornecer uma espécie de metalinguagem para as mediações simbólicas imanentes à ação coletiva (RICOEUR. TA, 1989, p.246).

Contudo, não trataremos ainda a distinção que Ricoeur faz entre ideologia como representação e ideologia como distorção sistemática e de mistificação. Fazse necessário antes falar da sua aproximação da situação do conceito de razão prática; e também da sua relação com Aristóteles e o conceito de práxis.

Em um primeiro momento a análise de Ricoeur acerca da noção de razão de agir, somente se aproxima da noção de preferência raciocinada, de proairèsis, que é apenas a noção psicológica de algo muito mais rico e inclusivo, que é a sabedoria prática. É notável que, de acordo com Ricoeur, a sabedoria prática acrescenta à noção psicológica outras componentes e, em princípio, uma componente axiológica (RICOEUR. TA, 1989, p.246).

Para Ricoeur, Aristóteles acaba por fazer uma definição, quando define as virtudes éticas, a fim de distingui-las das virtudes intelectuais ou especulativas, como se lê:

A virtude é um estado habitual que dirige a decisão (hexis proairétikè) que consiste numa medianidade - [ou um justo meio] - relativo a nós, cuja

\footnotetext{
${ }^{20}$ Cabe esclarecer que as ideologias são compreendidas por Ricœur, - ao menos nesse momento -, como representações tais que aumentam e reforçam as mediações simbólicas, ao torná-las, por exemplo, narrativas, crônicas, por meio das quais a comunidade "repete", de algum modo, a sua própria origem, a comemora e a celebra (RICOEUR, 1989, p.246). Ao final do estudo em questão, que estamos a analisar, Ricœur irá traçar as diferenças entre ideologia, no sentido de representação integradora e ideologia no sentido de distorção sistemática e de mistificação.
} 
norma é a regra moral, quer dizer, exatamente aquela que o sábio lhe daria. (Eth. Nic., II, G, 1107ª). (ARISTÓTELES apud RICOEUR. TA, 1989, p. 246).

Tal definição tem como mérito, de acordo com Ricoeur, coordenar uma componente psicológica (a preferência raciocinada); uma componente lógica (a argumentação que arbitra entre duas reivindicações percebidas uma como defeito, a outra como excesso, para chegar àquilo a que Aristóteles chama uma mediania); uma componente axiológica (a norma ou regra moral); a justeza pessoal do phronimos - para Ricoeur, o gosto ou relance ético que personaliza a norma (RICOEUR. TA, loc. cit.). Logo, o raciocínio prático, para o filósofo, caracteriza-se como o segmento discursivo da phronèsis.

Para Ricoeur, parece estar claro que "a phronèsis associa um cálculo verdadeiro e um desejo justo sob uma norma - um logos - que, por sua vez, não funciona sem a iniciativa e o discernimento pessoal" (op. cit.). E, assim, tudo isso tomado em conjunto forma a razão prática. Diante disto, Ricoeur afirma categoricamente que é impossível eliminar o momento kantiano desta problemática, contudo não significa que devemos substancializar tal problemática. Passamos agora à análise de Ricoeur acerca do momento kantiano da razão prática.

\subsection{3- Se a razão, enquanto tal, pode ser prática}

Uma vez assumido que é inevitável, ao se tratar da razão prática, passar por Kant, é preciso ressaltar que desta tomada de posição por Ricoeur, resultam, ao menos, duas considerações: primeiramente, que o conceito de liberdade é kantiano e não grego; e em segundo lugar, a emergência desse conceito de liberdade está, pela primeira vez com Kant, ligada a uma situação aporética da filosofia especulativa.

Neste momento, é possível perceber uma aproximação de Ricoeur em relação a Hegel, uma vez que, este afirma que foi Kant e não Aristóteles quem formulou a questão da liberdade no centro da problemática prática. Segundo Ricoeur, Hegel teria formulado de uma forma excelente as razões pelas quais 0 conceito de liberdade, no sentido de autonomia pessoal, não poderia ter sido concebido por nenhum filósofo grego; e, nesse sentido, obviamente, nem mesmo 
por Aristóteles (RICOEUR. TA, 1989, p.247). Para ele, é a partir de Kant que a liberdade prática é - independente do sentido - uma determinação da liberdade. $\mathrm{E}$, Ricoeur acresce que esta é uma ideia que ele próprio não abandonará até o final deste estudo (op. cit.).

O conceito de liberdade precisa, para Ricoeur (TA, 1989, p.247), ser reconhecido pela filosofia especulativa como "problemático, embora não impossível", para que seja formado o próprio conceito de razão prática. Logo, é necessário ultrapassar o destino da filosofia kantiana e ir em direção ao debate contemporâneo em torno da filosofia analítica.

Inicialmente é preciso começar através da escola da linguagem vulgar $e$ nela descobrir o que está implícito, assim como demonstrou Ricoeur, ao analisar os esboços iniciais da análise dos conceitos de razão de agir e de raciocínio prático. Feito isso, o passo seguinte é dado a partir de Kant, o que traz um avanço significativo à problemática. Há um distanciamento da linguagem vulgar e, segundo o filósofo, isso só é possível graças a Kant, que foi o responsável por trazer o conceito de liberdade ao plano especulativo, para que neste plano pudesse ser tematizado e problematizado. 0 conceito de liberdade só se torna um conceito filosófico após ser confrontado com a questão da ilusão transcendental. Portanto, Ricoeur (TA, 1989, p. 247) conclui: "problematizá-lo é mostrar que ele é problemático".

É nessa condição de problematizá-lo e de demonstrar que ele é problemático que a liberdade é uma ideia da razão e não do entendimento. $E$, portanto, toda a problemática anterior acaba por merecer ser posta sob o título de razão prática para Ricoeur. Temos assim uma virada na análise, quando admitimos essa ruptura epistemológica entre raciocínio prático e razão prática.

Diante disso, mais uma vez Ricoeur partirá do próprio filósofo e de sua obra para atacá-lo. Assim como fez com Hegel ao tratar da filosofia da história, faz com Kant ao tratar da razão prática. Para ele, é o próprio Kant que possibilita tais ataques ao conceber a razão prática como a determinação mútua da ideia de liberdade e da ideia de lei. Ora, pensar conjuntamente liberdade e lei, é o objeto da análise realizada na Crítica da Razão Prática (KrV) e, é nesse momento, que o conceito de razão prática toma sua tonalidade kantiana. A razão enquanto razão é 
prática, e assim ela mesma é capaz de determinar, sozinha, a priori a vontade, se a lei é uma lei da liberdade e não uma lei da natureza. Dito isso, passaremos a demonstrar quais são as razões apontadas por Ricoeur, pelas quais ele busca demonstrar que o conceito kantiano de razão prática deve ser ultrapassado, embora não possa ser contornado.

O que é posto em dúvida por Paul Ricoeur (TA, 1989, p.248) é "a necessidade de moralizar, de maneira total e tão unívoca, o conceito de razão prática"21. Para o filósofo, Kant "substancializou" ou "hipostasiou", para utilizar o termo utilizado pelo próprio Ricoeur, um único aspecto da nossa experiência prática, a saber: o facto da obrigação moral, que é concebido como constrangimento do imperativo. Para ele a ideia de uma conduta submetida a regras apresenta outras facetas além da do dever.

A partir disso, Ricoeur assume que a noção aristotélica de areté22 parece mais rica de significações, uma vez que ele considera restrita a ideia de submissão ao dever. Há alguma coisa que é preservada na noção de norma ou de regra, ou seja, a ideia de um "modelo-para-agir", ou seja, de um programa a ser seguido, de uma orientação que dá sentido. E, assim, a ideia de ética, para Ricoeur é mais complexa que a de moralidade, se compreender por moralidade a estrita conformidade ao dever sem ter em conta o desejo (RICOEUR. TA, 1989, p.248). E é isso que ele retoma mais adiante no texto, quando aborda Hegel.

Diante da necessidade ou não de moralizar de forma totalizante o conceito de razão prática, Ricoeur se questiona acerca da ideia kantiana de que a razão é por si mesma prática, ou seja, que é ela que comanda, enquanto razão, sem levar em conta o desejo, o que é para ele ainda mais questionável, uma vez que essa ideia acaba por comprometer a moral. Uma ideia de razão por si mesma prática coloca-nos numa série de dicotomias e dissociações, que põem fim à própria noção de ação; exatamente o que Hegel irá denunciar com sua crítica. Neste sentido, temos a moral comprometida diante das dicotomias entre forma contra

\footnotetext{
21 Grifo do autor.

22 Para Paul Ricœur a noção aristotélica de areté é melhor traduzida por excelência do que por virtude.
} 
conteúdo, lei prática contra máxima, dever contra desejo, imperativo contra felicidade.

Para Ricoeur (1989), a compreensão aristotélica da estrutura específica da ordem prática é melhor do que a kantiana, uma vez que Aristóteles cunhou a noção de desejo deliberativo e juntou desejo correto e pensamento justo no seu conceito de phronèsis. Além disso, Ricoeur direciona sua crítica para o projeto kantiano de construir a Crítica da Razão Prática sobre o modelo da Crítica da Razão Pura, sendo que para o filósofo francês isso é fortemente questionável, uma vez que temos ai uma separação metódica do a priori e do empírico. E acerca deste projeto e de uma analítica da razão prática, Ricoeur afirma:

A própria ideia de uma Analítica da razão prática que responderia, traço por traço, à da razão pura parece-me desconhecer a especificidade de domínio do agir humano que não suporta 0 desmantelamento a que condena 0 método transcendental, mas, muito pelo contrário, requer um agudo sentido das transições e das mediações (RICOEUR. TA, 1989, p.249).

Para Ricoeur, não é possível separar metodicamente, como fez Kant, o a priori e o empírico no que tange 0 agir. 0 agir humano requer um sentido, um motivo, e ao desconsiderar isso, Kant acaba por supervalorizar o a priori da regra da universalização. Além disso, para Ricoeur (op. cit.), a regra de universalização é "apenas um critério de controle que permitirá ao agente pôr à prova a sua boa fé, quando pretende 'ser objetivo'" nas máximas da sua ação.

Ricoeur menciona que Kant acaba por elevar à categoria de princípio supremo a regra de universalização e, assim, acaba seguindo o caminho que prevalece desde Fichte até Marx, a saber: que a ordem prática é passível de justificação de um saber e de uma cientificidade que podem ser comparados ao saber e à cientificidade que são requeridos na ordem teórica. $E$, como ficou demonstrado anteriormente pelo filósofo francês, há uma razão de agir, o sujeito possui motivos e muitas vezes estes são subjetivos, emocionais, psicológicos e não, simplesmente, objetivos. Embora Kant reduza esse saber a um enunciado do princípio supremo, ele acaba por abrir um espaço para as doutrinas da ciência (Wissenschaftslehre), que acabam por gerar a ideia de que existe uma ciência da práxis. 
Como alertou Aristóteles, não há uma ciência aplicada à prática, uma vez que, como declara o Estagirita, na ordem das coisas humanas, variáveis e submetidas à decisão, não é possível atingir o mesmo grau de precisão (acribia) como ocorre, por exemplo, nas ciências matemáticas, e que é necessário proporcionar sempre o grau de rigor da disciplina considerada nas instâncias do seu objeto (RICOEUR. TA, 1989, p.249).

Salientamos que Ricoeur considera que poucas ideias são tão saudáveis e libertadoras quanto à ideia de que há uma razão prática, mas não uma ciência prática. E nisso consiste um aspecto da crítica Ricoeuriana à analítica da razão prática kantiana. $O$ domínio do agir não é algo objetivo e metódico, o domínio do agir é, sob o ponto de vista ontológico, o das coisas mutáveis e, sob o ponto de vista epistemológico, o do verosímil, no sentido de plausível e de provável (RICOEUR. TA, 1989, p.250).

Obviamente que Ricoeur sabe que a responsabilidade não é de Kant e, tampouco, ele irá responsabilizá-lo por algo que não cometeu e nem sequer pretendeu, como o próprio Ricoeur afirma. Sua crítica é apenas uma, a saber: "ao construir o conceito de a priori prático sobre o modelo do a priori teórico, Kant transferiu a investigação sobre a razão prática para uma região do saber que não é a sua" (RICOEUR. TA, 1989, p.250).

Para Ricoeur, Kant deveria ter associado à noção de crítica da razão prática um sentido que não fosse derivado do da crítica da razão pura, mas com um sentido que apenas conviria à esfera do agir humano e, ao final do estudo, ele propõe a partir da crítica das ideologias, uma forma particular de reinvestir a noção de crítica no plano prático.

São esses os aspectos que Ricoeur elenca e os argumentos que ele apresenta para justificar que, àqueles que pretendem determinar o conceito de razão prática, passem por Kant incondicionalmente, mas não permaneçam em Kant. Para Ricoeur, é necessário que se siga adiante e, nesse sentido, ele chegará à temática que temos como central para este estudo, que é a tentação hegeliana. Ricoeur tem a preocupação de que ao tentar avançar em relação ao conceito de razão prática se acabe por cair na concepção hegeliana de ação. 


\subsection{4- A tentação hegeliana}

Diante da problemática tratada anteriormente, acerca do conceito de razão prática e os caminhos trilhados até aqui, Ricoeur faz, pela segunda vez, um alerta com relação à tentação hegeliana. 0 alerta é para que, ao criticar Kant, como ele fez, não se caia na tentação hegeliana. De acordo com ele, é necessário evitar essa tentação, por mais sedutora - intelectualmente - que ela seja. A concepção hegeliana de ação e a tentativa que ela representa devem ser evitadas. Contudo, Ricoeur assume que em muitos aspectos a sua crítica a Kant será hegeliana. Para ele, há razões muito precisas que ele pretende apresentar para que se evite cair na tentação hegeliana.

Ricoeur assume que, o que há de mais sedutor na concepção hegeliana da ação é a ideia de que é necessário procurar na Sittlichkeit - vida ética concreta as origens e os recursos da ação sensata. Ninguém começa a vida ética, não é nos dado o direito de debutar, de estrear na vida ética, todos nós a encontramos já-aí, num estado de costumes em que se sedimentaram as tradições fundadoras da sua comunidade.

Ricoeur enfatiza:

Se é verdade que a fundação original é já-aí, não pode ser representada senão sob forma mais ou menos mítica, ela continua, todavia, a agir, e permanece efetiva, através das sedimentações da tradição e graças às interpretações incessantemente novas que se dão destas tradições e da sua fundação original. Este trabalho comum do fundamento, das sedimentações e das interpretações, origina aquilo a que Hegel chama de Sittlichkeit, quer dizer, a rede das crenças axiológicas que regulam a divisão do permitido e do proibido numa dada comunidade (TA, 1989, p.250).

Embora Ricoeur tenha apresentado suas críticas, principalmente, com relação à associação feita por Kant de um sentido da razão pura à razão prática, este reconhece que a moralidade kantiana é fundamental, embora restrita, uma vez que ela constitui o momento de interiorização, de universalização, de formalização, com o qual Kant identifica a razão prática. Tal momento é importante, de acordo com Ricoeur, porque consiste na autonomia de um sujeito 
responsável, que é capaz de se reconhecer e se reconhece capaz de fazer aquilo que ele acha que é certo e ao mesmo tempo aquilo que tem dever de fazer, ou seja, que ele acha que deve fazer. Neste sentido, acerca da perspectiva hegeliana, diz Ricoeur:

Na perspectiva hegeliana, por sua vez, num desenvolvimento mais lógico do que cronológico das figuras do espírito, este momento de interiorização da vida ética concreta tornou-se necessário pela dialética inerente à própria Sittlichkeit. A bela cidade grega - se tem que ser considerada, pelo menos, como a melhor expressão da vida ética concreta antes do momento da moralidade abstrata - já não existe. As suas contradições internas levaram o espírito para além da sua bela harmonia. Para nós, modernos, a entrada na cultura é inseparável de uma libertação que acaba que nos torna estranhos às nossas próprias origens (TA, 1989, p.251).

O que ocorre é uma alienação da tradição. O nosso passado, as nossas tradições não nos pertencem mais e tampouco nos interessam, isso ocorre através do passado transmitido, o que acontece, de acordo com Ricoeur (1989), é uma distanciação do sentimento de pertença a essa herança cultural, a essas tradições, quaisquer que sejam.

Para Ricoeur, o momento da moralidade abstrata tornou-se insustentável pelas contradições que ele próprio origina. A crítica da "visão ética do mundo", na Fenomenologia do Espírito, e da moralidade subjetiva que faz eco nos Princípios da Filosofia do Direito, é conhecida por todos, e o próprio Ricoeur assumiu alguns dos seus argumentos, principalmente quando falou das dicotomias que o método transcendental kantiano origina no seio do agir humano e, também, quando sugere que a regra de universalização das máximas da vontade certifica a sua boa fé, e não o princípio supremo da razão prática (RICOEUR. TA, 1989, p.251).

Essa dupla crítica leva Ricoeur a ceder ao conceito hegeliano de vontade, tal como Hegel o concebe no início dos Princípios da Filosofia do Direito. Tal construção dialética contém em germe todos os desenvolvimentos anteriores que, quando tomados em conjunto, constituem-se numa contrapartida positiva da crítica da visão ética do mundo e da moralidade abstrata. É importante observar que Hegel, ao contrário de Kant, não separa de um lado a vontade determinada apenas 
pela razão e, de outro, a livre escolha que se coloca na bifurcação entre o dever e o desejo. Ao invés disso, Hegel propõe a constituição de uma dialética do querer, que segue a ordem das categorias da universalidade na particularidade e na singularidade.

Essa dialética do querer de Hegel consiste no querer que quer e não-quer, quer isto e não aquilo, ao mesmo tempo que quer algo, nega outra coisa. Assim, é uma dialética entre o querer e o não-querer. 0 querer particular acaba por negar 0 querer universal, mas que diferentemente de Kant, não se perde do universal, pois é capaz de retornar a ele e refletir, universalmente, acerca do próprio sentido deste particular. Logo, é a forma que a vontade tem de tornar-se particular permanecendo universal é, como diz Hegel, o que constitui a sua singularidade. Com a dialética hegeliana do querer, a singularidade deixa de ser algo inexprimível e incomunicável; por sua capacidade dialética acaba associando o sentido e a individualidade.

Acerca desta singularidade, Ricoeur diz:

Pensar a singularidade como individualidade sensata, parece-me uma das aquisições mais inegáveis que uma reconstrução do conceito de razão prática deve incorporar. Ele corresponde, na época moderna, àquilo que, para o pensamento antigo, foram a ideia complexa de "desejo deliberado" e a ideia englobante de phronèsis que constitui a "excelência" da decisão (TA, 1989, p.252).

Aqui nos parece claro que Ricoeur considera um passo importante esse dado por Hegel, de pensar a singularidade como uma individualidade sensata, não um solipsismo, mas uma singularidade que permanece universal; é um entrecruzamento entre o singular e o universal, não é um solipsismo, mas também não é uma universalização, uma generalização que acaba por anular a singularidade de cada um.

Até aqui falamos da dialética do querer, e segundo Ricoeur, foi dado o primeiro passo com Hegel, agora, se faz necessário dar um segundo.

$O$ segundo passo é aquele que o conceito de vontade anuncia e parece requerer, a saber: é necessário que nos ocupemos da filosofia política para a qual se orienta o retomar da Sittlichkeit para além da crítica da Moralität? E, é neste 
ponto em que a tentativa e a tentação hegeliana se sobrepõem. Anteriormente, nos foi possível demonstrar, a partir de Ricoeur, que a determinação mútua da liberdade e da lei tinha constituído, ao mesmo tempo, um dos pontos mais altos do conceito de razão prática e a fonte de todos os paradoxos que deviam pôr em crise toda a filosofia prática de Kant (RICOEUR. TA, 1989, p.250-252). A propósito, Ricoeur informa que, não por acaso, compara ambos os momentos de crise da investigação kantiana. Nos dois casos, há algo em comum, a saber: a tentativa de juntar liberdade e norma, seja no sentido que for.

Como sabemos, Kant tenta juntar a liberdade a um conceito de norma, que por sua vez, está reduzido ao esqueleto da regra de universalidade de uma máxima qualquer. $E$, mesmo assim, não consegue demonstrar que a razão é prática por si mesma, na exata medida em que o que a razão determina é uma vontade, que é abstrata e vazia. A razão não determina o agir concreto, como 0 requer, a ideia positiva de liberdade entendida como causa livre, ou seja, como origem de mudanças reais no mundo. 0 que ela determina é a vontade e não 0 agir concreto. $E$ é isso que Ricoeur demonstra em sua crítica a Kant (RICOEUR.TA, 1989, p.252).

Hegel, ao invés de buscar, na ideia de lei em geral, uma ideia vazia, a contrapartida de uma vontade que, de outro modo, permaneceria arbitrária, ele procura, nas sucessivas estruturas da ordem familiar, depois econômica e finalmente política, as mediações concretas que faltavam à ideia esvaziada de lei. Temos então uma nova Sittlichkeit, que não é anterior à moralidade abstrata, mas posterior a ela (em ordem conceitual). E, portanto, seria esta Sittlichkeit de nível institucional que constituiria o verdadeiro conceito de razão prática que tanto objetivou Paul Ricoeur em sua investigação (RICOEUR. TA, 1989, p.253).

Dito isso, é necessário mencionar que Ricoeur afirma estar mais propenso a seguir Hegel, ao menos até aí, quanto esta ética concreta restitui pós pensamento moderno; e neste sentido, também pós-kantiano, uma ideia muito forte em Aristóteles. Acerca disso, Ricoeur declara:

Nós somos tanto mais tentados a seguir Hegel até aí quanto esta ética concreta restitui, com os recursos do pensamento moderno, logo, póskantiano, uma ideia muito forte de Aristóteles, ou seja, que o "bem do 
homem" e a "tarefa" (ou a "função") do homem - estes tão preciosos conceitos do Livro I da Ética a Nicômaco - só se exercem completamente na comunidade dos cidadãos. O bem do homem e a função do homem só são preservados da dispersão em técnicas e artes particulares na medida em que a própria política é um saber arquitetônico, quer dizer, um saber que coordena o bem do indivíduo com o da comunidade e que integra as competências particulares numa sabedoria relativa ao todo da Cidade. É, assim, o caráter arquitetônico da política que preserva o caráter indiviso do bem do homem e da função do homem (RICOEUR. TA, 1989, p.253).

Para Ricoeur (TA, 1989, p.253-254), é preciso reconhecer essa visão que nasce na filosofia hegeliana do Estado. Temos o seu renascimento sob a forma moderna que supõe que o direito do indivíduo já está afirmado. Desta forma, a Lei sob a qual este direito pode ser reconhecido, só pode ser, a partir de agora, uma instituição política na qual o indivíduo encontra sentido e satisfação. E o núcleo de tal instituição é um Estado de direito, no qual a vontade de cada um se reconhece na vontade do todo. Trata-se da ação sensata na e pela vida política, que até então fora ultrapassada e sequer atingida. Contudo, tal ideia de Estado, proposta por Hegel, não só não progrediu em nada, como ainda recuou nos fatos.

Para Ricoeur, a ideia de uma mediação institucional da liberdade, como fora proposta por Hegel, regride aos pensamentos e aos desejos, uma vez que os nossos contemporâneos são, a cada dia, mais favoráveis e tentados por a uma liberdade selvagem, fora de instituições, uma vez que acabam concebendo que toda instituição é constrangedora e repressiva. Estes se esquecem do capítulo sobre o Terror, na Fenomenologia do Espírito, no qual Hegel equaciona liberdade e morte, quando nenhuma instituição mediatiza a liberdade. E se esse divórcio entre instituição e liberdade fosse duradouro, seria a maior negação da ideia da razão prática (RICOEUR. TA, 1989, p.254).

Contudo, cabe salientar que não é essa ideia de uma síntese da liberdade e da instituição que fará com que Ricoeur nos alerte para a necessidade de se evitar a tentação hegeliana. $\mathrm{O}$ que fará com que ele se afaste de Hegel é justamente 0 fato de que se pode duvidar fundamentalmente de que, para se elevar do indivíduo ao Estado, seja necessário distinguir ontologicamente entre espírito subjetivo e 
espírito objetivo, ou antes, entre consciência e espírito. Este é o ponto que Ricoeur considera de uma gravidade essencial. Sobre isso ele diz:

O termo espírito - Geist - marca uma descontinuidade radical com toda a consciência fenomenológica, quer dizer, com uma consciência incessantemente arrancada a si mesma pela falta e esperando o seu ser do reconhecimento de uma outra consciência. É por isso que, na Enciclopédia, a filosofia do espírito objetivo se desenvolve fora da Fenomenologia, na medida em que a fenomenologia permanece o reino da consciência intencional, privada do seu outro. Pode-se perguntar se esta hipóstase do espírito, assim elevado acima da consciência individual e mesmo acima da intersubjetividade, não é responsável por uma outra hispóstase, exatamente a do Estado. Não se podem suprimir do texto hegeliano, seja na Enciclopédia ou nos Princípios da Filosofia do Direito, as expressões pelas quais o Estado é designado como um deus entre nós (RICOEUR. TA, 1989, p.254. Grifos do autor).

Portanto, Ricoeur recusa essa hipóstase do Estado, que tem sua origem na ontologização do Geist. E, desta postura de recusa, decorrem algumas consequências que, para Ricoeur, devem também ser assumidas e que serão absolutamente decisivas para o destino da ideia de razão prática.

Primeiramente, Ricoeur salienta que ao recusarmos hipostasiar o espírito objetivo, é necessário explorar a fundo a alternativa de que deve ser sempre possível, de acordo com a Quinta Meditação Cartesiana de Husserl, ou seja, gerar todas as comunidades de mais alto nível, tais como o Estado, a partir da simples constituição de outrem numa relação intersubjetiva. E disso decorre que todas as outras constituições devem ser derivadas: primeiramente as do mundo físico em comum e, depois, as do mundo cultural comum, em que se comportarão, por sua vez, uns em relação aos outros como eus (des moi) de nível superior, confrontados com outros (des autrui) do mesmo nível.

É a sociologia compreensiva de Weber que contém, para o filósofo francês, o verdadeiro acionar do projeto da quinta Meditação cartesiana. Ou seja, é na sociologia compreensiva de Weber que temos a alternativa que poderia ser aceita, 
quando recusamos a primeira alternativa, aquela apresentada por Hegel, de hipostasiar o espírito objetivo. Sobre isso Ricoeur menciona:

Nem o seu conceito de ação social e nem o de uma ordem legítima, nem mesmo a sua tipologia dos sistemas de legitimação do poder põem em jogo outras entidades que não sejam os indivíduos comportando-se uns em relação aos outros e cada um regulando a compreensão da sua própria ação com base na compreensão dos outros. Este individualismo epistemológico parece-me mais capaz de resolver teoricamente a dialética da liberdade e da instituição, na medida em que as instituições aparecem como objetivações, ou seja, coisificações das relações intersubjetivas que nunca pressupõem, se ouso afirmá-lo, um suplemento do espírito (RICOEUR.TA, 1989, p.255).

Com isso Ricoeur quer demonstrar que, ao fazer tal escolha metodológica, respeitando o conceito de razão prática, temos algumas implicações que não podem ser desconsideradas. Ocorre que acabamos por jogar a razão prática ao nível dos processos de objetivação e de coisificação, e neste percurso, as mediações institucionais acabam por tornarem-se estranhas ao desejo de satisfação dos indivíduos. É importante mencionar as considerações de Ricoeur (op. cit.): "a razão prática, direi eu, é o conjunto das medidas tomadas pelos indivíduos e instituições para preservar ou restaurar a dialética recíproca da liberdade e das instituições, fora da qual não existe ação sensata".

Então, essa seria a primeira consequência que teríamos diante da nossa recusa à alternativa hegeliana: teremos de considerar outra alternativa, aquela que provém da Quinta Meditação Cartesiana de Husserl, que para Ricoeur, é acionada pelo conceito de ação social de Max Weber, mas que implicaria nesse processo objetivação e coisificação da razão prática, tornando as mediações institucionais estranhas ao desejo de satisfação dos indivíduos. Além desta implicação, que não pode ser desconsiderada, temos outra.

A segunda implicação da recusa do espírito objetivo de Hegel: a hipóstase do espírito objetivo não tem apenas uma significação ontológica, mas também uma significação epistemológica. Há nela uma pretensão de saber o espírito, de saber 0 Estado. Como coloca Ricoeur (Ibid.), "Não cessamos de ler: o Espírito sabe que 
ele próprio está no Estado e o indivíduo sabe que ele próprio está neste saber do Espírito"; e acrescenta ainda: "Disse várias vezes que nada, na minha opinião, é mais ruinoso teoricamente, nem mais perigoso praticamente, do que esta pretensão do saber, na ordem ética e política".

Para Ricoeur, tal pretensão de saber, teoricamente, nos leva novamente à mesma situação dicotômica que fora reprovada em Kant. Se em Kant tínhamos a dicotomia entre a intenção e o fazer, em Hegel, com a pretensão do saber, temos a dicotomia entre o Estado de intenção e o Estado real (como a crítica feita por Marx, dos Princípios da Filosofia do Direito, que para Ricoeur, é neste ponto forte). E, além disso, além de ser perigosa no âmbito teórico, a pretensão do saber é, também, ruinosa na prática.

Ricoeur afirma:

Ruinosa teoricamente, a pretensão ao saber é, além disso, perigosa na prática. Todos os fanatismos pós-hegelianos estão contidos in nuce na ideia de que o indivíduo se sabe no Estado, que ele próprio se sabe no Espírito objetivo. Porque, se um homem ou um grupo de homens, um partido, se arroga o monopólio do saber da prática, arrogar-se-á também o direito de fazer o bem dos homens, mesmo contra a sua vontade. É assim que um saber do Espírito objetivo gera a tirania (TA, 1989, p.256).

Se o monopólio da prática, essa pretensão do saber que é capaz de gerar 0 Estado, acaba por gerar a tirania, em contrapartida, seguindo o caminho inverso o de Husserl, de Weber e de Schutz -, concebemos que o Estado procede das próprias relações intersubjetivas, por um processo de objetivação e de alienação que fica para descrever. Mas, como já salientamos anteriormente, para Ricoeur (loc. cit.) "a razão prática não poderia erigir-se em teoria da práxis". E, assim, como Aristóteles, Ricoeur afirma que: "só há saber das coisas necessárias e imutáveis".

Para Ricoeur (TA, 1989, p.256), é necessário que não se eleve as pretensões da razão prática "para além da zona mediana, que se estende entre a ciência das coisas imutáveis e necessárias e as opiniões arbitrárias, tanto das coletividades como dos indivíduos" (Itálico do autor).

Portanto, essa é a segunda implicação apontada por Ricoeur: a da dicotomia entre intenção e fazer, entre o Estado em intenção e o Estado real, e se 
ao recusá-la podemos, ao seguir Husserl e, nesse sentido, a teoria da ação social de Max Weber, sermos conduzidos a uma pretensão do saber; que por sua vez, acaba por nos conduzir à tirania; e, por isso, é perigosa na prática. Cientes disso, podemos optar pelo caminho contrário, ao invés de seguirmos o caminho de Husserl, Weber e Schutz, acabamos por, novamente, propor uma razão prática que se erige da teoria da práxis, o que Ricoeur já alertou que não é possível. Por isso, precisamos manter a razão prática na zona mediana. De acordo com ele, é 0 reconhecimento deste estatuto mediano da razão prática é o que garante a sobriedade e a sua abertura à discussão e à crítica.

E, por fim, temos a terceira e última implicação que nos é dada por Ricoeur. Ao concebermos a razão prática como o conjunto das medidas tomadas para preservar ou instaurar a dialética da liberdade e das instituições, ela reencontra uma função crítica, quando perde a sua pretensão teorética enquanto saber.

Essa função crítica surge pelo reconhecimento do desvio entre a ideia de uma constituição política, na qual o indivíduo encontraria a sua satisfação, e a realidade empírica do Estado. Portanto, é deste desvio que precisamos dar conta ao propormos uma hipótese oposta à do Espírito objetivo de Hegel, ou seja, a hipótese de que o Estado e as outras entidades de alto nível da sociedade procedem da objetivação e da alienação das próprias relações intersubjetivas. $E$ sobre essa função crítica da razão prática que se faz necessária nesse momento, Ricoeur coloca:

Aqui, a função crítica da razão prática é desmascarar os mecanismos dissimulados de distorção pelos quais as legítimas objetivações do laço comunitário se tornam alienações intoleráveis. Chamo, aqui, legítimas objetivações ao conjunto das normas, das regras, das mediações simbólicas que fundamentam a identidade de uma comunidade humana. Chamo alienações às distorções sistemáticas que impedem o indivíduo de conciliar a autonomia da sua vontade com as exigências provenientes destas mediações simbólicas. É aqui, a meu ver, que aquilo a que se chamou "crítica das ideologias" se incorpora na razão prática como o seu momento crítico (TA, 1989, p.257). 
Como já mencionamos anteriormente, Ricoeur vê uma função positiva nas ideologias a propósito das mediações simbólicas da ação, uma vez que elas, enquanto sistemas de representações de segundo grau dessas mediações imanente à ação, têm a função positiva de integração do elo social. E, nesse sentido, elas dependem do que ele chama de legítimas objetivações do elo comunitário.

Agora, Ricoeur alerta também para o fato que há possibilidade deste estatuto representativo destas ideologias de integração obedecerem a mecanismos autônomos de distorção sistemática, em que um dos efeitos é o do Estado real estar tão afastado da ideia do Estado tal como foi produzida pela filosofia hegeliana (RICOEUR.TA, 1989, p.257). Por isso, a função de uma crítica das ideologias é: "preocupar-se com as raízes destas distorç̃es sistemáticas, ao nível das relações dissimuladas entre trabalho, poder e linguagem" (RICOEUR, loc. cit. Itálicos do autor).

Portanto, ao nos libertarmos das limitações que nos impõem os limites da simples compreensão do discurso pelo discurso, a crítica às ideologias é capaz de apreender uma outra função das ideologias, embora sempre misturada com a sua função de integração, ou seja, de legitimação de poder estabelecido ou de outros poderes prontos a substituírem-no com a mesma ambição e almejando o mesmo poder de dominação. Mas Ricoeur se dedicou a desenvolver neste estudo a relação entre ideologia e dominação, limitando-se às consequências que daí resultam para a razão prática.

Ricoeur diz:

A crítica das ideologias é, na minha opinião, um dos instrumentos de pensamento pelos quais a razão prática pode reconverter-se do saber em crítica. Então, é preciso falar menos de crítica da razão prática que de razão prática como crítica. É também preciso que esta crítica se não erija, por sua vez, em saber, segundo a ruinosa oposição entre ciência e ideologia. Não há, com efeito, lugar totalmente exterior às ideologias. É a partir do centro da ideologia que se ergue a crítica. A única coisa que pode elevar a crítica acima das opiniões arbitrárias sem a erigir, novamente, em saber, é, 
finalmente, a ideia moral de autonomia, funcionando, doravante, como motor utópico de toda a crítica das ideologias (TA, 1989, p.257-258).

O papel da utopia, para Ricoeur, é lembrar-nos que a razão prática não existe sem sabedoria prática, e esta, por sua vez, em situações de alienação, não existe sem que o sábio se tenha de tornar louco, já que os elos que regulam o elo social se tornaram loucos.

A utopia, conforme a concebe Paul Ricoeur - tendo em conta a sua dimensão positiva -, é inovadora quando tem por finalidade a criação de um sistema de representações que não está em conformidade com 0 sistema estabelecido. Neste sentido, a utopia é uma representação simbólica aplicável em outro tempo e outro lugar e não há um tempo e lugar presentes.

Logo, percebe-se o papel fundamental da utopia positiva, no sentido de que ela nos possibilita pensar e repensar o sistema estabelecido, é a representação que fizemos, que se refere a outro tempo e outro lugar, que pretendemos chegar, que almejamos alcançar. Este, talvez, seja o sistema ideal, as realidades que buscamos, onde pretendemos chegar; e se aplica tanto à sociedade quanto à educação que queremos.

\section{3- Renunciar a Hegel}

Em Temps et Récit é possível dizer que a chave do problema da refiguração reside no modo como a história e a ficção, tomadas conjuntamente, proporcionam às aporias do tempo, trazidas à tona pela fenomenologia, a réplica de uma poética narrativa.

O filósofo já havia em Temps et Récit I, no que tange aos problemas sob a égide da mímesis III, identificado o problema da refiguração como sendo o da referência cruzada entre história e ficção, e admitido que o tempo humano procede desse entrecruzamento no meio do agir e do sofrer. E, no terceiro volume da obra, não obstante isso, ele partirá de uma apreensão dicotômica dessas perspectivas.

Para o filósofo, numa tentativa de dar uma resposta às aporias da fenomenologia do tempo, a história acaba por elaborar um terceiro-tempo - 0 tempo propriamente histórico -, que é responsável por fazer a mediação entre 0 tempo vivido e o tempo cósmico. 
Numa tentativa de comprovar sua tese Ricoeur recorrerá aos procedimentos de conexão, que são tomados de empréstimo da própria prática histórica, e que asseguram a reinscrição do tempo vivido no tempo cósmico, a saber: calendário, sequência das gerações, arquivo, documento, vestígio. 0 filósofo admite que para a prática histórica esses procedimentos não são um problema, o problema consiste, justamente, em colocá-los em relação às aporias do tempo que fazem aparecer, para o pensamento da história, o caráter poético da história que nos levará aos embaraços da especulação.

Ricoeur afirma que reinscrever o tempo vivido no tempo cósmico do lado da história corresponde, do lado da ficção, a uma solução oposta das mesmas aporias da fenomenologia do tempo. 0 que, de certo modo, nos remete às variações imaginativas que a ficção opera nos principais temas dessa fenomenologia (RICOEUR. DA, 2012, p.170). Ele salienta ainda que, nos dois primeiros capítulos de Temps et Récit III, a relação entre história e ficção está marcada, quanto à sua respectiva capacidade de refiguração, pelo sinal de oposição. No entanto, é a fenomenologia do tempo a medida comum sem a qual a relação entre ficção e história ficaria absolutamente irresoluta.

Nos capítulos seguintes, o filósofo irá se direcionar à complementariedade entre história e ficção, tomando como problema central a relação da narrativa, tanto histórica quanto de ficção, com a realidade. É a partir da resolução deste problema que Ricoeur passará a utilizar o termo refiguração ao invés do termo referência. É precisamente a significação vinculada à palavra "realidade", aplicada ao passado, que Ricoeur espera renovar. E ele começa a fazê-lo, implicitamente, ao vincular o destino dessa expressão à invenção (no duplo sentido de criação e de descoberta) do terceiro-tempo histórico (RICOEUR. loc. cit.).

A segurança que a reinscrição do tempo vivido no tempo cósmico pode ter suscitado desaparece assim que topamos com o paradoxo relacionado com a ideia de um passado desaparecido que, no entanto, foi - "real". Esse conceito de passado "real" traz à tona os critérios ontológicos do acontecimento, que o autor havia deixado de lado cuidadosamente, em seu estudo da intencionalidade histórica, ao tratar a explicação histórica e a configuração por composição da intriga. 
Entre o passado "real" e a ficção "irreal" parece haver um abismo intransponível. Uma investigação mais fina não poderia, contudo, ficar nessa dicotomia elementar entre "real" e "irreal".

No capítulo III, Ricoeur demonstra ao preço de que dificuldades a ideia de passado "real" pode ser preservada e a que tratamento dialético tem de ser submetida. O mesmo se aplica, simetricamente, à "irrealidade" das entidades fictícias. Ao dizê-las "irreais", caracterizamos essas entidades em termos somente negativos. Mas as ficções possuem efeitos que exprimem sua função positiva de revelação e de transformação da vida e dos costumes. Por isso, a necessidade de se orientar por uma teoria dos efeitos.

O caminho, para Ricoeur, consiste em dois momentos. O primeiro momento percorrido ainda em TR II, com a introdução da noção de mundo do texto, no sentido de um mundo no qual poderíamos morar e desenvolver nossas potencialidades mais próprias. 0 mundo do texto só constitui por enquanto uma transcendência na imanência; a esse título, continua sendo algo do texto. 0 segundo momento consiste na mediação que a leitura opera entre o mundo fictício do texto e o mundo efetivo do leitor. Os efeitos da ficção, efeitos de revelação e de transformação, são essencialmente efeitos de leitura. De acordo com Ricoeur, é através da leitura que a literatura retorna à vida, ou seja, ao campo prático e pático da existência.

Logo, Ricoeur tenta, através de uma teoria da leitura, determinar a relação de representância no terreno da ficção. $O$ que lhe conduz para além da mera dicotomia, e até da convergência, entre a capacidade que a história tem e aquela que a ficção tem de refigurar o tempo, ou seja, ao cerne do problema que, em TR I, designou pelo termo referência cruzada entre história e ficção.

Ricoeur utiliza o conceito de refiguração cruzada ao referir-se aos efeitos conjuntos da história e da ficção no plano do agir e do padecer humanos. $\mathrm{Na}$ tentativa de atingir essa problemática, ele irá estender o espaço de leitura para toda a grafia: tanto para a historiografia como para a literatura. Dai resulta uma teoria geral dos efeitos que permite acompanhar, até seu estágio último de concretização, o trabalho de refiguração da práxis pela narrativa, tomada em toda a sua extensão. 
O problema, para Ricoeur, será o de mostrar como a refiguração do tempo pela história e pela ficção se concretiza por meio dos empréstimos que cada modo narrativo toma do outro. Os empréstimos consistirão no fato de que a intencionalidade histórica só se dá incorporando à sua perspectiva os recursos de ficcionalização que remetem ao imaginário narrativo, ao passo que a intencionalidade da narrativa de ficção só produz seus efeitos de detecção e de transformação do agir e do padecer assumindo simetricamente os recursos de historicização que lhe oferecem as tentativas de reconstrução do passado efetivo.

É das trocas íntimas entre historicização da narrativa de fiç̧ão e ficcionalização da narrativa histórica, nasce o chamado tempo humano, que nada mais é do que o tempo narrado.

Para Ricoeur, após todo esse percurso, resta ainda indagar sobre a natureza do processo de totalização que também permite designar por um singular coletivo o tempo assim refigurado pela narrativa. Este será o objeto dos dois últimos capítulos do Tempo narrado (Temps et Récit III).

Neste sentido, a questão é saber o que, pelo lado da narrativa, tanto de ficção como histórica, corresponde à pressuposição da unicidade do tempo. Assim, é dado um novo sentido à palavra "história" que será explicitado nesse estágio, sentido que excede à distinção entre histografia e ficção, e que admite como sinônimos melhores os termos consciência histórica e condição histórica.

A função narrativa, tomada em toda a sua amplitude, abarcando os desenvolvimentos da epopeia ao romance moderno bem como da lenda à historiografia, define-se em última instância por sua ambição de refigurar a condição histórica e elevá-la assim à categoria de consciência histórica. 0 novo sentido para o termo "história" é comprovado pela própria semântica da palavra, que designa, faz ao menos dois séculos, num grande número de línguas, tanto a totalidade do curso dos acontecimentos como a totalidade das narrativas que se referem a esse curso.

Esse duplo sentido da palavra "história" não resulta de modo algum de uma lamentável ambiguidade da linguagem, mas comprova uma outra pressuposição de nossa condição histórica, como a palavra "tempo", também o termo "história" designa um singular coletivo, que engloba ambos os processos de totalização em 
curso, tanto ao nível da história narrativa como ao da história efetiva (RICOEUR. TR3, 2012, p.174).

A correlação entre uma consciência histórica unitária e uma condição histórica igualmente indivisível torna-se assim a última questão de nossa pesquisa sobre a refiguração do tempo pela narrativa.

Aqui há a marca hegeliana na formulação do problema. É por isso que Ricoeur considerou impossivel subtrair-se da obrigação de examinar os motivos que tornam necessário passar por Hegel e aqueles, mais fortes, que, no entanto exigem renunciar a Hegel.

Ricoeur acredita ser necessário pensar a condição histórica como um processo de totalização, mas também necessário explicar que tipo de mediação imperfeita entre o futuro, o passado e o presente é suscetível de tomar o lugar da mediação total segundo Hegel. Essa questão remete a uma hermenêutica da consciência histórica, ou seja, a uma interpretação da relação que a narrativa histórica e a narrativa da ficção, tomadas conjuntamente mantêm com 0 pertencimento de cada um de nós à história efetiva, como agentes e pacientes.

Essa hermenêutica, diferentemente da fenomenologia e da experiência pessoal do tempo, tem a ambição de articular diretamente ao nível da história comum as três grandes ek-stases do tempo: o futuro sob o signo do horizonte de expectativa, o passado sob o signo da tradição, o presente sob o signo do intempestivo. Neste sentido, Ricoeur reconhece que poderá ser conservado o impulso dado por Hegel ao processo de totalização, sem ceder, contudo à tentação de uma totalidade acabada. Com esse jogo de remissão entre expectativa, tradição e surgimento intempestivo do presente, terminará o trabalho de refiguração do tempo pela narrativa.

Ceder ao processo de totalização, mas não à totalidade acabada!

Outra questão que Ricoeur visa esclarecer é se a correlação entre narrativa e tempo é igualmente adequada quando a narrativa é tomada em sua função de totalização em face da pressuposição da unidade do tempo e quando é considerada do ponto de vista do entrecruzamento das perspectivas referenciais da historiografia e da narrativa de ficção respectivamente. Essa questão remeterá 
a uma reflexão crítica sobre os limites com que topa nossa ambição de responder às aporias do tempo por uma poética da narrativa.

Dito isso, é possível vislumbrar o contexto e a discussão proposta por Paul Ricoeur no terceiro volume da sua obra Temps et Récit - Le temps raconté (1985). Neste terceiro volume, cujo teor foi abordado sinteticamente acima, Ricoeur expõe no sexto capítulo as motivações da sua terceira renúncia a Hegel.

Neste capítulo de Temps et Récit III (TR3), Ricoeur empenha-se em demonstrar, ainda na introdução do texto, o que lhe conduz a esse confronto com Hegel, a saber: o problema, como ele mesmo coloca, da pressuposição, reiterada por todas as grandes filosofias do tempo, da unicidade do tempo (RICOEUR, 2012, p.331). Para o filósofo, estas filosofias ao tratarem da questão do tempo parecem concordar com a representação do tempo como um singular coletivo. E, de acordo com Ricoeur, isto acaba por suscitar o problema que será objeto desta seção de TR III e do qual nos ocuparemos a partir de agora: do entrecruzamento das perspectivas referenciais da narrativa histórica e da narrativa da ficção, resulta uma consciência histórica unitária, capaz de se igualar a essa unicidade do tempo e fazer frutificar suas aporias.

A preocupação que conduzirá Ricoeur (TR3, 2012, p.330) ao confronto com Hegel pode ser expressa do seguinte modo: é possível uma consciência histórica unitária igualável à consciência unitária do tempo? Portanto, o filósofo transfere 0 problema da totalização da consciência do tempo para o âmbito da história. Propondo assim, o questionamento: é possível uma totalização da consciência histórica? De acordo com ele, é deste questionamento que nasce a tentação hegeliana e a necessidade de renunciar a Hegel, que falaremos mais adiante.

\subsection{1- A terceira tentação hegeliana}

Paul Ricoeur inicia a primeira seção do capítulo anunciando que, a história, tema da obra Lições sobre a filosofia da história ${ }^{23}$ e, portanto, da filosofia da

23 O texto Die vernunft in der Geschichte (1955) de Hegel teve publicação póstuma. Como Hegel não deixou um manuscrito finalizado, mas apenas anotações de aula, a edição alemã deve ser considerada uma versão "preparada", naturalmente, em sua essência baseada nas notas do próprio Hegel. Estas notas foram suplementadas e clarificadas por notas dos alunos, de que, felizmente, se 
história de Hegel já não é uma história de historiador, mas, sim, de filósofo. Ele diz: "Porque a ideia capaz de conferir à história uma unidade - a ideia de liberdade só é entendida por quem fez todo o percurso da filosofia do Espírito na Enciclopédia das ciências filosóficas" (RICOEUR. TR3, 2012, p.330). Logo, é necessário que se tenha compreendido todo o Sistema de Hegel, portanto, os filósofos. Nas palavras dele: "por quem pensou integralmente as condições que fazem com que a liberdade seja a um só tempo racional e real no processo de autorrealização do Espírito. Neste sentido, somente o filósofo pode escrever essa história" (RICOEUR, loc. cit.).

Assim, a história a que se refere Hegel só pode ser compreendida por filósofos, aqueles que compreendem, por sua vez, as condições que fazem com que a liberdade, seja racional e real, no processo de autorrealização do espírito. Não é mais uma história de historiadores, mas de filósofos. E, neste sentido, o estudo sobre os "tipos de histografia" que compreendem o "Primeiro esboço" contido na Introdução às Lições sobre a filosofia da história (1955) é na verdade um projeto didático que se destina a um público que não é familiarizado com as razões filosóficas que são estabelecidas pelo sistema hegeliano, que consiste em considerar a liberdade o motor de uma história capaz de ser concomitantemente racional e real.

Por isso, a necessidade de uma introdução, que Ricoeur chamará de exotérica, que acaba por conduzir, passo a passo, à ideia de uma história filosófica do mundo que só é recomendada, com bem frisa Ricoeur, por sua própria estrutura filosófica. O movimento que Hegel sugere - que vai da "História original" à "História reflexiva", e depois à "História filosófica" - repete o movimento da representação

encontrou dois conjuntos bastante extensos que foram utilizados pelo primeiro editor de sua obra, Eduard Gans. A edição de Gans apareceu em 1837. Uma edição revisada e ampliada, preparada por Karl, o filho de Hegel, foi publicada em 1840. Georg Lasson preparou uma terceira edição, ainda mais abrangente, publicada em 1917. Esta última edição difere no arranjo e no alcance da primeira e da segunda. Em geral se considera a segunda como a mais autorizada versão (HARTMAN, 2001, p.41). 
$(\text { Vorstellung })^{24}$. Eis aí o motivo pelo qual Ricoeur afirma que somente o filósofo pode escrever essa história.

Não há verdadeiramente uma introdução à "consideração pensante" da história, ao contrário, ela se estabelece sem transição nem intermediário, ou seja, sem mediação, apenas no ato de fé filosófico no sistema. 0 que se tem então é a ideia de razão, portanto, que esta governa o mundo e, nesse sentido, a história, por ser a história do mundo, se dá racionalmente. Logo, tem-se então o mesmo estatuto epistemológico que a "convicção" (Ueberzeugung), que se liga à certeza de si ${ }^{25}$, no momento em que o agente se tornou um, tanto com sua intenção quanto com o seu fazer.

Aqui nos parece importante ressaltar que como coloca Ricoeur:

Para o historiador, essa convicção é uma hipótese, uma "pressuposição", portanto uma ideia a priori imposta aos fatos. Para o filósofo especulativo, tem a autoridade da "autorepresentação" (da Selbstdarstellung) do sistema todo. É uma verdade: a verdade de que a Razão não é um ideal impotente, mas uma potência (TR3, 2012, p.331-332).

Neste sentido, as compreensões do filósofo e do historiador diferem quanto ao estatuto da razão. Para o filósofo, não há dúvidas quanto a essa convicção de que é a razão que governa o mundo e, portanto, a história do mundo não poderia ser outra, senão uma história racional, que se desenrolou racionalmente. Para 0 historiador, por sua vez, isso não passa de mera pressuposição, como ressalta Ricoeur, algo que, talvez, ele até possa tomar como verdadeiro, mas somente enquanto hipótese de trabalho, ou seja, como uma ideia a priori imposta aos fatos, nada além disto.

Por outro lado, para Ricoeur (TR3, 2012, p.332), esse credo filosófico é capaz de resumir não apenas a Fenomenologia do espírito, mas também a Enciclopédia, refutando assim a dicotomia entre um formalismo da ideia e um

\footnotetext{
${ }^{24}$ A representação (Vorstellung) é uma mediação entre a imediatidade da intuição e a efetividade do conceito. Há no interior da representação três modos que são distintos, mas se inter-relacionam: a) interiorização (ou rememoração, Erinnerung); b) imaginação; c) memória. (HEGEL, 1995, p.225-262). ${ }^{25}$ Conforme é possível evidenciar ao final do capítulo VI da Fenomenologia do espírito (1807).
} 
empirismo do fato. $O$ que é tomado como uma sentença verdadeira, a saber: "o que é, é racional - o que é racional, é" (RICOEUR, loc. cit.). E isso é comprovado por todo o sistema hegeliano. Logo, somente o filósofo que é conhecedor e compreende todo o projeto hegeliano seria capaz de aceitar tal argumento. Desta forma, "os argumentos que são capazes de revelar a inadequação do sistema são eles mesmos tomados de empréstimo da doutrina completa, que não tem precedente" (RICOEUR, loc. cit.).

Hegel não pôde, numa obra relativamente popular como Lições sobre a filosofia da história, retomar e explicar todo o seu sistema, ou mesmo reproduzir o aparelho da prova que a Enciclopédia das ciências filosóficas toma emprestado da lógica filosófica e, por isso, o que ele nos traz é uma explicação mais exotérica e construída em quatro momentos, a saber: objetivo, meios, material, efetividade. De acordo com Ricoeur, "essa progressão em quatro tempos tem ao menos a vantagem de lançar luz sobre o caráter dificultoso do equacionamento entre 0 racional e o real, que uma reflexão mais curta, restrita à relação entre meios e fim, pareceria poder estabelecer a um custo menor" (TR3, 2012, p.333).

Hegel coloca nesse primeiro tempo do processo de pensamento, ou seja, no que ele chama de objetivo, o postulado do fim último da história, que segundo ele, se confunde com o fim último do mundo, a saber: a autorrealização da liberdade, uma vez que a filosofia da história pressupõe o sistema todo. Esse ponto de partida distingue desde o início a história filosófica do mundo também conhecida como "consideração pensante da história". Por isso, Ricoeur (op. cit. p.333) salienta que, consequentemente, compor uma história filosófica do mundo será ler a história - principalmente a política - sob uma ideia (a de liberdade) que somente a filosofia legitima inteiramente. $E$, assim, a filosofia traz a si mesma na postulação da questão.

Para Hegel, não por acaso o processo se dá em quatro tempos, é necessário que o fim encontre o seu próprio "meio", não algo que lhe seja externo, mas interno. Pois é assim que será possível demonstrar que a Razão é capaz de mobilizar as paixões e as ideias, revelando assim a sua intencionalidade oculta. É ao satisfazer os seus fins particulares que esses eleitos do Espírito realizam os objetivos que os ultrapassam, portanto, é necessário o sacrifício das 
particularidades, estas consistem apenas no primeiro passo da Filosofia do Espírito, é necessário ir além no processo, encontrar seus meios e, por conseguinte, como ressalta Hegel na Introdução às Lições mesmo ao encontrar os meios ainda falta algo para que a efetividade do Espírito seja igual à sua finalidade última.

Ainda na Introdução de Lições o filósofo alemão irá salientar que se deve seguir um longo desenvolvimento dedicado ao "material" da livre Razão. 0 "material" é para Hegel o Estado, o "solo" no qual está enraizado todo o processo da efetuação da liberdade. E é "em torno deste polo que gravitam as potências que dão consistência ao espírito dos povos (religião, ciências e artes)" (RICOEUR. TR3, 2012, p.339). E, de acordo com Ricoeur, o que mais chama a atenção, chegando inclusive a causar espanto, é o tipo de corrida de perseguição que começa a partir da seção (das Material), e que parece sugerir que o projeto de efetuação (Verwicklichung) do Espírito nunca se encerra (RICOEUR, loc. cit.).

No quarto estágio do processo, temos a "efetividade" que é marcada pelo estabelecimento do Estado de direito com base na ideia de constituição e, ainda, na Introdução de Lições temos uma grande seção dedicada ao "curso (Verlauf) da história do mundo" e nele o princípio de desenvolvimento deve se articular numa sequência de "etapas", na qual nasce o próprio "curso" da história do mundo e será somente com esse curso que o conceito de história filosófica do mundo estará completo, ou melhor, com ele se poderá começar a trabalhar, uma vez que apenas o que resta é compor a história filosófica do Mundo Antigo, que nada mais é que 0 palco das nossas considerações, ou seja, a história do mundo.

Dito isso, parece-nos claro que, assim como ocorre com as filosofias do tempo, ao pensar uma consciência unitária do tempo, o leitor se sinta tentado a recorrer a uma consciência unitária da história e, assim, não resista à tentação hegeliana, e acabe sucumbindo a uma mediação totalizante, como propôs o filósofo alemão. Por isso, acreditou-se ser necessário, até agora, explicar ainda que brevemente, como Hegel apresenta de forma sintética e um tanto mais simples, as quatro etapas de seu sistema na Introdução de Lições. O que comprova, a nosso ver, uma das críticas feitas por Ricoeur à proposta de Hegel, que a história de que trata em sua obra, não é mais uma história de historiador, 
mas sim de filósofo, apenas o filósofo que tenha compreendido todo o sistema hegeliano, será capaz de compreender a história, que ele chama de "história do mundo", e não de "história universal", como bem frisa Ricoeur.

Feito isso, passa-se à apresentação dos motivos que, de acordo com Paul Ricoeur, acabam por inviabilizar a mediação total proposta por Hegel, no que tange à consciência histórica. É deste tema que nos ocuparemos a partir de agora.

\subsection{2- A impossível mediação total na História}

Para Paul Ricoeur, torna-se impossível uma crítica a Hegel que não seja pura e simplesmente a expressão da sua incredulidade diante da principal proposição hegeliana, no que tange a filosofia da história, a saber: "A única ideia que a filosofia traz é a simples ideia da Razão - a ideia de que a Razão governa 0 mundo e que, por conseguinte, a história universal também se desenrolou racionalmente" (RICOEUR. TR3, 2012, p.344).

Desta forma, Ricoeur (2012) reconhece que a filosofia da história hegeliana perde a sua credibilidade ao tentar se fundamentar na própria razão, sendo assim, o que o próprio filósofo chamará de um evento no campo das ideias. Não temos como ter certeza de que produzimos esse evento e nem tampouco se ele simplesmente aconteceu conosco. Acerca desse evento, o filósofo francês diz: "[...] sobre o qual não sabemos dizer se ele marca uma catástrofe que ainda nos fere ou uma libertação cuja glória não ousamos expressar" (RICOEUR. TR3, 2012, p.344).

Para Ricoeur, a saída do hegelianismo - seja pela via de Kierkegaard, de Feuerbach e de Marx, ou da escola histórica alemã - parece, como ele mesmo declara, a posteriori, uma espécie de origem. O filósofo francês diz:

Esse êxodo está tão intimamente implicado em nosso modo de questionar que não podemos legitimá-lo por alguma razão mais elevada do que aquela que dá o seu título à Razão na história, assim como não podemos pular nossa própria sombra. (RICOEUR, loc. cit.).

Parece-nos que é a própria Razão, tão evocada na filosofia da história de Hegel que acaba por refutá-lo por completo. Portanto, a principal conclusão 
Ricoeuriana consiste em dizer que a filosofia da história hegeliana resulta numa tautologia.

Para Ricoeur:

Uma crítica de Hegel tem de enfrentar a afirmação central de que o filósofo pode ter acesso não só a um presente que, resumindo o passado conhecido, contém em germe o futuro antecipado, mas a um eterno presente, que assegura a unidade profunda do passado ultrapassado e das manifestações da vida que já se anunciam através daquelas que compreendemos porque acabam de envelhecer (TR3, 2012, p.345-346).

Ora, parece-nos que a exemplo do que fizeram as filosofias do tempo, Hegel nos ofereceu uma consciência unitária do tempo, que resultou na refutação da sua própria filosofia da história.

O passado ultrapassado, retido no presente de cada época, e igualado ao eterno presente do Espírito, é essa a passagem que muitos sucessores de Hegel não conseguiram realizar. Por isso, Ricoeur pergunta: "O que é, com efeito, o Espírito que faz manterem-se coesos o espírito dos povos e o espírito do mundo? É o mesmo Espírito que, na filosofia da religião, sucessivamente exige e recusa as narrativas e os símbolos do pensamento figurativo?" (TR3, 2012, p.346).

Para Ricoeur (op. cit.), a proposta hegeliana não se sustenta porque não é possível igualar o presente eterno à capacidade que o presente atual tem de reter o passado conhecido e de antecipar o futuro desenhado nas tendências do passado. É a noção de história, ela própria abolida pela filosofia; quando o presente, igualado ao efetivo, abole sua diferença relativamente ao passado. Uma vez que a compreensão por si da consciência histórica, tal como nos apresenta Hegel, nasce precisamente do caráter incontornável dessa diferença.

Para Ricoeur, é o que está contido nessa asserção que se tornou inacreditável:

0 mundo atual, a forma atual do Espírito, sua consciência de si, compreende (begreift) em si tudo o que apareceu na história sob a forma das gradações anteriores. É certo que estas se desenvolveram sucessivamente e de maneira independente, sob formas sucessivas; mas o 
que o Espírito é, ele sempre foi em si e a diferença provém unicamente do desenvolvimento desse em si (HEGEL apud RICOEUR. TR3, 2012, p.348).

De acordo com Ricoeur, se a equação entre desenvolvimento e presente não se sustenta mais, acaba que todo o sistema desmorona. Por isso, ele indaga: "Como ainda poderíamos totalizar os espíritos dos povos em um único espírito de mundo?" (RICOEUR, loc. cit.). E, para ele foi a própria substância do que Hegel tentara alçar à categoria de conceito, ou seja, a diferença, que acabou por revoltarse contra o próprio desenvolvimento (Stufengang ${ }^{26}$ ).

Ricoeur anuncia a deterioração do que ele chamou de "conglomerado conceitual" reunido por Hegel sob o título de efetuação do Espírito. Pois, para 0 filósofo, o interesse dos indivíduos já não parece satisfeito e, também, deve-se considerar o fato de que a paixão dos grandes homens da história, ou seja, os nossos heróis e mártires, já não são mais capazes de carregar, por si só, o peso do Sentido. E, por isso, afirma:

[...] Concomitantemente, todos os componentes que se recobriram no conceito de astúcia da Razão - interesse particular, paixões dos grandes homens históricos, interesse superior do Estado, espírito dos povos e espírito do mundo - dissociam-se e parecem-nos hoje membra disjecta de uma impossivel totalização. A expressão "astúcia da razão" até deixa de nos intrigar. Repugna-nos, antes, como o faria a falha de um mágico sublime (RICOEUR, 2012, p.349).

Para Ricoeur, a efetuação da liberdade não pode ser considerada a intriga de todas as intrigas. Logo, "a saída do hegelianismo significa renunciar a decifrar a suprema intriga” (RICOEUR. TR3, 2012, p.350).

A compreensão da finitude do ato filosófico, que consiste a compreensão por si da consciência histórica, de acordo com Ricoeur, está em reconhecer que tal compreensão pode ser afetada desse modo por eventos sobre os quais não podemos dizer se os produzimos ou se simplesmente aconteceram conosco.

\footnotetext{
${ }^{26}$ Cfr. em RICOEUR. TR3, 2012, p.349. Os termos: Espírito em si, desenvolvimento e diferença juntos significam Stufengang der Entwicklung. Neste caso, Stufengang é tomado com desenvolvimento, processo gradual (RICOEUR. TR3, 2012, p.348-349).
} 
Portanto, isto acaba por demonstrar, como dito anteriormente, a finitude deste ato filosófico.

Assim, abandonado o hegelianismo, Ricoeur menciona que a consideração pensante da história, como tentou Hegel, era ela própria "um fenômeno hermenêutico, uma operação interpretante, submetida à mesma condição de finitude" (RICOEUR, TR3, 2012, p.350). Assim, Ricoeur admite que a tentativa de saída do hegelianismo, pela caracterização do hegelianismo, por um evento no campo das ideias, como mencionamos anteriormente e, portanto, dependente da condição finita de compreensão da consciência histórica por ela mesma, não pode ser considerada como um argumento contra Hegel. Ricoeur diz: "o que tal saída demonstra é que não pensamos mais conforme Hegel, mas depois de Hegel" (RICOEUR, Ibid.).

Por fim, Ricoeur assume que seu feito, até este momento, consiste apenas em caracterizar o hegelianismo como um evento no campo das ideias; que este evento depende da condição finita da compreensão da consciência histórica por ela mesma; e, que isso, não consiste num argumento contra Hegel. Apenas quer mostrar que ele já não pensa mais como Hegel, mas depois de Hegel, ou seja, a partir de Hegel. E a fim de esclarecer o que está em questão, Ricoeur evoca Gadamer em Verdade e método, quando este menciona inicia a segunda parte do seu livro com a seguinte declaração: "se reconhecermos para nós a tarefa de seguir Hegel e não Schleiermacher, a história da hermenêutica deverá receber uma nova inflexão". E, mais, para Gadamer (1999, p.273), só se pode recusar a Hegel mediante argumentos que produzem momentos reconhecidos e ultrapassados de sua empreitada especulativa, ou mais, que isso, contra as falsas interpretações e as refutações fracas, é preciso "preservar a verdade do pensamento hegeliano" (GADAMER apud RICOEUR, 2012, p.351).

Ricoeur reconhece que foi seduzido pela potência do pensamento de Hegel e que sente ter que abandoná-lo. E parece que após apresentar os motivos que 0 levam a esse abandono, busca em Gadamer uma justificativa semelhante para tal atitude: "O ponto de Arquimedes que permitiria tirar a filosofia hegeliana de seus gonzos jamais poderá ser encontrado na reflexão" (GADAMER apud RICOEUR, 2012, p.351). 
Após, Ricoeur informa à qual tipo de renúncia Gadamer está se referindo, a saber: "Sai do 'círculo mágico' por meio de uma confissão que tem a força de uma renúncia. Aquilo que renuncia é à própria ideia de uma 'mediação (Vermittlung) absoluta entre história e verdade"' (RICOEUR. TR3, 2012, p.351, itálicos do autor).

Esta é a posição de Ricoeur, que muito se aproxima da posição de Gadamer, uma crítica mais severa ao hegelianismo, por se caracterizar de um evento no campo das ideias e, diante de tais afirmações dos hegelianos, é necessário que se preserve a verdade do pensamento de Hegel, assim como sugere Gadamer. E esclarece que sua decisão de abandonar Hegel, não se trata de ir contra Hegel, mas de ir além, ou seja, a partir de todo pensamento de Hegel, de todo o seu sistema, é necessário ir além, renunciar a mediação absoluta, abandoná-la para ir além. 


\section{A MEDIAÇÃO IMPERFEITA}

Nos capítulos anteriores procuramos demonstrar a proximidade e ao mesmo tempo a renúncia de Paul Ricoeur com relação ao pensamento de Hegel. Não é possivel negar que Ricoeur sente-se seduzido pelo pensamento hegeliano e que ele se propõe a recusá-lo, de certa forma, mas sem negar que é preciso passar por ele (RICOEUR. TR3, 2012, p.351). Logo, recusa-se a ideia de uma mediação perfeita, totalizante, absoluta, mas não a noção de mediação.

Para Ricoeur, é necessário que se reconheça a importância do pensamento de Hegel. Ele não resiste em demonstrar que fora seduzido pelo pensamento do autor da Fenomenologia do Espírito, contudo, embora aponte os seus motivos para recusá-lo, salienta que a recusa se dá após conhecê-lo. Tratase de não cair na "tentação hegeliana" de aceitar a ideia de totalização, de um saber absoluto, contudo, recusá-lo não significa ignorá-lo, tampouco recusar sua dialética.

Ricoeur não aceita a proposta integral de Hegel, o seu Sistema, mas menos ainda as propostas dos hegelianos (na esteira de Hyppolite e outros), embora não rejeite a dialética hegeliana como fazem Deleuze e Derrida, e também, não esteja de acordo com a ideia de uma dialética negativa, como propõe Adorno. Ele não recusa a dialética e, desta forma, não é possível negar o uso frequente que ele faz do termo "dialética" ou "mediação" (SHEN, 2010, p.12).

Agora, se Paul Ricoeur não se recusa a utilizar o termo "dialética", e, também, não concorda com a proposta da dialética de Hegel, mas é de certa forma seu tributário, cabe a pergunta: a qual dialética ou mediação se refere Ricoeur? Essa é questão que tentaremos responder inicialmente e, após, procuraremos elucidar como e onde Ricoeur aplica a sua mediação. 
Não é possível pensar uma compreensão de si que não seja mediada através de sinais, símbolos e textos, uma vez que, como afirma Ricoeur (Cl, 1990, p.68): "o ser se diz de múltiplos modos". Passamos agora para a mediação imperfeita em Ricoeur.

\subsection{A mediação imperfeita}

Paul Ricoeur acredita que há, ao menos, uma diferença irredutível entre um projeto de filosofia chamado "filosofia da interpretação" e o hegelianismo, a saber: "a interpretação é sempre uma função da finitude"27; ao que acrescenta: "eu não posso me colocar como Hegel em um ponto onde eu veria o todo" ${ }^{28}$.

Por isso, faz-se importante reconhecer o trabalho de Hegel e considerar a proposta hegeliana de uma dialética para que possamos, em um segundo momento, abordar a dialética Ricoeuriana. A dialética proposta por Hegel se mostra mais clara na Enciclopédia das ciências filosóficas onde "a lógica", "a natureza" e "o espírito" são tratados respectivamente e mediatizados totalmente pelo saber absoluto. 0 saber absoluto se manifesta como a negação da negação, a contradição de si, que estimula um dinamismo temporal que se lê nas figuras do espírito.

Para Hyppolite, a dialética hegeliana, chamada pelo próprio Hegel de Aufhebung ${ }^{29}$, indica ao mesmo tempo 0 ato de suprimir, de conservar e de ultrapassar. Hyppolite foi o responsável pela tradução francesa da Fenomenologia do Espírito e afirma que a operação dialética designada pelo termo Aufhebun ou Aufheben é intraduzivel em francês. De acordo com ele, essa operação dialética consiste, para Hegel, no "trabalho do negativo" ${ }^{30}$.

\footnotetext{
27 "L'interprétation est toujours une function de la finitude" (RICOEUR, 2006, p.193).

${ }^{28}$ Cfr. RICOEUR, 2006, p.193: "Je ne peux pas me mettre comme Hegel en un point d'où je verrais le tout".

29 Para Hyppolite, os termos hegelianos "Aufheben, Aufhebung" são delicados em francês, ele chega a afirmar que são intraduziveis em francês, por isso, ele opta por utilizar supprimer, conserver e "dépasser" (ultrapassar) ao invés de "soulever" (aumentar).

30 Cfr. HYPPOLITE, 1940, p.19-20, nota 34: "Le travail du négatif".
} 
A dialética hegeliana, através dos seus sentidos ricos e ambíguos, propõe, senão um progresso, ao menos uma teleologia que sintetiza dois opostos. A noção de dialética manifesta uma oposição progressiva. Apesar de uma cisão diádica, há aí uma conexão muito dinâmica, e Hegel encadeia todas as esferas isoladas religando-as e dando-as numa perspectiva, o que, desde então, faz que a exigência hegeliana consista em redescobrir a reconciliação nos conflitos, mesmo onde um é contra o outro, como acontece, por exemplo, na dialética do senhor e do escravo (SHEN, 2010, p.130).

A proposta dialética de Hegel consiste numa reconciliação em três momentos, a saber: a lógica, a natureza e o espírito. E, desta dialética, Ricoeur conserva apenas a figura do espírito, mas no seu acontecer, ou seja, como realidade humana, como práxis, pois é na práxis que se podem observar as oposições produtivas. A realidade humana a que se refere Ricoeur parece corresponder ao "espírito", mas não no sentido hegeliano do termo espírito, uma vez que Hegel declara: "o Absoluto é o espírito" (HEGEL, 2005, p.437).

Portanto, uma das tentações a ser evitada é a do saber absoluto hegeliano, por isso, é necessário distinguir "a realidade humana" e "o espírito". Para Ricoeur, a realidade humana é o lugar privilegiado da dialética, mas isso não significa que ele aceite a definição hegeliana do do termo "espírito", pois, para ele, o espírito em Hegel, ao final do percurso, ainda possui vestígios do saber absoluto.

A mediação como concebida por Ricoeur não é totalizante como a hegeliana, mas aberta, imperfeita ou, como dirão alguns, fragmentária ${ }^{31}$. A dialética Ricoeuriana se inscreve na área do espírito em geral, mas recusa o saber absoluto. E neste sentido ele afirma:

A questão da prioridade se coloca quando a reivindicação pelo saber absoluto se torna apenas uma pretensão. Todas as questões sobre a dialética são precedentes deste colapso, da nossa incredulidade no que diz respeito à pretensão do saber absoluto. Todos aqueles que, por várias razões, se dizem dialéticos se afastam dessa incredulidade; isto porque

\footnotetext{
31 Acerca disso: "Quando a dialética não se exerce mais totalmente, ela torna-se fragmentária". "Quand la dialectique ne s'exerce plus totalement, ele devient fragmentaire" (SHEN, 2010, p.130, tradução nossa).
} 
eles não levam em suas mãos os pedaços quebrados do sistema em colapso. Minha própria investigação não é exceção à regra ${ }^{32}$.

Agora, mesmo rejeitando o saber absoluto hegeliano, Ricoeur afirma que não se deve rejeitar toda a dialética por conta do saber absoluto. Portanto, ele rejeita o saber absoluto, pois esta é uma tentação a ser evitada, mas não rejeita a dialética. Então, que dialética é essa defendida por Ricoeur?

De acordo com Shen, a prioridade negativa proposta por Hegel com Ricoeur dá lugar à alteridade. A dialética hegeliana é uma dialética do negativo e a dialética Ricoeuriana se inscreve no sentido da dialética da alteridade. E mais, é possível afirmar que a dialética de Ricoeur se situa entre Hegel e Kierkegaard, e entre Hegel e Kant (SHEN, 2010, p.131-132).

A dialética de Ricoeur se situa entre a dialética totalizante de Hegel e a dialética rompida de Kierkegaard, baseada na fé que recusa a mediação da razão na crença religiosa, o que Kierkegaard chamou de "paradoxo". E, além disso, a dialética de Ricoeur juntou a imaginação produtiva kantiana, mas alargando-a graças à exigência de efetivação hegeliana.

Acerca da dialética rompida de Kierkegaard, Ricoeur afirma:

Ele é didático porque não pode mais ser dialético. Ou, noutros termos, ele substitui uma dialética de três termos por uma dialética rompida, por uma dialética não resolvida de dois termos. Uma dialética sem mediação, tal é 0 paradoxo kierkegaardiano. Ou demasiadas possibilidades, ou muita atualidade; ou muita finitude, ou muita infinitude; ou se quer ser si mesmo, ou não se quer ser si mesmo. Mas ainda, como cada par de contrários não

\footnotetext{
${ }^{32}$ Cfr. RICOEUR, 1973, p.93, tradução nossa: "La question de priorité se pose dès que la prétention au savoir absolu s'avère n'être qu'une prétention. Toutes nos questions sur la dialectique procèdent de cet effondrement, de notre incrédulité à l'égard de la prétention au savoir absolu. Tous ceux qui, à titres divers, se disent dialecticiens partent de cette incrédulité ; c'est pourquoi ils ne tiennent dans leur main que les morceaux brisés du système effondré. Ma propre investigation n'échappe pas à la règle".
} 
oferece resolução, não é possível edificar o paradoxo seguinte que o precede; a cadeia de paradoxos é, ela mesma, uma cadeia rompida ${ }^{33}$.

Portanto, como é possível perceber, para Ricoeur, a "dialética rompida" de Kierkegaard está inscrita na recusa de toda a mediação possível. Essa dialética rompida se parece com uma antinomia, uma luta sem trégua, na qual não há trégua entre um e outro. Aqui se encontra a abordagem Ricoeuriana de uma mediação aberta, inacabada e imperfeita, que não permite uma oposição absoluta entre um e outro, e busca novamente a possibilidade de reconciliação por um esforço, no entanto, limitado.

Nesse momento, Ricoeur recorre à imaginação produtiva. Ao responder à crítica de Derrida sobre a idealização hegeliana, Ricoeur mantém o termo hegeliano Aufhebung, mas no seu sentido limitado da antropologia, por sua correspondência com o esquematismo kantiano (SHEN, 2010, p.133).

Em seu trabalho acerca da metáfora e a narrativa, Ricoeur afirma no prólogo de Temps et Récit, tomo I, que: "em ambos os casos [a metáfora e a narrativa], a inovação semântica pode ser relacionada com a imaginação produtiva e, mais precisamente, com o esquematismo que é sua matriz significante" ${ }^{4}$. E acrescenta: "esta consiste em esquematizar a operação sintética, em figurar a assimilação predicativa da qual resulta a inovação semântica"35.

Essa dupla influência (de Hegel e de Kant) se reflete no pensamento de Ricoeur. A influência do primeiro, no que tange à vontade de efetuação, de

${ }^{33}$ Cfr. em RICOEUR. L2, 1996, p.22-23: "Il est didactique parce qu'il n'est plus dialectique. Ou en d'autres termes, il remplace une dialectique à trois termes par une dialectique brisée, par une dialectique non résolue à deux termes. Une dialectique sans médiation, tel est le paradoxe kierkegaardien. Ou bien trop de possibilité, ou bien trop d'actualité ; ou bien trop de finitude, ou bien trop d'infinitude ; ou bien on veut être soi-même, ou bien on ne veut pas être soi-même. Bien plus, comme chaque paire de contraires n'offre pas de résolution, il n'est pas possible d'édifier le paradoxe suivant sur celui qui le précède ; la chaîne des paradoxes est ellemême une chaîne rompue".

34 Cfr. em RICOEUR. TR1, 1983, p.11: Na edição francesa de TR1: "Dans l'un et dans l'autre cas, l'innovation sémantique peut être rapportée à l'imagination productrice et plus précisément, au schématisme qui en est la matrice significante".

35 Cfr. em RICOEUR. TR1, 1983, p.12. Itálicos do autor: "Consiste à schématiser l'opération synthétique, à figurer l'assimilation prédicative d'où resulte l'innovation sémantique". 
realização concreta; e do segundo, na aplicação da imaginação na esfera da ação. Acerca dessa influência e da aplicação da imaginação no campo da ação, realizada por Ricoeur, Shen afirma:

Além disso, como a imaginação produtiva - a "síntese do heterogêneo" não significa mais uma síntese total, nem em Kant, nem em Ricoeur, a expressão "dialética fragmentária", parece-nos, que bem sublinha o limite desta produção sintética. Ricoeur expande então Kant por Hegel que ele limita; e ele limita Hegel por Kant que ele expande ${ }^{36}$.

A dialética aberta, imperfeita, proposta por Ricoeur é uma dialética baseada no paradoxo, mas que busca a reconciliação e a alteridade. É uma dialética que busca a alteridade e a conciliação com o outro, mas sem uma síntese dialética total, sem a totalização.

A lugar da dialética para Ricoeur, como ele demonstra em seu artigo Le lieu de la dialectique, pode ser demonstrado a partir da abordagem de quatro pontos, como faz Shen (2010, p.134-147): primeiramente, a dialética não é tudo, mas somente um procedimento de reflexão para a superação da abstração e para chegar ao concreto, ou seja, ao completo, ao todo. Ao menos essa era a pretensão de Hegel, mas que é limitada de acordo com Ricoeur, porque ela não se encaixa na reflexão humana. Acerca disso, podemos verificar em De l'interprétation (1965): "a dialética não é tudo; é apenas um procedimento da reflexão para ultrapassar sua abstração, para se tornar concreta, isto é, completa" ${ }^{37}$. Dito isso, é necessário explicar o que significa "reflexão", que é um dos núcleos da hermenêutica de Ricoeur. É o que abordaremos na próxima seção.

\footnotetext{
${ }^{36}$ Cfr. 2010, p.133, tradução nossa: "De plus, comme l'imagination productrice - la "synthèse de l'hétérogène" - ne signifie pas une synthèse totale, ni chez Kant, ni chez Ricoeur, l'expression "dialectique fragmentaire", nous semble-t-il, souligne bien la limite de cette production synthétique. Ricoeur élargit donc Kant par Hegel qu'il limite; et il limite Hegel par Kant qu'il élargit".

${ }^{37}$ Cfr. em RICOEUR. DI, 1977, p. 282: "La dialectique n'est pas tout ; c'est seulement une procédure de la réflexion pour surmonter son abstraction, pour se rendre concrète, c'est-à-dire complète".
} 


\section{2- A consciência como tarefa}

Como dito anteriormente, assim como Fichte e Nabert, Ricoeur não aceita a imediatidade do Cogito cartesiano, pois, para ele, mesmo que não se possa negar a evidência do Cogito, ainda assim, não se atingiu a verdade. Como ele aponta em Le conflit des interprétations (1969): "a posição do si é uma verdade que se põe a si mesma" ${ }^{38}$. Contudo, esta afirmação não pode ser deduzida e nem verificada, essa é uma verdade que se põe à reflexão. Não podemos fugir dessa verdade a que chegou Descartes com o Cogito, eu sou, eu penso e existo enquanto penso.

Assim, considerar o Si como existente e pensante, não é suficiente para caracterizar a reflexão, pois isso não nos permite a compreensão dos motivos pelos quais necessitamos de um trabalho de decifração, uma exegese e uma ciência da exegese ou hermenêutica; e menos ainda, se essa decifração for uma psicanálise (como propõe Freud) ou uma fenomenologia do Sagrado. A ideia de uma "psicologia racional", que Kant já havia refutado, também não é suficiente pelo mesmo motivo. E, para Ricoeur (Ibidem.): "este ponto não pode ser entendido enquanto a reflexão aparecer como um retorno à pretensa evidência da consciência imediata"39. A imediatidade da consciência, do Cogito, não é capaz de esclarecer o que é a reflexão.

É importante destacar que a reflexão, no sentido Ricoeuriano do termo, se distingue também daquele sentido dado por Hyppolite - "o absoluto é reflexão" -, que nós já tratamos anteriormente ${ }^{40}$. Ricoeur insiste na importância do caráter humano da reflexão. Para ele, a reflexão não é intuição, ela é um esforço para reaprender o ego do ego Cogito, em seus objetos, em suas obras e, por fim, em seus atos. Aqui cabe a pergunta: ora, não é esse o propósito da obra de Ricoeur? Por enquanto, deixaremos em suspenso essa questão e retornaremos a ela mais adiante.

Acerca disso, Ricoeur (Cl, 1990, p.321) menciona:

\footnotetext{
${ }^{38}$ Cfr. em RICOEUR. Cl, 1990, p.321: "Le position du soi est une verité qui se fixe à elle-même".

39 "Ce point ne peut être comprise comme la réflexion apparaît comme un retour à la prétendue preuve de la conscience immédiate".

40 Cfr. em RICOEUR, 1996, p.140: Quando tratamos Lecture 2, "Retour à Hegel".
} 
Ora, porque é que a posição do ego deve ser reaprendida através dos seus atos? Precisamente porque ela não é dada nem numa evidência psicológica, nem numa intuição intelectual, nem numa visão mística. Uma filosofia reflexiva é o contrário de uma filosofia do imediato. A primeira verdade - eu sou, eu penso - permanece tão abstrata e vazia quanto ela é invencivel. Precisa ser "mediatizada" pelas representações, pelas ações, as obras, as instituições, os monumentos que a objetivam.

Ao tomar a reflexão neste sentido, nos vimos impedidos de dizer que a filosofia reflexiva é a filosofia da consciência, se a consciência que nos referimos é a consciência imediata de si mesmo. E é por isso que, como dito anteriormente, Ricoeur a concebe como tarefa: "a consciência é uma tarefa, dizíamos mais acima, mas ela é uma tarefa porque ela não é um dado"41.

Vejamos o que está em jogo aqui. Ricoeur reconhece o mérito de Descartes, afinal é inegável que o Si tenha percepção de si mesmo e de seus atos, o que de certa forma é uma evidência. Não é possível que o Si duvide de sua existência sem se perceber duvidando, existindo, e isso é uma certeza, mas não é uma certeza que possui verdade, mas sim, que é privada de verdade. Essa certeza pode ser caracterizada, como fez Malebranche, por exemplo, como um sentimento e não como uma ideia. E a partir de Kant, essa certeza é apenas uma apercepção do ego; e como apercepção, ela pode acompanhar todas as representações do si, mas essa apercepção não é conhecimento do si mesmo e não pode ser transformada em intuição. Logo, a reflexão não é intuição também (RICOEUR. Cl, 1990, p.321-322). Por fim, Ricoeur acaba opondo reflexão e intuição, ou seja, Kant contra Descartes.

Neste sentido, sabemos que a consciência é tarefa e isso porque não é dada; sabemos também que, ao duvidar da sua existência, o Si se apercebe duvidando, e isso é inegável; mas mesmo ao se aperceber - e, portanto, existindo, pois é inconcebível que algo que pensa e que duvida não exista - ainda assim, isso é apenas uma certeza privada de verdade. É um sentimento, o Si sente que existe e que pensa, e isso é que chamou Kant de apercepção, mas a apercepção

${ }^{41}$ Cfr. em RICOEUR. CI, 1990, p.321: "La conscience est une tâche, nous l'avons dit ci-dessus, mais il est une tâche parce qu'il est un pas donné". 
não é conhecimento de si. Logo, a reflexão é afastada do conhecimento de si por Kant e sua crítica à "psicologia racional".

Deste modo, se a reflexão não é conhecimento de si, também não é intuição, mas não podemos associá-la a uma mera crítica do conhecimento. Neste sentido, Ricoeur concorda com Fichte e Jean Nabert, ao afirmar que "a reflexão é menos uma justificação da ciência e do dever, do que uma reapropriação do nosso esforço para existir" "2. Certamente, a reflexão visa "igualar a minha experiência concreta à posição: eu sou. [...] a posição do si não é um dado, é uma tarefa; ela não é gegeben, mas aufgegeben" 43 .

A dialética não é, portanto, somente compreendida no sentido metodológico, mas também num sentido mais amplo, a saber: o sentido antropológico, como ação humana. E neste sentido é tomada como símbolo, como texto, ação e tradução. Por isso, defendemos que o que há de mais singular na obra de Ricoeur é de fato a sua dialética, mais precisamente naquilo que ela propõe uma mediação imperfeita. E que essa preocupação com 0 imediato e 0 mediado, essa justificação de uma mediação, perpassa toda a sua vasta obra, desde os seus primeiros escritos, desde Karl Jaspers et la philosophie de l'existence (1947) até a sua última obra publicada postumamente Vivant jusqu'à la mort suivi de Fragments (2007).

A mediação imperfeita de Ricoeur não é mais uma autorreflexão do Absoluto, como pretendeu Hegel, pois ela pertence ao homem. Ela representa a saída da imediatidade da consciência através da mediação dela mesma, através de seu próprio esforço, da sua reflexão, ela é uma ação existencial. Ela é uma reflexão no sentido amplo - uma tarefa da consciência, um esforço do existir - e é nesse sentido que Paul Ricoeur busca mostrar o "lugar" da dialética que, ao contrário da dialética hegeliana, não pretende ocupar todos os lugares, ou seja, não pretende abranger a totalidade, mas ao contrário, possui um lugar que está

42 Cfr. Ibid., p.322: "La réflexion moins une justification de la science et du devoir, qu'une réappropriation de notre effort pour exister".

43 Cfr. Ibid., p. 323, itálicos do autor: "Égaler mon expérience concrète à la position: je suis. [...] la position du soi n'est pas intuition ; nous disons maintenant : la position du soi n'est pas donnée, elle est une tâche ; elle n'est pas gegeben mais aufgegeben". 
situado, em último sentido, na praxis; mais precisamente, na realidade humana histórica. Acerca disso diz Ricoeur (1973, p.94, tradução nossa): "Minha tese é que se há um lugar onde as oposições produtivas podem ser observadas, reconhecidas e identificadas, este lugar é a realidade humana" 44 .

Portanto, para Ricoeur o "lugar" da dialética, da mediação, não é a totalidade, ela não está em todos os lugares, como pretendeu Hegel, mas ela está num lugar privilegiado, a saber: na realidade humana.

\section{3- 0 paradoxo sem Aufhebung}

O segundo ponto, de acordo com Ricoeur, diz respeito à Aufhebung hegeliana e o "paradoxo" herdado de Jaspers e Kierkegaard. Como dito anteriormente, Ricoeur recusa a totalização racional imposta pela dialética hegeliana. A Aufhebung hegeliana é uma lógica da razão que nos é imposta a partir do exterior, e é anterior, se não pelo progresso, ao menos pela reconciliação necessária em todos os níveis. A mediação imperfeita de Ricoeur objetiva justamente refutar tal totalização racional, o que não significa que Ricoeur concorde com o paradoxo herdado de Jaspers e Kierkegaard.

Kierkegaard insiste no paradox $0^{45}$, justamente com 0 objetivo de demonstrar que a fé não é explicada pela razão. $E$, esta última, também não serve para legitimar o saber. Logo, o saber e a fé são qualitativamente distintos. Cabe ressaltar que a fé é o paradoxo. Devemos admitir o quão difícil é descrever racionalmente o conceito de paradoxo. Ricoeur coloca em Kierkegaard et le mal, em Lectures 2:

\footnotetext{
44 "Ma thèse est que, s'il y a un lieu où des oppositions productives peuvent être observées, reconnues, identifiées, ce lieu est la réalité humaine".

${ }^{45}$ Ao retomar a dialética como método, Kierkegaard rompe com a mediação, ao considerar que nesta o indivíduo singular não tem liberdade, vontade e decisão, pois na tríade o movimento ocorre por necessidade. Estabelece a dialética da descontinuidade, por entender, que a liberdade do concretizar da existência não obedece a leis lógicas, mas a um ato de liberdade que deriva ao existente a tarefa de edificar-se a si mesmo. Esta atitude é decorrente de sua compreensão que a dialética hegeliana é abstrata e o ser que ela empreende é vazio, tanto vale para o homem, para Deus e para o estado (ALMEIDA; REDYSON, 2010, p.103).
} 
A função filosófica do paradoxo, em Kierkegaard, é próxima da função filosófica do limite em Kant; pode-se mesmo dizer que a dialética rompida de Kierkegaard tem alguma afinidade com a dialética kantiana, compreendida como crítica da ilusão. [...] Assim há algo, em Kierkegaard, que não pode ser dito sem um pano de fundo kantiano e algo, em Kant, que só adquire seu sentido por meio da luta kierkegaardiana com o paradoxo ${ }^{46}$.

Contudo, o que podemos fazer é levar o paradoxo para o limite da razão e contrastá-lo com o sistema hegeliano, que caracteriza justamente a mediação total pela razão (SHEN, 2010, p.138). A mediação Ricoeuriana se funda, justamente, sobre esse limite da razão que é próprio ao homem. Essa noção de paradoxo permite a Ricoeur explicar, se não sua impossibilidade, ao menos, sobre os limites da mediação.

Em seus estudos com Jaspers, Ricoeur irá perceber a influência de Kierkegaard em seu pensamento. Ricoeur considerará a filosofia de Jaspers sob a influência de Kierkegaard, e que esta consiste num esforço no sentido de uma "alógica", uma "objetividade rasgada", "um paradoxo", "sem Aufhebung" (SHEN, 2010, p.138 - 139). Acerca desse empreendimento de Jaspers,

[...] 0 esforço, no sentido "alógico", sem dúvida, torna-se incontestável o fato de que emerge aqui uma crítica ao saber e a objetividade ao sentido num momento positivista e hegeliano, uma objetividade superior, uma superioridade, uma objetividade sistemática rasgada; as formas do ser (serobjeto; ser-sujeito; ser em si) tem a sua própria exigência de uma dialética original onde 0 círculo, a antinomia, o paradoxo são peças centrais. Esta dialética do ser incorporada das estruturas paradoxais, irredutíveis à lógica

\footnotetext{
${ }^{46}$ Cfr. em RICOEUR. L2, 1996, p.36: "La fonction philosophique du paradoxe, chez Kierkegaard, est voisine de la fonction philosophique de la limite chez Kant; on peut même dire que la dialectique rompue de Kierkegaard a quelque affinité avec la dialectique kantienne, comprise comme une critique de l'illusion. [...] II y a ainsi quelque chose, chez Kierkegaard, qui ne peut être dit sans un arrière-plan kantien et il y a quelque chose, chez Kant, qui ne prend son sens que par le moyen de la lutte kierkegaardienne avec le paradoxe".
} 
da identidade e à lógica hegeliana, em suma, das oposições não reconciliáveis, sem Aufhebung ${ }^{47}$.

Assim, vejamos que "as oposições não reconciliáveis", "sem Aufhebung", o paradoxo, de que fala Jaspers, nos revela "a tensão da existência". O próprio Ricoeur aponta que, por vezes, adere ao pensamento hegeliano, pois a noção de paradoxo parece se sobrepor em parte a noção de "contradição de si" de Hegel.

Paul Ricoeur denuncia o fato de que o paradoxo não se deixa conduzir à reconciliação racional, a superação - como com Hegel -, o que significa que esta ainda é uma "contradição viva e não resolvida". Vejamos que o paradoxo, herdado de Kierkegaard e Jaspers, é uma "nova objetividade" que traz ainda consigo 0 fracasso dos princípios de contradição, como os da reconciliação hegeliana (RICOEUR apud SHEN, 2010, p.139).

A partir da leitura Ricoeuriana de Jaspers, podemos sinalizar que 0 pensamento do paradoxo é exprimido e, até mesmo, aprofundado pelo fracasso. A historicidade do homem se caracterizaria pela vocação para o exílio sobre a terra, uma vez que o paradoxo também exprime a inadequação radical da liberdade ao mundo e, portanto, a felicidade é impossível e a nossa vocação aqui na terra consiste apenas a escolhas entre antinomias - ou seja, não passaria da ideia de servo-arbítrio apontada por Ricoeur, no Finitude et culpabilité: L'homme faillible (1960) - onde ele [o homem] sofre de situações-limites, da limitação de suas escolhas, do conflito de consciência entre o amor, do mal estar de homem livre no Estado, etc.

De acordo com Ricoeur, Jaspers menciona que tudo parece convergir para a falha, uma vez que este concebe a liberdade somente possível por e contra a

\footnotetext{
47 Cfr. RICOEUR apud SHEN, 2010, p.139, tradução nossa: "[...] l'effort vers une 'alogique' tend incontestablement à faire émerger de la critique du savoir et de l'objectivité au sens à la fois positiviste et hégélien, une objectivité supérieure, une objectivité systématique déchirée ; les formes de l'être (être-objet, être-sujet, être en soi) ont leur nécessité propre et exigent par elles-mêmes une dialectique originale dont le cercle, l'antinomie, le paradoxe sont les pièces maîtresses. Cette dialectique de l'être incorpore des structures paradoxales, irréductibles à la logique de l'identité et à la logique hégélienne, bref, des oppositions non réconciliées, sans Aufhebung".
} 
natureza, ou ela falha enquanto como liberdade ou como ser empírico (SHEN, 2010, p.139-140).

Portanto, com base nesse paradoxo onde residem os conflitos, a mediação Ricoeuriana opera entre a "impossibilidade" e a "dificuldade". A impossibilidade da mediação total como fora proposta por Hegel e esta é uma mediação difícil para a qual somos chamados. Isto porque a dialética não é somente um princípio formal que se resume em tese, antítese e síntese, mas ela é também a reconciliação que uma vez operante mediatiza os conflitos de dois extremos. Ao contrário de Jaspers e de seu paradoxo, a mediação imperfeita de Ricoeur exige um esforço de existir e se inscreve na realidade humana, na práxis. Este é o "lugar" da mediação para Ricoeur.

Passamos agora ao terceiro ponto que evidencia a necessidade de uma mediação imperfeita.

\section{4- 0 sentido de "conservar" da Aufhebung}

A mediação imperfeita operada por Ricoeur se inscreve na noção complexa de Aufhebung hegeliana. Neste sentido, é necessário considerarmos a tradução realizada por Jean Hyppolite - que é a tradução utilizada por Ricoeur - e que a Aufhebung, de acordo com Hyppolite, significa: "suprimir", "conservar" e "elevar"48. Neste sentido, faz-se necessário evidenciarmos que Ricoeur utiliza e insiste em traduzir Aufhebung apenas como "conservar" (conserver).

Tal opção traz implicitamente a operação da mediação imperfeita com relação à teleologia e a arqueologia do si, a noção de tradição onde se sedimenta a noção do passado e a vida enquanto afirmação originária.

Aqui, traremos dois exemplos, com o objetivo de demonstrar como Ricoeur utiliza o termo "conservar" como tradução da Aufhebung hegeliana. Sendo que o primeiro exemplo consiste na crítica do filósofo endereçada a Marx, no que diz respeito à interpretação da Aufhebung nos Manuscritos. Ele critica a postura adotada por Marx que enfatiza o uso de "ultrapassar" (dépassement) e "abolir"

\footnotetext{
48 Por serem termos controversos e de difícil tradução do alemão para o francês (como faz Hyppolite) e do francês para o português (como fazemos nós), trazemos aqui os termos em francês, de acordo como foram adotados por Hyppolite, a saber: "supprimer", "conserver" e "soulever".
} 
(abolition) para a Aufhebung hegeliana e que ele se esquece do sentido de "conservar" (conserver):

Com Hegel, Aufhebung, significa a superação de uma contradição, mas uma superação, uma superação, que conserva a significação positiva do primeiro momento. De maneira que, o primeiro momento é ele mesmo essa superação. Portanto, a Aufhebung suprime e conserva a força da contradição dentro da resolução que supera o primeiro momento. 0 conceito hegeliano é muito complexo. Nos Manuscritos, portanto, não há dúvida: Aufhebung é reduzida simplesmente a abolição. De Hegel a Marx o sentido de Aufhebung se reduziu ao significado de abolição, e mais especificamente abolição prática. Com Marx, a função da Aufhebung como conservação desaparece e é substituída por uma acentuação da Aufhebung como superação unicamente. Por essa razão, nos Manuscritos, a tradução mais adequada é superação 49 .

A título de segundo exemplo, cabe ressaltar aqui que esta tradução de Aufhebung de Hyppolite que segue Ricoeur é diferente da tradução de Derrida que, por sua vez, traduz Aufhebung como "superação" (relève). A partir desta tradução é que Derrida pensa em caracterizar o sistema hegeliano e assim ele critica o logocentrismo. Podemos dizer que Derrida se juntou à versão de Marx, traduzindo Aufhebung por "superação", em um duplo sentido: "substituir" (remplacer) e "elevar" (élever).

O sentido de "suprimir" tem muito menos realce com Ricoeur do que com Derrida. Mas cabe salientar que isso não significa que Derrida tenha compreendido

49 Cfr. em RICOEUR. IU, 1997, p.83, tradução nossa: "Chez Hegel, Aufhebung veut dire le dépassement d'une contradiction, mais un dépassement, une suppression, qui conserve la signification positive du premier moment. Dans son dépassement, le premier moment devient ce qu'il est. Donc, Y Aufhebung à la fois supprime et conserve la force de la contradiction à l'intérieur même de la résolution qui dépasse le premier moment. Le concept hégélien est très complexe. Dans les Manuscrits, par contre, il n'y a aucun doute : Aufhebung veut dire simplement abolition. De Hegel à Marx, le sens de $Y$ Aufhebung se réduit jusqu'à signifier abolition, et plus spécifiquement abolition pratique. Chez Marx, le rôle de $Y$ Aufhebung comme conservation disparaît et il est remplacé par une accentuation de $Y$ Aufhebung comme suppression uniquement. Pour cette raison, dans les Manuscrits, la traduction la plus adéquate est suppression". 
mal o significado da Aufhebung hegeliana, ocorre que o destaque dado por Hegel ao sentido de "conservar" na Aufhebung não é tão evidente em todo o seu trabalho. Por vezes, Hegel salienta o sentido de "conservar" para a Aufhebung e em outros momentos ele a reduz a "superar" e a "suprimir" (SHEN, 2010, p.142).

Abordaremos, ainda que brevemente, o diálogo entre Derrida e Ricoeur, no quarto capítulo desse estudo, na seção que trata do segundo momento da mediação imperfeita, acerca da metáfora e do sentido.

Ricoeur. em Renoncer à Hegel, critica a filosofia hegeliana da história pela noção de "sem Aufhebung". Ele refuta o caráter totalizante da filosofia da história, e a noção de eterno presente onde está ancorada a Razão divina da história, assim como também a noção de passado ultrapassado. Com a noção de passado ultrapassado, o sentido de "conservar" da Aufhebung assume uma posição à margem na filosofia hegeliana da história. E é justamente, neste sentido, com a noção de "conservar" da Aufhebung e a noção de "passado" que Ricoeur analisa e critica a noção do passado ultrapassado de Hegel.

Após refutar Hegel, como demonstramos no segundo capítulo deste estudo, quando tratamos da "terceira tentação hegeliana", Ricoeur coloca:

Tendo Hegel sido abandonado, pode-se ainda pretender pensar a história e o tempo da história? A resposta seria negativa se a ideia de uma "mediação total" esgotasse o campo do pensar. Resta outra via, a da mediação aberta, inacabada, imperfeita, ou seja, uma rede de perspectivas cruzadas entre a expectativa do futuro, a recepção do passado, a vivência do presente, sem Aufhebung numa totalidade em que a razão da história e sua efetividade coincidiram ${ }^{50}$.

Quanto à noção de "conservar" que Ricoeur utiliza da Aufhebung hegeliana, ela se diferencia da negatividade radical, por sua potência afirmativa. E, também,

\footnotetext{
50 Cfr. em RICOEUR.TR3, 2012, p.352: "Hegel quitté, peut-on encore prétendre penser l'histoire et le temps de l'histoire ? le réponse serait négative si l'idée d'une « médiation totale » épuisait le champ du penser. Demeure une autre voie, celle de la médiation ouverte, inachevée, imparfaite, à savoir un réseau de perspectives croisées entre l'attente du futur, la réception du passé, le vécu du présent, sans Aufhebung dans une totalité où la raison de l'histoire et son effectivité coïncideraient".
} 
"os seus conteúdos e estratégias das contradições produtivas" ${ }^{1}$. Portanto, 0 sentido "conservar" se inscreve na contradição produtiva. Para Ricoeur, ainda que "conservar" se inscreva na contradição produtiva, ele não adota uma visão muito positiva, porque acredita que, apesar de estar num estágio mais elevado, ainda é possível que se seja atingido pelo mal (SHEN, 2010, p.143).

Ricoeur demonstra, no artigo Le paradoxe politique, que um maior mal é possível por uma maior razão, a instituição política. 0 mal político do passado é "conservado" e elevado ao invés de ser suprimido. Contudo, ele pode também ser ignorado à medida da efetuação da Razão histórica, uma vez que o bem é garantido pela Razão divina que guia o destino da história.

A partir da filosofia hegeliana da história é possível perceber que o sentido de "conservar" da Aufhebung não é utilizado de forma homogênea por Hegel, e nem sempre na sua forma positiva e produtiva, mas Ricoeur o utiliza implicitamente para pensar a obra de Hegel.

Contudo, para a mediação imperfeita operada por Ricoeur, o sentido de "conservar" se faz extremamente importante, porque é ele que permite uma visão positiva do passado, que permanece no presente e no futuro, ao invés de ser suprimido.

\section{5- A mediação imperfeita e a oposição produtiva}

Diante dos conflitos de opostos somos impelidos a buscar uma solução. Os conflitos têm lugar no movimento, são processos dinâmicos. Por isso, é necessário que se encontre uma solução para tais conflitos. Uma mediação, uma dialética entre os opostos que tenha efeitos produtivos. Por isso, o quarto ponto indicado por Ricoeur para demonstrar o "lugar" da dialética refere-se à oposição produtiva.

O que diferencia a mediação de um dualismo é justamente a oposição produtiva. No dualismo, nós também temos conflitos entre duas realidades opostas, mas não existe a possibilidade de uma mediação, porque ambas são irredutíveis. $O$ que permite a solução dos conflitos é justamente a "oposição

51 Cfr. em RICOEUR. DA, 1989, p.298-299: "les contenus et les stratégies des contradictions productives". 
produtiva", do contrário, cairíamos no dualismo, no paradoxo. É a "oposição produtiva" que nos possibilita a saída imediata do estado de conflito, que é opaco e abstrato, para que se busque o sentido para retornar ao concreto.

Portanto, o imediatismo é apenas o ponto inicial, de partida, para uma reflexão mais elaborada, dialética, através da "oposição produtiva", e não apenas do ponto de vista metodológico, mas também, existencial, histórico e ético.

A mediação imperfeita de Ricoeur permite que, através da "oposição produtiva", se saia do conflito, e que seja possivel uma solução, evitando-se a natureza e a lógica. Uma solução situada na realidade humana e não apenas na reflexão especulativa.

Embora a mediação imperfeita proposta por Ricoeur recuse 0 saber absoluto e a totalização racional, podemos mostrar ao menos três pontos de aproximação entre os dois projetos dialéticos, a saber: ambos acreditam ser necessária a mediação, ambos recusam a permanência na dicotomia não resolvida e, também, ambos têm uma visão teleológica, embora o projeto hegeliano busque o saber absoluto e o projeto Ricoeuriano busque a alteridade, "viver bem com e para os outros em instituições justas"52.

De acordo com Ricoeur:

A hipótese da dialética se inscreve em dois tipos de oposição descritos por Kant em 'Ensaio para introduzir a noção de grandezas negativas em filosofia'. Se a dialética tem um sentido, um terceiro tipo de oposição, deve ser assumido que ela pode chamar-se oposição produtiva, significando assim uma oposição que, de uma forma ou outra, permite, favorece e engendra uma coisa nova, na realidade ou experiência, qualitativamente distinta dos termos opostos. Deve ser entendido que esses dois caracteres não são outra coisa do que os critérios de identificação que não podem ser transformados em aspectos formais, sob pena de contradizer o caráter fundamental da dialética [...] a saber de proceder apenas do movimento dos mesmos conteúdos ${ }^{53}$.

\footnotetext{
52 Cfr. em RICOEUR. SA, 1991, p.202: "Vie bonne' avec et pour autrui dans des institutions justes".

53 Cfr. em RICOEUR, 1973, p.92, tradução nossa: "L'hypothèse de la dialectique s'inscrit donc en dehors des deux sortes d'opposition décrites par Kant dans 'Essai pour introduire en philosophie le
} 
A visão progressiva da dialética nos remete a uma teleologia. E, neste sentido, cabe aqui destacar o De l'interprétation, essais sur Freud (1966), onde Ricoeur compara as figuras da consciência às figuras do espírito na Fenomenologia do espírito de Hegel.

O que Ricoeur propõe é que a arqueologia freudiana permaneça abstrata enquanto não for compreendida:

Numa relação de oposição complementar com uma teleologia, isto é, com uma composição progressiva de figuras ou de categorias, onde o sentido de cada uma é esclarecido pelo sentido das figuras ou das categorias ulteriores, segundo o modelo da fenomenologia hegeliana ${ }^{54}$.

Dito isso, Ricoeur aponta que a filosofia da ação não encontra solução satisfatória por parte da fenomenologia de Husserl ou da filosofia analítica. E isso ocorre porque nem a filosofia analítica nem a fenomenologia de Husserl tinham conhecimento de algumas categorias básicas da ação humana, por se deterem na abordagem puramente descritiva e analítica. Diante disso, o filósofo nos propõe que se chame de práxis, ao invés de ação, os recursos que são justamente de tratamento dialético. E ainda que uma filosofia da práxis comece onde a fenomenologia e a análise linguística pararam (RICOEUR, 1973, p.95).

Torna-se evidente a ênfase dada por Ricoeur à "oposição produtiva". Ela pode ser caracterizada como um esforço para a reconciliação que recusa permanecer num antagonismo sem solução. $O$ que não pode ser compreendido

concept de grandeur négative.' Si la dialectique a un sens, une troisième sorte d'opposition doit être supposée, que l'on peut appeler une opposition productive, en entendant par là une opposition qui, d'une manière ou d'une autre, permet, favorise ou engendre une chose nouvelle, dans la réalité ou dans l'expérience, qualitativement distincte des termes opposés. II doit être entendu que ces deux caractères ne sont pas autre chose que des critères d'identification qui ne sauraient être transformés en traits formels, sous peine de contredire le caractère fondamental de la dialectique [...] à savoir de ne procéder que du mouvement même des contenus".

54 Cfr. em RICOEUR. DI, 1977, p.282: "Dans un rapport d'opposition complémentaire avec une téléologie, c'est-à-dire avec une composition progressive de figures ou de catégories, où le sens de chacune s'éclaire par le sens des figures ou des catégories ultérieures, selon le modèle de la phénoménologie hégélienne". 
também como se a produtividade da dialética seja ilimitada. Ocorre que é necessário que a reconciliação se dê no âmbito da intencionalidade sem aboli-la.

Uma vez tratados os quatro pontos indicados pelo Ricoeur, que visaram demonstrar qual o "lugar" da sua dialética, ou seja, da mediação imperfeita, cabe assegurar que se a mediação imperfeita de Ricoeur consiste, como já dissemos antes, na renúncia ao saber absoluto hegeliano e que possui um caráter teleológico, que visa como télos, a alteridade, ou dito de outra forma, a "perspectiva ética". Também é necessário mencionar que, de acordo com a tese apresentada pelo filósofo em seu artigo Le 'lieu' de la dialectique (1973), o "lugar" da mediação imperfeita, uma vez renunciada a lógica e a natureza, é, sem dúvida, a realidade humana (RICOEUR, 1973, p.94), pois é na realidade humana ${ }^{55}$ que a oposição produtiva pode ser observada, reconhecida e identificada.

Quando tratamos do primeiro ponto - dos quatro pontos -, que indicam o "lugar" da dialética Ricoeuriana em sua obra, mencionamos que Ricoeur aponta em seu artigo Le 'lieu' de la dialectique (1973) três momentos distintos da mediação imperfeita. Assim, trataremos de forma detalhada de cada um deles no próximo capítulo deste estudo. Contudo, parece-nos conveniente salientar aqui que os três momentos da mediação imperfeita tratados a seguir, são a partir do referido artigo, que fora publicado no ano de 1973. Assim, procuramos através do cotejamento dos textos e obras do filósofo identificar onde ele estava operando com tal mediação. Procurando identificar alguns exemplos para cada momento, 0 que não significa que estes esgotem todas as aplicações do referido marco teórico do filósofo.

\footnotetext{
55 "Ma thèse est que, s'il y a un lieu où des oppositions productives peuvent être observées, reconnues, identifiées, ce lieu est la réalité humaine" (RICOEUR, 1973, p.94).
} 


\section{A MEDIAÇÃO IMPERFEITA EM TRÊS MOMENTOS}

Paul Ricoeur em seu artigo intitulado Le 'lieu' de la dialectique (1973) distingue três momentos da dialética: i) o momento da dialética do 'desejo racional', da vontade; ii) do espírito subjetivo; iii) da transição da vontade subjetiva à vontade objetiva. Essa divisão proposta por Ricoeur revela a tensão de um conflito de opostos e ultrapassagens. Trataremos de cada um desses momentos no capítulo quatro.

Ricoeur rejeita a totalização, a pretensão do Saber Absoluto de Hegel, mas não rejeita a mediação. A mediação de Ricoeur é aquela que tem como lugar a realidade humana. Como dito anteriormente, a mediação de Ricoeur não é aquela que prioriza a negatividade como a de Hegel, mas aquela que prioriza a alteridade.

Os três momentos da mediação de Ricoeur que trataremos a seguir possuem, ao menos, uma coisa em comum, a saber: a influência de Hegel. Embora a mediação proposta por Ricoeur não seja a mesma de Hegel e, talvez, por isso, Ricoeur a chame de imperfeita, pois ela não é uma mediação perfeita e totalizante como a de Hegel, não é aquela do Saber Absoluto, mas ela foi influenciada pelo pensamento hegeliano.

\section{1- Primeiro momento: desejo racional e vontade}

O primeiro momento da mediação de Ricoeur é o momento com Freud e a psicanálise. Ricoeur fora influenciado por, Roland Dalbiez ${ }^{56}$, seu professor no

\footnotetext{
${ }^{56}$ Roland Dalbiez foi o primeiro filósofo francês a publicar uma obra sobre a psicanálise. Cfr. Dalbiez, Roland. La Méthode psychanalytique et la doctrine freudienne, dois volumes, Paris, Desclée de Brouwer\&Cie, 1936.
} 
Liceu. Desde cedo se preocupou com o problema da consciência levando em conta o involuntário, uma vez que este tem uma dimensão que escapa a consciência, a saber: o inconsciente, que the preocupava desde sua obra Le volontaire et linvolontaire (1950). Contudo, foi no ano de 1960 que escreveu seu primeiro artigo sobre Freud, Le consciente et l'inconscient ${ }^{57}$, no qual se dedicou a investigar o inconsciente.

O artigo publicado em 1960 resultou em seu livro De l'interprétation, Essai sur Freud, no qual buscou fazer uma interpretação filosófica da psicanálise freudiana com o objetivo de investigar o papel devoluto por Freud ao inconsciente (VILLELA-PETIT, 2007, p.9). Neste livro Ricoeur aborda Freud como um dos mestres da suspeita, assim como Nietzsche e Marx, que também questionaram as provas do Cogito cartesiano, da consciência. Acerca dos mestres da suspeita, Ricoeur declara: "os descobridores de máscaras" 58.

Além do problema do inconsciente, Ricoeur manifesta a sua preocupação com "os signos do homem", pois ele considera que estes não têm uma significação única e de que seja de imediato manifesta, eles precisam do trabalho de interpretação, como ele já havia mencionado em sua reflexão sobre a $L a$ Symbolique du mal. Acerca da aproximação entre as duas obras, diz Villela-Petit (2007, p.9):

No prefácio ao De l'interprétation, seu ensaio sobre Freud, Ricoeur faz aliás uma aproximação dessas duas obras, quando afirma que seu trabalho sobre Freud é "a longa trajetória pela qual retomo [ele retoma] sob novo enfoque o problema deixado em aberto ao fim de La Symbolique du mal, isto é o problema da relação entre uma hermenêutica dos símbolos e uma filosofia da reflexão concreta".

A medida que Ricoeur avança em seu trabalho, com a preocupação com o agir humano, ou seja, com a condição humana, o seu campo de investigação se

\footnotetext{
57 Este artigo encontra-se publicado em sua obra Le conflit des interprétations - Essais d'hermeneutique (1969).

${ }^{58}$ Cfr. Cl, 1990, p.100: "Les perceurs de masques".
} 
amplia. Mas, observemos que, desde Le volontaire et l'involontaire, temos presente a preocupação com a consciência imediata.

Em seu artigo Le consciente et l'inconscient (1960) Ricoeur aborda o que ele chama de "a crise da noção de consciência" e a reduz a duas proposições, a saber: i) há uma certeza da consciência imediata, mas essa não é um saber verdadeiro em si mesmo; ii) toda a reflexão remete para o irrefletido como escape intencional de si, mas este irrefletido também não é um saber verdadeiro do inconsciente (RICOEUR. Cl, 1990, p.102).

Para Ricoeur não há dúvida alguma quanto à certeza imediata da consciência. Agora, se ela é uma certeza, como ele mesmo declara, invencível, ela é duvidosa enquanto verdade. Para Ricoeur, se a vida intencional pode ter outros sentidos que não o sentido imediato. A adequação de si a si, ou seja, a consciência de si, não está no começo, mas no fim. E esta, segundo Ricoeur, é uma ideia limite. É a ideia limite de Hegel, aquela que ele chamava de saber absoluto (RICOEUR. Cl, 1990, p.102).

Embora, Ricoeur rejeite a ideia de saber absoluto de Hegel, ele concorda que ele vem no fim, ou seja, de que ele não é a situação inicial da consciência. $\mathrm{E}$, neste sentido, Ricoeur concorda com Hegel e o hegelianismo, ao menos em uma coisa: uma consciência singular não pode igualar-se aos seus próprios conteúdos. Ricoeur reconhece assim a semelhança da crítica de Hegel e de Freud.

A crítica que Hegel faz da consciência individual e da sua pretensão de se igualar aos seus próprios conteúdos é o simétrico, exato da crítica freudiana do consciente a partir da experiência analítica. Por razões inversas e concorrentes, Hegel e Freud dizem a mesma coisa: a consciência é aquilo que não pode totalizar-se, é por isso que uma filosofia da consciência é impossível (RICOEUR. Cl, 1990, p.103).

Para Ricoeur, depois de Freud não é mais possível estabelecer a filosofia do sujeito como filosofia da consciência. É preciso considerar que reflexão e consciência já não coincidem, por isso, ele declara: "é preciso perder a consciência para encontrar o sujeito" (RICOEUR, 1990, p.170). 
A certeza do Cogito como certeza imediata não é suficiente e é capaz de nos dar provas falsas. 0 Cogito, de acordo com Ricoeur, se torna um Cogito ferido. Ricoeur diz:

Mas é um Cogito injuriado que procede dessa aventura: um Cogito que se coloca, mas não se possui; um Cogito que não compreende sua verdade originária senão na e pela confissão da inadequação, da ilusão, da mentira da consciência atual59.

A partir da leitura da psicanálise freudiana de como homem sai da sua infância, se torna adulto ou consciente de si, torna-se uma problemática inevitável para a interpretação Ricoeuriana. Logo, a mesma dúvida da consciência é reconduzida a outra questão: como é que o homem sai da sua infância e torna-se adulto? (RICOEUR. Cl, 1990, p.109). E, a afirmação de Ricoeur não poderia ser diferente: continua a ser uma tarefa para a consciência. Ele diz: "a consciência não é imediata, mas mediata; ela não é uma fonte, mas uma tarefa, a tarefa de se tornar mais consciente" 60 .

A reflexão não é intuição, mas um movimento a partir do imediatismo do "eu penso" para o "eu sou", não é mais um dado ou intuição, mas sim um esforço de reflexão, um movimento no sentido de tornar-se consciente e ser adulto (RICOEUR. Cl, 1990, p.319).

Ricoeur considera necessária uma hermenêutica, uma vez que é necessário descobrir outras figuras, novos símbolos, que sejam irredutíveis àqueles que se encontram enraizados no solo libidinal. $E$ ele declara: "Depois de Freud, a única filosofia possível da consciência seria aparentada com a fenomenologia hegeliana do espírito. Nesta fenomenologia, a consciência imediata não se conhece a ela própria" (RICOEUR. Cl, 1990, p.319). Uma vez que o homem se torna adulto, se torna "consciente", quando se torna capaz dessas novas figuras

\footnotetext{
59 Cfr. DI, 1977, p.357: "Un Cogito qui se pose, mais ne se possède pas; un Cogito qui ne comprend sa vérité originaire que dans et par l'aveu de l'inadéquation, de l'illusion, du mensonge de la conscience actuelle".

${ }^{60}$ Cfr. Ibid., p.318: "La conscience n'est pas immédiate, mais médiate; elle n'est pas une source, mais une tâche, la tâche de devenir plus conscient".
} 
cuja sucessão constitui o "espírito". Essa exegese que propõe Ricoeur consiste num inventário, passo a passo das esferas de sentido que a consciência deve encontrar e que deve se apropriar também, buscando se refletir como um Si, como um Eu (moi) humano, adulto, ético. (Ibidem.).

A consciência tomada assim é apenas a interiorização desse movimento, que é encontrado na estrutura objetiva das instituições, dos monumentos, das obras de arte e de cultura. Por isso, é possível afirmar que a consciência é uma tarefa, porque ela é assegurada apenas no fim, somente no final que se "tem consciência", ou seja, que nos tornamos conscientes. E, o inconsciente é o que nos comprova que a compreensão resulta de figuras anteriores, por isso, é ele que nos puxa para trás e pode ser considerado o princípio de todas as regressões e estagnações. Essa é a condição humana. 0 consciente e o inconsciente. A dialética do voluntário e do involuntário. Ao menos, é o que nos ensina Ricoeur desde seu Le volontaire et l'involontaire (1950).

Para Ricoeur (1969), se a psicanálise é a arqueologia do sujeito, a tarefa de uma filosofia reflexiva, após Freud, é a de propiciar uma ligação dialética entre uma teleologia e a arqueologia. De acordo com Ricoeur, é apenas essa polaridade entre arché e telos, entre a origem e o alvo, que é capaz de retirar a filosofia do Cogito da abstração, do idealismo, do solipsismo, logo, de todas as formas patológicas do subjetivismo que acabam afetando e infectando a posição do sujeito. Portanto, Ricoeur acaba privilegiando mais o modelo hegeliano do que 0 husserliano, ele explica por que:

Evoco aqui um modelo hegeliano mais do que husserliano; por duas razões: primeiro que tudo, Hegel dispõe de um instrumento dialético para pensar uma ultrapassagem do nível naturalista da existência subjetiva que conserva a força pulsional inicial. Neste sentido, eu diria que a Aufhebung hegeliana, enquanto conservação do ultrapassado, é a verdade filosófica da "sublimação" e da "identificação" freudianas. Além disso, o próprio Hegel concebeu a dialética das figuras da Fenomenologia como uma dialética do desejo, sua duplicação no desejo de um outro desejo, o acesso à igualdade das consciências por meio da luta, todas estas peripécias bem conhecidas da Fenomenologia hegeliana constituem um exemplo esclarecedor, mas não constrangedor, para uma dialética teleológica do espírito enraizado na 
vida do desejo. Certamente que não se pode repetir hoje a Fenomenologia hegeliana; novas figuras do $\mathrm{Si}$ e do Espírito apareceram desde que de Hegel $[\ldots]^{61}$.

Ao confrontar Freud e Hegel, opondo a arqueologia e a teleologia, Ricoeur explora a seguinte hipótese de trabalho: "somente tem uma arché um sujeito que tem um telos" 62.

Ricoeur, assim como Merleau-Ponty, chama o empreendimento de Freud de "arqueologia do si", de acordo com Ricoeur esse não é um conceito de Freud, mas da reflexão filosófica. E ele não pretende impô-lo a Freud ou encontrá-lo na obra de Freud, mas é um conceito que ele [Ricoeur] forma a fim de compreender a si mesmo diante da leitura de Freud (RICOEUR. DI, 1977, p.343).

Inicialmente, Ricoeur (1969) considera importante confrontá-las, compreendê-las numa relação de oposição; ele opõe à marcha regressiva da análise freudiana, o método progressivo da síntese hegeliana. Contudo, depois é necessário ultrapassar esse ponto de vista, como o próprio autor reconhece e, de acordo com ele, somente quem permaneceu por bastante tempo nesse ponto tem o direito de ultrapassá-lo.

É necessário frisar que a proposta de Ricoeur não de uma integração entre a teleologia de Hegel e a arqueologia de Freud. $\mathrm{O}$ que ele pretende é encontrar um

${ }^{61}$ Cfr. em RICOEUR. Cl, 1990, p.240. Itálicos do autor; tradução nossa: "J'évoque ici un modèle hégélien plutôt que husserlien; pour deux raisons: d'abord Hegel dispose d'un instrument dialectique pour penser un dépassement du niveau naturaliste de l'existence subjective qui conserve la force pulsionnelle initiale. En ce sens, je dirais que l'Aufhebung hégélienne, en tant que conservation du dépassé, est la vérité philosophique de la "sublimation" et de "l'identification" freudiennes. En outre, Hegel a lui-même conçu la dialectique des figures de la Phénoménologie comme une dialectique du désir, son doublement dans le désir d'un autre désir, qui serait en même temps le désir d'un autre, l'accès à l'égalité des consciences par le moyen de la lutte, toutes ces péripéties bien connues de la Phénoménologie hégélienne constituent un exemple éclairant, mais non contraignant, pour une dialectique téléologique de l'esprit enracinée dans la vie du désir. Certes, on ne peut répéter aujourd'hui la Phénoménologie hégélienne ; de nouvelles figures du Soi et de l'Esprit sont apparues depuis Hegel".

${ }^{62}$ Cfr. em RICOEUR. DI, 1977, p.373: "Seul a un arché un sujet qui a un télos". 
aspecto teleológico escondido na arqueologia do si com Freud, o aspecto arqueológico escondido na teleologia de Hegel.

Cabe ainda destacar que a dialética se dá em cada sistema e não é uma dialética entre arqueologia freudiana e a teleologia hegeliana (SHEN, 2010, p.159). A proposta é de uma dialética no próprio sistema, ou melhor, em cada um dos sistemas.

$\mathrm{Na}$ descoberta freudiana do inconsciente que se revela um movimento regressivo está contida, através das noções de "identificação" e "sublimação", uma teleologia implícita. Ao mesmo tempo em que na fenomenologia hegeliana, embora esta esteja ancorada no espírito e signifique explicitamente uma "teleologia" da consciência ao espírito, ela implica uma arqueologia do si (RICOEUR. Cl, 1990, p.173-174).

Se o espírito é considerado como "um movimento objetivo das figuras do homem", isso nos indica que o espírito no sentido Ricoeuriano assume definitivamente um sentido antropológico e não revela mais um sentido absoluto, lógico-ontológico do Espírito hegeliano. Agora, Ricoeur elimina o saber absoluto do sentido do espírito, porque como ele declara, "é incompatível com a finitude do conhecimento" (RICOEUR. Cl, 1977, p.383). Incluindo-se o sentido da antropologia, o sentido do espírito é misturado com o da consciência, através do movimento. $\mathrm{E}$ isso, sim, explica a teleologia das figuras - o estoicismo, a dialética do senhor e do escravo, o ceticismo e a consciência infeliz - que retornam a si mesmo.

Vejamos o que diz Ricoeur em dois momentos distintos. Observemos inicialmente a passagem em Le conflit des interprétations:

A consciência é o movimento que aniquila sem cessar o seu ponto de partida e só está segura de si no fim. Dito de outro modo, é aquilo que apenas tem sentido nas figuras posteriores, só uma figura nova podendo revelar mais tarde 0 sentido das figuras anteriores. Assim, na Fenomenologia do espírito, o estoicismo como momento da consciência, apenas é revelado na sua significação essencial no ceticismo, enquanto que ele próprio revela o caráter absolutamente indiferente da posição do senhor e do escravo em relação à liberdade simplesmente pensada. Passa- 
se 0 mesmo com todas as figuras. Pode dizer-se de um modo muito geral que a inteligibilidade da consciência vai sempre da frente para trás ${ }^{63}$.

$\mathrm{E}$, num segundo momento, em De l'interprétation:

O espírito é aquilo que tem seu sentido em figuras ulteriores, é o movimento que aniquila sempre seu ponto de partida e se vê assegurado apenas no fim; o inconsciente significa no fundo que a inteligibilidade procede sempre das figuras anteriores, quer se compreenda essa interioridade num sentido puramente cronológico ou num sentido metafórico ${ }^{64}$.

Desta forma, Ricoeur traz à tona a arqueologia implícita de Hegel, ele se refere à consciência de si como um caso exemplar em que Hegel fala da vida e do desejo. Logo, inicialmente a consciência de si é "movimento", ou mais precisamente, ela não se refere somente a "reflexão a partir do ser do mundo sensível e do mundo da percepção e é, essencialmente, um retorno a partir do seroutro" (LIMA VAZ, 1992, p.15). Portanto, tanto a progressão e quanto o retorno são inscritos os dois na consciência de si.

O desejo, por sua vez, será explicado em função da definição da consciência de si. Para Ricoeur, o desejo absoluto colocado fora da relação, possui fora de si outro lugar, a origem da negação do tempo e da relação com 0 real. $E$, este é apenas um momento abstrato, mesmo que necessário para 0 progresso da compreensão. Dito isto, Ricoeur declara: "o desejo está desde 0 início em situação intersubjetiva"65.

${ }^{63}$ Cfr. em RICOEUR. Cl, 1990, p.113: "La conscience, c'est le mouvement qui anéantit sans cesse son point de départ et n'est assuré de soi qu'à la fin. Autrement dit, c'est ce qui n'a son sens que dans des figures postérieures, seule une figure nouvelle pouvant révéler après coup le sens des figures antérieures. Ainsi, dans la Phénoménologie de l'esprit, le stoïcisme, comme moment de conscience en tant que tel, révèle le caractère absolument indifférent de la position du maître et de l'esclave par rapport à la liberté simplement pensée ; il en est de même de toutes les figures ; on peut dire d'une façon très générale que l'intelligibilité de la conscience va toujours d'avant en arrière".

64 Cfr. em RICOEUR. DI, 1977, p.379, tradução nossa: "L'esprit, c'est ce qui a son sens dans des figures ultérieures, c'est le mouvement qui anéantit toujours son point de départ et n'est assuré qu'à la fin; l'inconscient signifie foncièrement que l'intelligibilité procède toujours des figures antérieures".

65 Cfr. DI, 1977, p.385: "Le désir est dès le début en situation intersubjective". 
A consciência de si, na Fenomenologia do espírito, é tratada como desejo, sobre isso diz Hegel (1992, p.120): "a consciência-de-si é desejo, em geral". E, sobre a constituição do sujeito, afirma Lima Vaz:

O sujeito humano se constitui tão-somente no horizonte do mundo humano e a dialética do desejo deve encontrar sua verdade na dialética do reconhecimento. Aqui a consciência faz verdadeiramente a sua experiência como consciência-de-si porque o objeto que é mediador para o seu reconhecer-se a si mesma não é o objeto indiferente do mundo mas é ela mesma no seu ser-outro: é outra consciência-de-si (1992, p.17).

Para Ricoeur, o tema do desejo se abre para o discurso da hermenêutica narrativa e remete à questão do outro, a questão do reconhecimento. Contudo, para Ricoeur, a doutrina freudiana parece insuficiente e em dissonância substancial com relação à praxis. Acontece que "Freud apresenta o ser humano como um sistema fechado sobre si, como um ovo" (BUSACCHI, 2010, p.239).

Quando tratamos a consciência como desejo, é a alteridade e a dialética teleológica que são postas em jogo, ao invés da arqueologia do desejo, o desejo é trazido gradualmente para a satisfação e o reconhecimento, como acontece na dialética do senhor e do escravo, por exemplo. Portanto, observemos que não é possível igualar o desejo hegeliano ao desejo freudiano. 0 desejo hegeliano, embora seja símbolo arqueológico, retorna a si do espírito, ainda localizado no quadro teleológico, assim que se conecta a consciência de si e, que por sua vez, se torna um desejo reflexivo, diferente hipótese de Freud de que o desejo originalmente reprimido (SHEN, 2010, p.164-165).

Sobre o conceito da consciência de si e seus três momentos, Hegel diz:

a) $\mathrm{O}$ puro Eu indiferenciado é seu primeiro objeto imediato. b) Mas essa imediatez mesma é absoluta mediação: é somente como o suprassumir do objeto independente; ou seja; ela é desejo. A satisfação do desejo é a reflexão da consciência-de-si sobre si mesma, ou a certeza que veio-a-ser verdade. c) Mas a verdade dessa certeza é antes a reflexão redobrada, a duplicação da consciência-de-si. A consciência-de-si é um objeto para a consciência, objeto que põe em si mesmo seu ser-outro, ou a diferença como diferença de nada, e nisso é independente (1992, p.125). 

manifesta:

Acerca da passagem acima da Fenomenologia do espírito, Ricoeur se

Eis por que a dialética ulterior apenas mediatizará esse imediato dado na vida, que e, como a substância continuamente negada, mas continuamente retida e reafirmada. A emergência do si não será emergência fora da vida, mas na vida. Essa posição insuperável da vida e do desejo, encontro-a em todos os níveis da dialética da duplicação da consciência de sib6.

Nota-se aqui que Ricoeur enfatiza que a emergência do si se nada na vida e não fora dela, ou seja, a mediação é manifesta na realidade humana. Portanto, parece-nos que ficou claramente demonstrado o primeiro momento da mediação imperfeita. Agora, passamos ao segundo momento, a saber: o espírito subjetivo.

\section{2- Segundo momento: o espírito subjetivo}

Este segundo momento da mediação imperfeita de Ricoeur constitui o núcleo da filosofia do "espírito subjetivo" e, que abre caminho para, o que na dialética hegeliana, se declara como "espírito objetivo" e, corresponde ao conceito Ricoeuriano de práxis, em seu sentido limitado.

Essa mediação imperfeita do segundo momento é bem conhecida dos filósofos antigos e ocasião do problema do julgamento e do erro que eles desenvolveram. Mas pela falta de um instrumento dialético eles chamaram em termos de uma "psicologia das faculdades": entendimento e vontade. Tal psicologia do julgamento e do erro fora desenvolvida pelos medievais e pelos cartesianos.

Em seu ponto mais elaborado essa psicologia atingiu o ponto ou ela pode falar da vontade como "movimento" do entendimento e o entendimento como "movimento" da vontade. A reciprocidade das ações tornou-se assim, sob as relações diferentes, o equivalente de uma ação mútua sem círculo vicioso. 0

\footnotetext{
66 Cfr. em RICOEUR. DI, 1977, p.381: "C'est pourquoi la dialectique ultérieure ne fera jamais que médiatiser cet immédiat donné dans la vie, qui est comme la substance sans cesse niée, mais sans cesse retenue et réaffirmée. L'émergence du soi ne sera pas émergence hors de la vie, mais dans la vie. [...] Cette position indépassable de la vie et du désir, je la retrouve à tous les autres niveaux de la dialectique du doublement de la conscience de soi".
} 
esquema dialético tinha apenas entrado em seu único aparelho conceitual disponível, ou seja, a ação mútua das faculdades (RICOEUR, 1973, p.97).

Para Ricoeur é possível que de uma parte, que se siga uma escala ascendente, que se possa chamar de "representação teórica", da percepção à memória e a imaginação e, de lá, ao pensamento conceitual. Mas esta escala ascendente deve, ao mesmo tempo, ser construída como um espiral enrolado em outro espiral e, consequentemente, a outra escala ascendente, assim essa "representação prática" que se eleva da necessidade de desejar, ao desejo sob a demanda, e enfim à esfera dos sentimentos propriamente humanos e das paixões, e parece que cada fase de uma espiral é tanto oposta à - e condicionada por - um estágio homologo de outro espiral. Desta maneira, podemos falar de uma promoção mútua do "teórico" e do "prático" no homem (RICOEUR, 1973, p.97-98).

O segundo momento de aplicação da mediação imperfeita realizada por Paul Ricoeur traz um diálogo entre Kant e Hegel em torno do tema da metáfora, esse diálogo anima Derrida e o próprio Ricoeur. $O$ autor de La métaphore vive (1975) irá arbitrar o debate, principalmente, com relação ao sentido exato de Aufhebung.

Há um problema entre Derrida e Ricoeur, no que tange o sentido da Aufhebung hegeliana. Como abordaremos mais adiante, Aufhebung é traduzido por Derrida por "superação" 67 e, Ricoeur por sua vez insiste, sobre o sentido de "conservar"68. Tal diferença de interpretações é importante.

No que tange o debate sobre o tratamento da metáfora com Hegel, Ricoeur assumirá como postura a defesa da idealização conceitual de Hegel em detrimento da "desconstrução" de Derrida que, por sua vez, parece perceber uma ligação entre a morte da metáfora e a Aufhebung - ou mesmo discurso filosófico.

De acordo com Shen, ainda é possível notar "uma segunda (ou mesmo terceira) dialética fragmentária operada por Ricoeur entre a poesia e a filosofia,

67 A tradução do termo "relève" (aufhebung) para o francês é bastante controversa e, não é muito diferente do francês para o português. Aqui optamos por seguir a tradução La Metaphore vive (2015), de Dion Davi Macedo, tradutor da edição portuguesa das Edições Loyola.

68 Em francês "conserver". 
que nosso autor declara serem duas disciplinas, cuja distinção e autonomia são irredutiveis" 69 .

Trata-se de uma diferença entre Derrida e Ricoeur em torno de Hegel, contudo, antes de abordarmos essa diferença, faz-se necessário abordar qual o conceito de metáfora. Tradicionalmente, a metáfora se situa dentro da retórica. Aristóteles, na Poética, define metáfora como "a transposição do nome de uma coisa para outra, transposição do gênero para a espécie, ou da espécie para o gênero, ou de uma espécie para outra, por via de analogia" (ARISTÓTELES, 1959, p.312). Ela era frequentemente utilizada pelos sofistas no período antigo, para seduzir ou persuadir.

De acordo com Shen:

Embora frequentemente a retórica tenha por função ornamentar o discurso, podemos considerar de forma positiva, que ela serve também para preencher as lacunas semânticas e responder a uma carência de domínio na linguagem cotidiana, quando esta última não nos permite mais expressar as ideias através de palavras lexicalizadas ${ }^{70}$.

De acordo com Ricoeur, em toda a metáfora, há uma comparação que ela revela e situa as coisas sob uma perspectiva e ensina a "ver como...", embora também seja uma máscara que camufla (RICOEUR. MV, 2015, p.384).

Uma vez apresentado, de forma breve, o conceito de metáfora para Ricoeur, passamos agora ao debate entre Ricoeur e Derrida ${ }^{71}$ acerca da metáfora e da idealização hegeliana. Quatro anos após a publicação de Derrida, La

69 "Soulignons encore une deuxième (voire une troisième) dialectique fragmentaire opérée par Ricoeur entre poésie et philosophie, que notre auteur déclare être deux disciplines dont la distinction et l'autonomie sont irréductibles" (2010, p.167, tradução nossa).

70 Cfr. 2010, p.167, tradução nossa: "Quoique la rhétorique ait souvent pour fonction d'orner le discours, nous pouvons considérer, de manière positive, qu'elle sert aussi à combler des lacunes sémantiques et à répondre à une carence de maîtrise dans la langue courante, quand cette dernière ne nous permet plus d'exprimer des idées à travers des mots lexicalisés".

${ }^{71}$ Acerca de esse tema ver: DERRIDA, Jacques. "La mythologie blanche". In: Revue Poétique, n.5, 1971, p.1-52. 
mythologie blanche (1971), Ricoeur escreve a sua crítica que se encontra publicada como oitavo estudo da sua obra La métaphore vive (1975).

Em 1978, Derrida escreve um texto intitulado Le Retrait de la métaphore, com o objetivo de explicar o mal entendido entre Ricoeur e ele. 0 debate gira em torno, principalmente, das relações entre a metáfora e a metafísica. Essas relações se concentram principalmente em torno da metáfora de Hegel, aquela que se encontra descrita no terceiro capítulo da segunda parte da Estética, e está no 0 Princípio de razão em Heidegger.

Derrida crê que a metáfora em Hegel se encontra ligada às coisas sensíveis, ao exterior, e se inscreve no processo de conceituação, de idealização filosófica que transporta a coisa sensível na ordem espiritual. A metáfora, enraizada na imagem, se opõe ao conceito, ou mais precisamente, ela se integra, se revela, na idealização, na conceituação (SHEN, 2010, p.169).

Se esta é a visão de Derrida, Heidegger, por sua vez, busca justificar a relação entre a metáfora e a metafísica. No primeiro texto - a Lição VI do Princípio de Razão - em que ele menciona a metáfora o faz num duplo contexto. 0 primeiro diz respeito ao quadro da discussão da sua análise anterior do "princípio da razão", presente na obra Sobre a essência do fundamento.

Neste primeiro contexto, Heidegger afirma que se pode ver (sehen) uma situação claramente e, ainda assim, não apreender (erblicken) o que está em jogo: "vemos muito e apreendemos pouco". Para Heidegger, aproximar-se do que é apreensível é escutar (hören) mais distintamente e conservar no ouvido (im Gehör behalten) certa acentuação (Betonung) determinante. Esta acentuação não permite perceber uma harmonia (Einklang) entre "é" e "razão", entre est e ratio (RICOEUR. MV, 2015, p.433-434). A tarefa, portanto, é: "O pensamento de apreender com 0 olhar aquilo que se ouve... o pensamento é uma apreensão-pelo-ouvido, que apreende pelo olhar", ou dito de outra forma: "pensar é escutar e ver" (HEIDEGGER apud RICOEUR. MV, 2015, p.434).

O primeiro contexto é constituído pela rede dos termos ver, ouvir, pensar, harmonia, que sustentam o pensamento que medita sobre a ligação entre ist e Grund na formulação do Princípio de razão. O segundo contexto se constitui pela introdução de uma interpretação em forma de objeção ("Mas nós temos pressa em 
declarar..."), diante da hipótese de um interlocutor responder: "se pensar quer dizer escutar e ver, isto pode ser apenas em um sentido figurado (übertragenen)..." (HEIDEGGER apud RICOEUR. MV, 2015, p.434).

Para Heidegger, "ouvido e vista" sensíveis são assim transpostos e retomados no domínio da percepção não sensível, isto é, do pensamento. Essa transposição é, em linguagem erudita, uma metáfora.

Nesse duplo contexto é posta a equivalência das duas transferências: a transferência metafísica do sensível ao não sensível, transferência metafórica do próprio ao figurado. Mas, a afirmação de Heidegger é ainda perturbadora: "o metafórico só existe no interior das fronteiras da metafísica" (HEIDEGGER apud RICOEUR. MV, 2015, p.435). Logo, para Heidegger, a metáfora não existe fora da metafísica. Sobre isso, Ricoeur diz:

O duplo contexto do adágio é importante: o primeiro não impõe apenas um tom de alusão e de digressão, mas um tipo de exemplo que limita de imediato o campo da discussão. De quais metáforas se trata? Quanto ao conteúdo, não se trata de modo algum de metáforas poéticas, mas de metáforas filosóficas. De imediato a filosofia, no lugar de ser posta diante de outro discurso que não 0 seu, face de metáforas produzidas pelo próprio discurso filosófico. A esse respeito, o que Heidegger faz quando interpreta filosoficamente os poetas é mil vezes mais importante que o que ele diz polemicamente, não contra a metáfora, mas contra uma maneira de chamar metáforas certos enunciados de filosofia ${ }^{72}$.

Sobre sua saída da crítica de Heidegger à "desconstrução" sem limites do Derrida, Paul Ricoeur (MV, 2015, p.439) indaga: "um pensamento mais subversivo

72 Cfr. em RICOEUR. MV, 2015, p.435: "Le double contexte de l'adage est important: le premier n'impose pas seulement un ton d'allusion et de digression, mais un type d'exemple qui limite d'emblée le champ de la discussion. De quelles métaphores s'agit-il? Quant au contenu, nullement de métaphores poétiques, mais de métaphores philosophiques. D'emblée le philosophe, au lieu d'être mis en face d'un autre discours que le sien, d'un discours qui fonctionne autrement que le sien, est en face de métaphores produites par le discours philosophique lui-même. A cet égard, ce que Heidegger fait quand il interprète en philosophe les poètes est mille fois plus important que ce qu'il dit polémiquement, non pas contre la métaphore, mais contre une manière d'appeler métaphores certains énoncés de philosophie". 
que o de Heidegger não será aquele que levantar a suspeita universal mais aguda dirigida ao não dito da própria metáfora?" $E$, responde em seguida:

Ora, o não dito da metáfora é a metáfora usada. Com ela a metaforicidade opera à nossa revelia, às nossas costas. A pretensão de manter a análise semântica em um tipo de neutralidade metafísica exprime apenas a ignorância do jogo simultâneo da metafísica inconfessada e da metáfora usada ${ }^{73}$.

O duplo contexto em que se insere Heidegger e sua crítica conduz Ricoeur à "desconstrução" sem limites de Jacques Derrida, em Mythologie blanche, e ele aponta duas afirmações de Derrida. "A primeira diz respeito à eficácia da metáfora usada no discurso filosófico; a segunda, à unidade profunda da transferência metafórica e da transferência analógica do ser visível ao ser invisível" (RICOEUR. MV, 2015, p.439).

Esta discussão de Ricoeur com Derrida em torno de Hegel a propósito da metáfora ocorre à margem daquilo que anima ambos em torno de Heidegger, suas abordagens em torno de Hegel são extremamente significativas para a nossa discussão acerca da mediação. Do seu "combate de amor" 74 com relação à metáfora e a Aufhebung de Hegel, queremos identificar a ligação implícita e sutil entre a imaginação produtiva kantiana e o idealismo alemão.

Tanto Ricoeur quanto Derrida operam uma arbitragem entre Kant e Hegel, que revela as suas atitudes radicalmente diferentes em face da filosofia ocidental e, neste caso, para o idealismo alemão. Derrida realiza uma investigação na semiologia de Hegel, a fim de demonstrar a ligação entre Kant e Hegel em torno da imaginação.

Derrida critica o fato de que a idealização filosófica, através da "superação" (Aufhebung), submete a imagem ao conceito e a repousa as margens da filosofia.

${ }^{73}$ Cfr. em RICOEUR. MV, 2015, p.439: "Or le non-dit de la métaphore, c'est la métaphore usée. Avec elle la métaphoricité opère à notre insu, derrière notre dos. La prétention de tenir l'analyse sémantique dans une sorte de neutralité métaphysique exprime seulement l'ignorance du jeu simultané de la métaphysique inavouée et de la métaphore usée".

${ }^{74}$ Conforme expressa utilizada por Karl Jaspers em Ricoeur Dufrenne no qual Jaspers fala sobre a comunicação entre a minha existência e a do outro (SHEN, 2010, p.170). 
Se a crítica da idealização se prolonga em suas reflexões sobre a metáfora na filosofia, em resposta a Derrida, Ricoeur afirma que a idealização conceitual hegeliana corresponde exatamente à submissão do esquematismo kantiano em que se trava a imaginação produtiva que a trouxe, por sua vez, ao conceito (SHEN, 2010, p.171).

Para que possamos compreender as diferenças entre as duas visões mencionadas, é necessário, primeiramente, esclarecer o que é o esquematismo kantiano; assim, faremos a análise dos textos de Derrida, a partir de Ricoeur, para que possamos observar mais um momento da mediação imperfeita operando entre o esquematismo kantiano e a Aufhebung hegeliana.

Para Kant, na Crítica da razão pura (KrV), o esquematismo designa uma das capacidades de entendimento puro durante a conceituação para resolver 0 conflito entre dois pontos heterogêneos: o conceito puro de entendimento e intuição empírica, a categoria e o fenômeno. Para que seja possível explicar a "subsunção dos fenômenos sob à categoria"75 e, por conseguinte, o retorno: "a aplicação da categoria aos fenômenos".

Acerca disso, Kant coloca:

Daremos o nome de esquema a esta condição formal e pura da sensibilidade a que o conceito do entendimento está restringido no seu uso e 0 de esquematismo do entendimento puro ao processo pelo qual 0 entendimento opera com esses esquemas (KrV, A140).

O que propõe Kant é que há um intermediário, um terceiro termo, que ele chama de "esquema", que permite mediatizar o conceito de imagem. Este esquema é a representação mediadora que é pura e transcendental, e que é de um lado intelectual, mas também sensivel de outro. Acerca do esquema como produto da imaginação, Kant afirma:

\footnotetext{
75 De acordo com Höffe, "falar em subsunção e de aplicação pode causar mal-entendidos, já que induz os intérpretes, por exemplo, Pichard e Warnock, a conceber a relação entre intuição e conceito como aquela entre o particular e o universal, ou entre um subconjunto e um superconjunto. $\mathrm{Na}$ realidade, trata-se da relação de um material indeterminado com sua forma determinante" (2005, p.111).
} 
O esquema é sempre, em si mesmo, apenas um produto da imaginação; mas, como a síntese da imaginação não tem por objetivo uma intuição singular, mas tão-só a unidade na determinação da sensibilidade, há que distinguir o esquema da imagem (KrV, A140).

Trata-se, então, de que os nossos conceitos sensíveis puros não se assentam sobre imagens dos objetos, mas sobre esquemas. Cabe dizer que a imaginação, para Kant, possui um papel transcendental. Ela exerce a função de síntese. Sobre a imaginação em Kant, afirma Terrosa (2006, p.58):

A imaginação, caracterizada por Kant, na dedução metafísica das categorias "como a função cega embora imprescindível da alma, sem a qual nunca teríamos conhecimento algum, mas da qual muito raramente temos consciência" (A 78/ B 103), é novamente definida em B 151, como "a faculdade de representar um objeto, mesmo sem a presença deste na intuição". Dado que as intuições são sensíveis, Kant concebe a imaginação como uma faculdade cuja origem está na sensibilidade, pois, trata-se de uma condição subjetiva mediante a qual podem ser dadas intuições aos conceitos puros do entendimento ou categorias. Não obstante, a sua função sintética, afirma Kant, é uma ação da espontaneidade na medida em que essa síntese é determinante, já que determina a priori o sentido em seu aspecto formal, isto, é no tempo, conforme a unidade da apercepção.

Na Crítica da razão pura, a imaginação se divide em dois tipos: imaginação produtiva e imaginação reprodutiva. Logo, a imaginação produtiva é aquela:

Responsável por aquela síntese espontânea, transcendental, que determina a sensibilidade em "conformidade com as categorias» (B151-152). Ao contrário, a imaginação reprodutiva está «submetida a leis meramente empíricas, as da associação, e não contribui, portanto, para 0 esclarecimento da possibilidade de conhecimento a priori» (SEHNEM, 2009, p.40).

Acerca dos esquemas, Kant e afirma:

Os esquemas não são, pois, mais que determinações a priori do tempo, segundo regras; e essas determinações referem-se, pela ordem das 
categorias, respectivamente à série do tempo, ao conteúdo do tempo, à ordem do tempo e, por fim, ao conjunto do tempo no que toca a todos os objetos possíveis ( $\mathrm{KVV}, \mathrm{B} 185)$.

Portanto, para o esquematismo, notamos que a imaginação tem por tarefa explicar o fato que o conhecimento humano pressupõe uma capacidade de síntese do heterogêneo por uma temporalização de entendimento em que aquela imagem e o conceito estão ligados (SHEN, 2010, p.172-173).

Uma vez esclarecido no que se constitui o esquematismo kantiano, tentaremos resumidamente apresentar como Jacques Derrida une a semiótica hegeliana, ancorada na Aufhebung, ao objetivo de introduzir a questão da metáfora. Nesse sentido, passamos ao artigo intitulado Le puits et la pyramide de Derrida.

Neste artigo, Derrida aborda a semiótica hegeliana na Fenomenologia do espírito e, em particular, na seção do espírito objetivo em que Hegel trata do signo em seu capítulo intitulado "Imaginação". Derrida constata que de Aristóteles até Sausurre, o signo se inscreve na psicologia. Com Hegel, o signo supera a imaginação que é uma etapa da representação designante, "o próprio da inteligência". E isso gera mudanças em cada etapa, da interior à exterior, das imagens inconscientes aos signos fantásticos até os conceitos.

Hegel distingue a imaginação reprodutiva, aquela que mostra a passividade da impressão; da imaginação produtiva, que assinala a criação ou a expressão espontânea (SHEN, 2010, p.174). Para Derrida, o conceito de imaginação produtiva é fundamental na Estética de Hegel. Derrida (1972, p.91) declara: "0 movimento da imaginação transcendental é o movimento da temporalização: Hegel reconhece o elo essencial entre a imaginação produtiva dos signos e o tempo"76.

Cabe destacar que para Derrida, com Hegel, "o signo é a superação da intuição sensível-espacial"77. O papel do signo com Hegel nos indica a unidade da significação entre significante e significado e, também, a passagem da espera do

\footnotetext{
76 "Le mouvement de l'imagination transcendantale est le mouvement de la temporalisation: Hegel reconnaît le lien essentiel entre l'imagination productrice des signes et le temps".

${ }^{77}$ Cfr. DERRIDA, 1972, p.102: "Le signe est la relève de l'intuition sensible-spatiale".
} 
ser revelado pela inteligência. A inteligência, para Derrida, é o poder que produz um signo ao negar a espacialidade sensível da intuição, como é demonstrado, por Hegel, na superação (Aufhebung) do espaço e do tempo. O signo torna-se um ser temporalizado que nega a espacialidade, porque a supera (SHEN, 2010, p.175176).

Dito isso, percebe-se que a subsunção das instituições sensiveis sob a categoria de espaço é realizada pela Aufhebung hegeliana. Logo, são essas percepções de Derrida sobre a semiótica de Hegel, nas quais se destacou a ligação intrínseca entre o esquematismo e a idealização, que nos mostram o pano de fundo da sua crítica à metáfora. Por isso, consideramos importante tratar anteriormente o esquematismo kantiano e, por último, a imaginação e o signo para Hegel, a partir da interpretação de Derrida.

Agora nos concentraremos na discussão, a partir de Paul Ricoeur, acerca da superação filosófica como usura ${ }^{78}$ da metáfora.

Para Ricoeur, diante da "desconstrução" heideggeriana é necessário que se estabeleça a equação entre a usura que afeta a metáfora e o movimento de ascendência que constitui a formação do conceito para que seja possível demonstrar a eficácia da metáfora morta. E, "a usura da metáfora se dissimula na 'superação' do conceito. [...] reviver a metáfora é desmascarar o conceito" (RICOEUR. MV, 2015, p.440-441).

O texto Estética de Hegel nos mostra que os conceitos filosóficos são antes de tudo significações sensíveis transpostas (übertragen) para a ordem espiritual e, também, que a promoção de uma significação abstrata própria (eigentlich) é solidária do apagamento do metafórico na significação inicial e, desta forma, do esquecimento dessa significação, que passa de própria a imprópria.

Contudo, para Derrida, não há inovação de sentido, como vê Hegel, mas somente usura da metáfora e um movimento de idealização por dissimulação da origem metafórica. Ele diz: O movimento de metaforização (origem e depois apagamento da metáfora, passagem do sentido próprio sensível ao sentido próprio

${ }^{78}$ No original, usagées. 
espiritual por meio do desvio das figuras) não é senão um movimento de idealização (DERRIDA apud RICOEUR, 2015, p.441).

Este movimento de idealização que acaba por colocar em ação todas as oposições características da metafísica, a saber: natureza/espírito, natureza/história, natureza/liberdade, assim como sensível/espiritual, sensível/inteligível, sensível/sentido. Portanto, o conceito de metáfora pertence a tal sistema, é ele [o sistema] que descreve o espaço de possibilidade da metáfora. Para Derrida, a metáfora está situada no domínio do sensível e da imagem. A tese dele se enuncia: lá onde a metáfora se apaga, ergue-se o conceito metafísico. Derrida declara: "A metafísica apagou em si mesma a cena fabulosa que a produziu e que permanece, no entanto, ativa, turbulenta, inscrita com tinta branca, desenho invisível e oculto no palimpsesto"79.

Para Ricoeur, a eficácia da metáfora usada, que é assim substituída pela produção do conceito que apaga seu traço, tem como consequência o fato de que o próprio discurso sobre a metáfora é tomado como metaforicidade universal do discurso filosófico. Ou, dito de outra forma, há um paradoxo de autoimplicação da metáfora. (RICOEUR, 2015, p.442).

Eis o paradoxo: não há discurso sobre a metáfora que não esteja numa rede conceitual metaforicamente engendrada. Logo, não há campo metafórico, uma vez que a metáfora se diz metaforicamente. Portanto, de acordo com Derrida, o projeto de decifrar a figura do texto filosófico acaba por destruir a si mesmo, e é essa condição de impossibilidade deste projeto. Se, por acaso, fosse possível ordenar as figuras, ao menos uma metáfora escaparia: a metáfora da metáfora.

Ricoeur apresenta suas observações críticas, principalmente com relação à argumentação que é extraída da metáfora usada e, também, do tema metafísico. Ele coloca a impossibilidade da metáfora usada; para ele, as metáforas mortas não são mais metáforas, mas se juntam à significação literal para ampliar a polissemia (RICOEUR. MV, 2015, p.446).

\footnotetext{
79 Cfr. DERRIDA apud RICOEUR, 2015, p.442: "La métaphysique a effacé en elle-même la scène fabuleuse qui l'a produite et qui reste néanmoins active, remuante, inscrite à l'encre blanche, dessin invisible et recouvert dans le palimpseste".
} 
Paul Ricoeur acredita que não há necessidade de uma metafísica do próprio para justificar a diferença entre o literal e o metafórico. Além do que tal distinção existe apenas graças ao conflito de duas interpretações, a saber: uma, a semântica; e a outra ao instaurar uma nova pertinência semântica que exige da palavra uma torção que lhe esgota o sentido (RICOEUR, op. cit.). Dito isso, restanos sublinhar que, para Ricoeur, bastaria uma melhor análise semântica do processo metafórico e se dissiparia a mística do "próprio", sem fazer sucumbir a metafórica também.

Acerca da renovação das metáforas extintas, assim como pretende Hegel quando entende tomar-por-verdadeiro o Wahrnehmung, assim como Heidegger entende a não ocultação em aletheia; em ambos os casos, o que faz o filósofo é criar sentido e, desta forma, produzir algo como uma metáfora viva. Logo, Ricoeur (MV, 2015, p.449) alerta que: "reviver a metáfora morta não é de modo algum desmascarar o conceito", e isso se dá por dois motivos, primeiro, porque a metáfora revivida opera de outro modo que a metáfora morta e, sobretudo, porque o conceito não tem sua gênese integral no processo pelo qual a metáfora se lexicalizou.

Acerca do texto de Hegel, é com base na noção de metáfora lexicalizada que Ricoeur repensa a relação entre a metáfora e a Aufhebung.

O texto de Hegel discutido acima não me parece justificar a tese de uma conivência entre metáfora e Aufhebung. 0 texto descreve duas operações que se cruzam entre em um lugar - a metáfora morta -, mas permanecem distintas; a primeira operação, puramente metafórica, faz de uma significação própria (eigentlich) uma significação transportada (übertragen) na ordem do espiritual; a outra operação faz desta expressão imprópria (uneigentlich) enquanto transferida uma significação abstrata própria. É esta segunda operação que é constitutiva da "supressão-conservação" que Hegel chama Aufhebung. Mas as duas operações, a transferência e a supressão-conservação, são distintas. Apenas a segunda faz do não próprio oriundo do sensível um próprio espiritual. O fenômeno da usura 
(Abnutzung) é apenas uma condição para que a segunda operação se constitua sobre a base da primeira ${ }^{80}$.

Portanto, para Ricoeur a idealização hegeliana tem como objetivo revelar um sentido de inovação a partir da metáfora morta e pensar "a vida do conceito na morte da metáfora". A usura da metáfora se inscreve na usura do sensível. É necessário ressaltar que a conversão da usura em pensamento, não é a própria usura. A reflexão se movimenta na relação entre o sensível e o conceitual da Aufhebung (SHEN, 2010, p.183). E, neste sentido, Ricoeur afirma a indispensabilidade do conceito filosófico que se desprende do sensível. Ele diz "o abandono do sentido sensível não resulta apenas em uma expressão imprópria, mas em uma expressão própria da ordem conceitual" ${ }^{81}$. Acreditamos ser oportuno citar mais uma vez a frase: "Lá onde Hegel vê uma inovação de sentido, Derrida vê somente a usura da metáfora e um movimento de idealização por dissimulação da origem metafórica"82.

Embora Ricoeur defenda a Aufhebung hegeliana, não significa que ele esteja de acordo com a ideia de saber absoluto ou o conceito que domina e mediatiza tudo. Menos ainda com a ideia de uma mediação total. Os propósitos são distintos, Derrida se ocupa do projeto hegeliano a fim de examinar a metáfora,

80 Cfr. RICOEUR. MV, 2015, p.450: "Le texte de Hegel discuté plus haut ne me paraît pas justifier la thèse d'une connivence entre métaphore et Aufhebung. Ce texte décrit deux opérations qui se croisent en un lieu - la métaphore morte - mais qui restent distinctes; la première opération, purement métaphorique, fait d'une signification propre (eigentlich) une signification transportée (ûbertragen) dans l'ordre du spirituel; l'autre opération fait de cette expression impropre (uneigentlich) en tant que transférée, une signification abstraite propre. C'est cette seconde opération qui est constitutive de la "suppression-conservation » que Hegel appelle Aufhebung. Mais les deux opérations, le transfert et la suppression-conservation, sont distinctes. La seconde seule fait du nonpropre issu du sensible un propre spirituel. Le phénomène de l'usure (Abnutzung) est seulement une condition pour que la seconde opération se constitue sur la base de la première".

81 Cfr. Op. cit.: "L'abandon du sens sensible ne donne pas seulement une expression impropre, mais une expression propre de rang conceptuel".

82 Cfr. RICOEUR. MV, 2015, p.441: "Là où Hegel voit une novation de sens, Derrida ne voit que l'usure de la métaphore et un mouvement d'idéalisation par dissimulation de l'origine métaphorique". 
enquanto que, Ricoeur, limita a pretensão de Hegel, visando encontrar certa legitimidade em sua obra (SHEN, 2010, p.183).

Como afirma Shen parafraseando Ricoeur: "Derrida entre pela porta da morte; Ricoeur pela porta da vida" ${ }^{83}$. 0 conceito de Aufhebung não é totalmente refutado por Ricoeur, ele não vê uma filosofia "sem Aufhebung", mas num sentido limitado, Aufhebung como Ricoeur defende é aquela que é capaz de garantir a autonomia, a especificidade e os limites da filosofia, onde se desenvolvem os conceitos.

Este segundo momento de aplicação da mediação imperfeita, no qual abordamos Derrida e sua discussão acerca da metáfora, nos permitiu perceber que Ricoeur pensa de outra forma Kant e Hegel, talvez, como afirmam alguns comentadores, demonstrando o seu "estilo kantiano pós-hegeliano", sendo capaz de abordar as "oposições produtivas" de Hegel e a "síntese do heterogêneo" de Kant. Neste sentido, podemos dizer que Ricoeur não abandona a ideia de espírito subjetivo de Hegel, mas nega o saber absoluto. Como já afirmamos anteriormente, a mediação imperfeita proposta por Ricoeur, nega a ideia de saber absoluto.

Passamos agora ao terceiro momento da mediação imperfeita, que consiste na transição da vontade subjetiva à vontade objetiva. 0 que nos permitirá abordar o espírito objetivo hegeliano e, consequentemente, um diálogo entre Husserl e Hegel a partir de Ricoeur.

\section{3- Terceiro momento: da vontade subjetiva à vontade objetiva}

Aqui apresentamos o terceiro e último momento da mediação imperfeita proposta por Ricoeur. De acordo com ele, esse terceiro momento "é a dialética por excelência" ${ }^{84}$. Os outros dois momentos a prepararam, segundo nosso autor, da mesma forma que a dialética da natureza com Hegel prepara a do espírito (RICOEUR, 1973, p.98).

Portanto, trataremos aqui da ligação entre a vontade subjetiva e a vontade objetiva. É esta mediação de uma fenomenologia com uma filosofia analítica que

\footnotetext{
83 "Derrida y entre par la porte de la mort; Ricoeur par la porte de la vie" (SHEN, 2010, p. 184).

84 "Est la dialectique par excellence" (RICOEUR, 1973, p.98).
} 
provavelmente pode falhar, na medida da limitação de uma e ou de outra, devido as suas considerações aos objetivos individuais e, assim, passar de forma silenciosa pela dimensão ética-política da vontade e da ação humanas. Com Aristóteles, a ação humana está articulada por "excelências" (arêtal) que abrangem a esfera privada e pública da ação.

A ética está ela mesma subordinada à política considerada como a ciência arquitetônica, ou do bem do indivíduo, e bem maior que é o bem público. Contudo, ao longo dos séculos, afirma Ricoeur, a totalidade aristotélica se decompôs; são dois continentes separados e distantes um do outro. De um lado, uma psicologia da decisão e do consentimento se trancou na psicologia individual, e está praticamente reduzida a teoria do julgamento evocada pelo superior. Nesta mesma medida, a ética privada restou sem relação com a política. A filosofia política migrou da filosofia da vontade para constituir uma entidade separada (RICOEUR, 1973, p.98-99).

Dito isso, Ricoeur evoca a dialética de Hegel de Princípios da Filosofia do Direito, que tem como tarefa reconstruir a totalidade quebrada, através de um "fio condutor" que é o conceito de realização da liberdade, e de reunir os membros dispersos de uma filosofia da vontade e de uma filosofia política em uma estrutura unificada que é a teoria do espírito objetivo.

Neste sentido, a fim de demonstrarmos como Ricoeur opera esse terceiro momento da mediação imperfeita, passamos ao diálogo entre ele e Hegel e Husserl. Sendo este último o autor do tema da intersubjetividade e o primeiro do espírito objetivo. Tal diálogo se faz necessário porque ele permite compreender a reflexão de Ricoeur acerca da razão prática - que já tratamos no segundo capítulo deste estudo, quando mencionamos as três tentações hegelianas -, na qual convergem a Moralität kantiana e a Sittlichkeit hegeliana. E, ainda, para que seja possível compreender como Ricoeur opera a mediação com relação ao si e a sabedoria prática - que abordaremos mais adiante - e que traz a questão do trágico.

A fenomenologia de Ricoeur está fortemente ligada à fenomenologia de Husserl. Além de traduzir Idées (1950), ele escreveu alguns artigos e deu algumas entrevistas acerca da obra de Husserl, como em A l'école de la phénoménologie 
(1986). É possível que se questione porque operar uma dialética entre Hegel e Husserl? Por um lado o trabalho de Paul Ricoeur levanta questões e se coloca como um desafio, uma tarefa da fenomenologia hermenêutica que deve ser enfrentada e ultrapassada através do pensamento de Husserl; por outro, o autor visa encontrar algo de legítimo com Hegel, que seja capaz de enriquecer a iniciativa de Husserl.

Comecemos pela a experiência do outro. Paul Ricoeur assinala que Husserl é mais próximo de Hegel do que de Kant - e a sua noção de transcendental - ou até mesmo de Hume - e o seu "originário". Obviamente que Ricoeur é consciente que ambos os autores não partem do mesmo método e nem da mesma maneira de filosofar: a fenomenologia de Hegel não se inscreve na consciência, mas no espírito, enquanto que a fenomenologia de Husserl se assenta na intencionalidade da consciência.

Acerca das aproximações e afastamentos do pensamento e do método de Hegel e Husserl, Ricoeur coloca:

Hegel, na verdade, já compreendera a fenomenologia como uma inspecção ampla de todas as variedades da experiência humana (não apenas epistemológica, mas também ética, política, religiosa, estética e cotidiana). Não é, no entanto, a ela que Husserl se liga, visto que não se encontram em Husserl dois traços da Fenomenologia do Espírito: o trágico e o lógico. 0 trágico, que se deve à fecundidade do "negativo"; o lógico, que exprime a ligação necessária das figuras do espírito em um único desenvolvimento. Por isso, Husserl não faz uma fenomenologia do Espírito. O fenômeno, segundo ele, não é o aparecer de um ser capaz de ser recuperado em um saber absoluto85.

\footnotetext{
${ }^{85}$ Cfr. em RICOEUR. AP, 2009, p.7: "Hegel, il est vrai, a déjà compris la phénoménologie comme une inspection ample de toutes les variétés de l'expérience humaine (non seulement épistémologique mais éthique, politique, religieuse, esthétique et quotidienne). Ce n'est pourtant pas à elle que Husserl se rattache ; deux traits de la Phénoménologie de l'Esprit ne passent pas chez Husserl: le tragique et le logique, - le tragique qui tient à la fécondité du 'négatif', le logique qui exprime la liaison nécessaire des figures de l'Esprit dans un unique développement. C'est pourquoi Husserl ne fait pas une
} 
O diálogo entre Hegel e Husserl é acerca da problemática do outro. No sétimo capítulo de sua obra A l'école de la phénoménologie, acerca da cinquième Méditation Cartésienne, um tanto quanto longa, é a relevância desta quinta meditação, pois ela atesta a importância verdadeira do problema do outro na fenomenologia de Husserl. E, com certeza, o tema decisivo é "a apreensão 'analógica' do outro".

Para Shen, não foi o acaso que conduziu Ricoeur à Fenomenologia do Espírito em sua investigação acerca da questão do outro, da intersubjetividade, pois na época de suas pesquisas sobre o pensamento de Karl Jaspers, nos anos 1940, ele já havia percebido a importância do outro na Fenomenologia do Espírito hegeliana. E, acerca do tema da intersubjetividade, é preciso lembrar que já em sua obra De l'interprétation, ele se mostrou interessado e ciente da problemática discutida por Hegel em sua obra. O que acaba nos conduzindo ao encontro entre Freud e Hegel, proposto pelo nosso autor, quando tratou da tarefa da consciência que consistia na sucessão das figuras do espírito na busca de uma arqueologia e de uma teleologia do espírito (SHEN, 2010, p.188-189).

Como destacamos anteriormente, no primeiro momento da mediação imperfeita, quando trata acerca de Hegel e Freud, Ricoeur destaca que nessa arqueologia oculta, o espírito, ou as figuras do espírito, como compreende nosso autor, torna a descer à consciência do si e ao desejo.

Além disso, Ricoeur destaca que toda a fenomenologia do espírito não visa identificar uma fenomenologia da consciência. Mas, é necessário colocar que o lugar desta aventura:

A experiência (Erfahrung), quer dizer, o conjunto das modalidades sob as quais a consciência descobre a verdade. A fenomenologia, por conseguinte, é, de fato, esta recapitulação de todos os graus da experiência humana: aí, o homem é, sucessivamente, coisa entre as coisas, vivo entre os vivos, ser racional que compreende o mundo e age sobre ele, vida social e espiritual e existência religiosa. É neste sentido que a fenomenologia, sem ser uma

phénoménologie de l'Esprit. Le phénomène, selon lui, n'est pas l'apparaître d'un être susceptible de se récupérer dans un savoir absolu". 
fenomenologia de a consciência, é uma fenomenologia em o elemento da consciência ${ }^{86}$.

Portanto, 0 que parece reaproximar 0 espírito hegeliano da intersubjetividade husserliana, é mesmo o lugar da experiência (Erfahrung). Ricoeur faz referência ao capítulo "Espírito" da Fenomenologia do Espirito de Hegel porque neste capítulo, segundo ele, o espírito não se encontra seguro de si mesmo, não atingiu ainda a sua verdade, o absoluto; e ainda se situa na falta, na separação, na luta, na dor, na distância de si a si, no mundo da cultura onde você ainda não pode ver a intencionalidade (intentionnalite) (SHEN, 2010, p.190).

Neste sentido, Ricoeur aproxima o espírito em seus elementos e suas experiências da consciência, para se comunicar com a intersubjetividade de Husserl e o elevá-lo à dimensão institucional.

Logo, o diálogo efetuado por Ricoeur, do lado de Husserl, diz respeito à intencionalidade; é necessário que a intencionalidade "se eleve à problemática do espírito" e assim produza "uma filosofia do espírito"; da mesma forma que, por outro lado, pelo lado de Hegel, é necessário que o espírito exija "sua atualização concreta das ações, das obras e das instituições. A consciência só se torna universal ao entrar no mundo da cultura, dos costumes, das instituições, da história"87. Passamos agora a questão do si e da sabedoria prática.

Como dito anteriormente, a obra de Paul Ricoeur é conhecida por muitos pelo seu caráter "fragmentário", pelos diversos problemas abordados e pelos vários adversários com quem dialoga - como ele mesmo certa vez mencionou: não dialogou com todos os filósofos, mas escolheu os "melhores adversários" -,

86 Cfr. RICOEUR. DI, 1989, p.280: "L'expérience (Erfahrung), c'est-à-dire l'ensemble des modalités sous lesquelles la conscience découvre la vérité. La phénoménologie [hégélienne], par conséquent, est bien cette récapitulation de tous les degrés de l'expérience humaine : l'homme y est successivement chose parmi les choses, vivant parmi les vivants, être rationnel comprenant le monde et agissant sur lui, vie sociale et spirituelle et existence religieuse. C'est en ce

sens que la phénoménologie, sans être une phénoménologie de la conscience, est une phénoménologie dans l'élément de la conscience".

87 Cfr. em RICOEUR. DI, 1989, p.281: "Son actualisation concrète dans des actions, des oeuvres et des institutions. [...] La conscience ne devient universelle qu'en rentrant dans un monde de la culture, des moeurs, des institutions, de l'histoire". 
portanto, quando chegamos a célebre obra Soi-même comme un autre (1990), percebemos que seguir a ordem cronológica foi a nossa melhor escolha. Um dos motivos é que aqueles textos que tomamos de forma isolada e, que aparentemente tinham em comum apenas 0 fato de dialogarem com a filosofia hegeliana, na verdade demonstram uma dimensão maior: a dimensão do projeto filosófico Ricoeuriano, do seu marco teórico.

No nono capítulo do Soi-même comme un autre, em que Ricoeur trata a tentação hegeliana; aborda 0 si e a sabedoria prática, que constituem o terceiro aspecto da tese que governa os estudos que ele consagrou à dimensão ética do si. Temos mais um momento de recusa ao sistema hegeliano, momento em que, mais uma vez, ele apontou seus motivos para recusá-lo e, também, até onde é possível segui-lo, sem nunca esquecê-lo por completo.

Contudo, Ricoeur salienta que não é sua pretensão acrescentar à perspectiva ética e ao momento do dever uma terceira instância, aquela da Sittlichkeit hegeliana, que mencionamos anteriormente, contudo fará uso de alguns aspectos pontuais que concernem à efetuação concreta da ação sensata. Como fora demonstrado anteriormente, uma das temáticas apontadas por Ricoeur, que serve de motivação à sua recusa a Hegel é a do recurso a uma instância superior à moralidade, que põe em jogo um conceito de Espírito (Geist), mesmo que o Espírito Absoluto hegeliano seja capaz de conjugar um conceito superior, um sentido agudo da efetividade, isso foi considerado supérfluo pelo autor para a investigação que ele empreendeu neste estudo, centrada na ipseidade (RICOEUR. SA, 1991, p.281).

De acordo com Ricoeur, a passagem das máximas gerais da ação ao julgamento moral em situação só exige, a nosso ver, a renovação dos recursos da singularidade inerentes à perspectiva da verdadeira vida. E Ricoeur (SA,1991, p.282) acrescenta: "se o julgamento moral desenvolve a dialética que iremos expor, a convicção permanece a única saída disponível, sem nunca constituir uma terceira instância que precise ser acrescentada ao que nós chamamos até aqui perspectiva ética e norma moral".

Ricoeur começa seu estudo com um interlúdio, dedicado ao seu filho Olivier, que trata do trágico da ação, no qual retoma inicialmente "uma das vozes 
da não-filosofia", a saber: a tragédia grega. O filósofo destaca um dos aspectos que a tragédia Antígona, de Sófocles, pode nos ensinar a propósito da ação trágica, e que já foi destacado anteriormente pelo autor da Fenomenologia do Espirito, mais adiante ele retomará o tema a partir da perspectiva de Hegel. De acordo com Ricoeur, "a sabedoria trágica devolve a sabedoria prática à prova do único julgamento moral em situação"; ao que acrescenta: "certamente a tragédia tem realmente por tema a ação, como veremos mais adiante Hegel acentuá-la. Ela é, assim, a obra dos próprios agentes e de sua individualidade" (RICOEUR. SA, 1991, p.283; 284).

Ricoeur destaca, na tragédia grega Antígona, o quanto é carregado de sentido o modo totalmente discordante que os protagonistas traçam a linha entre amigo e inimigo, de forma que essa determinação prática não se deixa reduzir a uma simples modalidade da escolha e da deliberação tal como descrita por Aristóteles e Kant. E destaca ainda, a paixão é o que impele cada um dos dois protagonistas a chegar ao extremo e mergulhar no "fundo tenebroso de motivações que nenhuma análise da intenção moral esgota", a saber: "uma teologia, inconfessável especulativamente, a cegueira divina mistura-se de modo inextricável à reivindicação não-ambígua que cada um constrói de ser 0 único autor responsável por seus atos"88.

A escolha de Ricoeur por Antígona, segundo ele, se justifica pelo fato de que ela ensina, diz alguma coisa única no que se refere ao caráter inelutável do conflito da vida moral e, ainda traz uma sabedoria trágica - da qual falou Karl Jaspers - que ele acredita ser capaz de nos servir de guia nos conflitos de uma natureza completamente diferente e que será por ele abordada ao tratar o exemplo do formalismo em moral. Para Ricoeur (1991), o reconhecimento de si é obtido através de uma dura aprendizagem que só é adquirida no percurso de uma longa viagem através desses conflitos persistentes (de fundo agonístico da prova humana, nos quais se defrontam homem e mulher, a velhice e a juventude, a

88 Cfr. em RICOEUR. SA, 1991, p.284. Aqui cabe destacar a relação realizada por Ricœur, da passagem em Antígona: "Ai de mim! Essas desgraças, eu sou efetivamente o autor delas, e elas não poderão nunca ser lançadas sobre um outro", com sua análise do trágico em La Symbolique du mal. Philosophie de la volonté, t. II: Finitude et culpabilité, Paris, Montaigne, 1960, 1980. 
sociedade e o indivíduo, os vivos e os mortos, os humanos e o divino) nos quais se encontra uma dialética entre a universalidade e a localização, a universalidade e a subjetividade.

O objetivo de Ricoeur, a partir da tragédia, que toma por base a Antígona, é demonstrar a possibilidade de uma sabedoria trágica orientar uma sabedoria prática. E neste sentido, ele se propõe:

0 que Antígona ensina sobre a força trágica da ação foi bem percebida por Hegel na Fenomenologia do Espírito e nas Lições sobre a estética, a saber, a estreiteza do ângulo do empenho de cada um dos personagens. Talvez, seja preciso, com Martha Nussbaum, ir mais longe, num sentido que, veremos, não é tão anti-hegeliano quanto ela o crê, e discernir nos dois principais protagonistas uma estratégia de abstenção com respeito aos conflitos internos a suas causas respectivas. É sobre esse segundo ponto, mais ainda do que sobre o primeiro, que se poderá enxertar a sabedoria trágica capaz de orientar uma sabedoria prática (RICOEUR. SA, 1991, p. 286).

Ao analisar a visão de mundo dos protagonistas da tragédia, Ricoeur percebe que, tanto Creonte quanto Antígona, possuem uma visão de mundo estreita e subtraída às contradições internas, tal como percebeu Hegel. E, ainda, o filósofo alemão declara a sua preferência por Antígona ao invés de Creonte, de acordo com ele, sua escolha encontra apoio nos versos citados na Fenomenologia:

Eu não acreditava também que teu edito tivesse bastante força para dar a um ser mortal o poder de infringir os decretos divinos, que nunca foram escritos e que são inalteráveis; não é de hoje nem de ontem que eles existem; eles são eternos e ninguém sabe a qual passado remontam (ANTIGONA apud RICOEUR. SA, 1991, p. 288).

Para Ricoeur (lbid.), ao reduzir à sua exigência fúnebre essas leis nãoescritas e invocá-la para fundar sua íntima convicção, Antígona colocou o limite que denota o caráter humano, demasiado humano, de toda instituição. Para Ricoeur, a instrução da ética pelo trágico perpassa o reconhecimento desse limite. Contudo, na Antígona o trágico se revela na dimensão não-filosófica. Mas há um 
apelo a "deliberar bem" (euboulia) que atravessa a tragédia, assim como se "pensar justo" fosse a réplica para "sofrer terrivel" (RICOEUR, 1991, p.290).

Ricoeur questiona como a filosofia moral pode responder a esses apelos de "pensar justo" e "deliberar bem", uma vez que a tragédia não nos traz um ensinamento moral, ou algo do tipo, o que ela faz é trazer à tona, através da ficção, os conflitos intratáveis e não-negociáveis. Para o filósofo, a tragédia tomada como tal gera uma aporia ético-prática que se soma às demais da identidade narrativa. Contudo, para ele, uma das funções da tragédia é criar um distanciamento entre a sabedoria trágica e a sabedoria prática. A tragédia não nos oferece uma solução ao conflito, ao contrário, expõe 0 conflito e deixa para que o homem da práxis oriente novamente a ação para a solução do impasse, assumindo os riscos e os custos desta solução, no sentido de uma sabedoria prática em situação, ou seja, de uma solução que responda melhor à sabedoria trágica.

Contudo, é justamente na meditação sobre o lugar inevitável do conflito na vida moral, após a transição da catarse à convicção, no que tange a tragédia, que a meditação de Ricoeur cruza com a de Hegel. E nesse sentido, Ricoeur (1991, p. 290-291) declara:

É preciso esclarecer aqui um primeiro assunto: se devemos em alguma parte "renunciar a Hegel", não é na ocasião de seu tratamento da tragédia; porque a "síntese" que reprovamos de bom grado em Hegel se impõe a todas as divisões que sua filosofia tem o gênio de descobrir ou de inventar, não é precisamente na tragédia que ele a encontra. $E$, se alguma conciliação frágil anuncia-se, ela só recebe sentido das conciliações verdadeiras que a Fenomenologia do Espírito só encontra num estádio consideravelmente mais avançado da dialética. A esse respeito, não poderíamos deixar de observar que a tragédia só é evocada no início do vasto percurso que ocupa todo o capítulo 6 intitulado Espírito (assinalando assim que esse capitulo é homólogo a toda a totalidade da obra): a verdadeira reconciliação só advém do completo fim desse percurso, no fim do conflito entre a consciência julgadora e o homem que age; essa reconciliação repousa em uma renúncia efetiva de cada facção à sua parcialidade e adquire valor de um perdão em que cada um é verdadeiramente reconhecido pelo outro. 
Para Ricoeur, é necessária uma renúncia e um perdão por reconhecimento para que a ética perdure. É a renúncia do particular o preço a ser pago e é isso que a tragédia Antígona não nos apresenta, ela é incapaz de produzir. Portanto, os protagonistas que figuram tanto como heróis quanto como vítimas, "não se beneficiam da 'certeza de si' que é o horizonte do processo educativo no qual está empenhada a consciência de si" (RICOEUR. SA, 1991, p.291).

O tratamento dado por Hegel à Antígona nas Lições sobre estética coloca a tragédia como oposta à comédia, mas no plano dos gêneros poéticos, distanciando-a da trajetória que na Fenomenologia conduz ao "espírito certo dele próprio". Ricoeur aponta um caminho diverso do tomado por Hegel, entendendo que Hegel propusera uma solução teórica ao conflito e devesse ser saudado como subversivo relativamente à tirania e a uma razão totalitária. Para o filósofo que tem como ponto de partida uma ética das virtudes, a aristotélica (teleológica), e que depois assume os rigorismos de uma moral no estilo kantiano, é necessário que se proponha a identificar os conflitos que a moralidade acaba por suscitar no próprio nível das potências espirituais, que Hegel acredita não terem sido contaminadas pelo conflito, sendo a unilateralidade dos caráteres apenas a fonte do trágico.

0 trágico, como o concebe Ricoeur, não está à procura apenas da aurora da vida ética, mas, ao contrário, situa-se no estágio avançado da moralidade, nos conflitos que surgem no caminho e que acabam por conduzi-lo à regra do julgamento moral em situação. $E$, cabe salientar ainda que essa via é nãohegeliana, uma vez que se priva de uma filosofia do Geist (RICOEUR.SA, 1991, p.292).

A resistência de Ricoeur à uma filosofia do Geist é justamente devido à sua desconfiança comprovada acerca da Sittlichkeit, que essa filosofia do Geist exige ao colocar-se acima da moralidade; e também a desconfiança com relação à filosofia política, mais especificamente à teoria do Estado, à qual esses desenvolvimentos nos conduzirão. E aqui Ricoeur propõe a aplicação de seu marco teórico, seu método, propondo uma dialética entre ética e moralidade. Nas palavras do autor:

Minha aposta é que a dialética da ética e da moralidade, no sentido difundido nos estudos precedentes, ata-se e desata-se no julgamento moral 
em situação, sem a adjunção, em nível de terceira instância, da Sittlichkeit, florão de uma filosofia do Geist na dimensão prática. (RICOEUR, loc. cit., itálico do autor).

Para Ricoeur, a partir dessas colocações, emergem duas questões, a saber:

i) O que é que torna o conflito ético inevitável?

ii) Que solução a ação é suscetível de lhe trazer?

Após propor as questões, o filósofo responde-as. Na primeira, a resposta será: não somente na unilateralidade dos caracteres, mas os princípios morais confrontados com a complexidade da vida, são a fonte de conflitos. E, na segunda, a resposta é a seguinte: nos conflitos que suscita a moralidade, só um recurso ao fundo ético sobre o qual a moral se destaca pode liberar a sabedoria do julgamento em situação. Ele conclui: "Do phronein trágico à phronésis prática: tal seria a máxima suscetível de subtrair a convicção moral à alternativa destruidora da univocidade ou do arbitrário" (RICOEUR. SA, 1991, p.293, itálicos do autor).

Portanto, a tragédia grega Antígona ilustra o trágico da ação e é, por isso, utilizada por Ricoeur uma vez que é ela capaz de reconduzir ao formalismo moral que o filósofo considera mais essencial à ética. $O$ conflito é, sem dúvida, o ponto nefrálgico que põe em situação o si universal, a pluralidade das pessoas e 0 ambiente institucional. E, Ricoeur opta por fazer o percurso inverso do que fizer antes, começando pela instituição, depois pela pluralidade das pessoas e, por fim, mas não menos importante, tomando o si universal.

O filósofo justifica a sua escolha a partir de alguns argumentos, dos quais aponta o primeiro:

Primeira razão: trazendo a rigidez do conflito primeiramente ao plano da instituição, somos sem demora confrontados com o defensor hegeliano em favor da Sittlichkeit, essa moral efetiva e concreta que supõe admitir a substituição da Moralität, da moral abstrata, e que encontra precisamente seu centro de gravidade na esfera das instituições e na do Estado, coroando-as todas. Se conseguirmos mostrar que o trágico da ação desenvolve precisamente nessa esfera algumas de suas figuras 
exemplares, suprimiremos por aí mesmo a hipótese hegeliana quanto à sabedoria prática instruída pelo conflito. A Sittlichkeit já não designaria, então, uma terceira instância superior à ética e à moral, mas designaria um dos lugares onde se exerce a sabedoria prática, a saber, a hierarquia das mediações institucionais que essa sabedoria prática deve atravessar para que a justiça mereça verdadeiramente o título de equidade (RICOEUR. SA, 1991, p.293).

A intenção de Ricoeur é comprovar que, ao começar a tratar a questão a partir do âmbito das instituições, é possível demonstrar que o trágico da ação desenvolve precisamente aí, algumas das suas figuras exemplares. Ao comprovar isso, acaba por suprimir a hipótese de Hegel com relação à sabedoria prática instruída pelo conflito. Então, a Sittlichkeit perde o status de terceira instância superior à ética e à moral, para assumir a sua função de lugar - um dos lugares onde se exerce a sabedoria prática. Para Ricoeur, é justamente essa hierarquia, das mediações institucionais, que é necessário transpor para que a justiça, de fato, mereça o título de equidade. E, este é o primeiro motivo para tal escolha, agora vejamos o segundo:

Sendo nosso problema não acrescentar uma filosofia política à filosofia moral mas determinar os novos traços da ipseidade correspondentes à prática política, os conflitos que dependem dessa prática serviram de pano de fundo para os conflitos gerados pelo próprio formalismo no plano interpessoal entre a norma e a solicitude mais singularizante. Somente quando tivermos atravessado essas duas zonas conflituais é que poderemos nos confrontar com a ideia de autonomia que permanece, em última análise, a peça mestra do dispositivo da moral kantiana: é ai que os conflitos mais dissimulados designam o ponto de inflexão da moral com uma sabedoria prática que não teria esquecido sua passagem pelo dever (RICOEUR. SA, 1991, p.293-294).

Temos assim o segundo motivo apresentado por Ricoeur, para justificar a sua escolha, uma vez que ele não pretende acrescentar uma filosofia política a uma filosofia moral, mas determinar os novos traços da identidade narrativa (ipseidade) correspondentes à prática política. Logo, os conflitos que dependem da 
prática política, acabam por servir de pano de fundo para os conflitos gerados pelo próprio formalismo, no plano interpessoal entre norma e solicitude, ou seja, entre seguir a norma e/ou agir com solicitude (ou bondade).

Neste sentido, Ricoeur retoma a ideia de justiça, que tratara no estudo precedente (capítulo 8 de Soi-même comme un autre). Para o filósofo, a formalização que John Rawls operou não consegue resolver a equivocidade entre delimitar interesses individuais mutuamente desinteressados ou reforçar o vínculo de cooperação. No melhor dos casos, ao invés de resolvê-la, vai confirmá-la, senão, reforçá-la (RICOEUR. SA, 1991, p.294).

Acontece que Rawls acabou mascarando a equivocidade existente mediante a introdução da ideia de equilíbrio justo, que se reflete na teoria do si e da norma moral. A teoria coloca que os indivíduos em "situação original" são indivíduos racionais independentes uns dos outros, e que se preocupam em promover seus interesses respectivos, mas sem considerar os interesses dos outros. 0 alerta de Ricoeur é com relação à forma de cálculo utilitário que toma 0 maximin, se o considerarmos que os indivíduos existem separados uns dos outros.

A proposta de Ricoeur (Ibid.) é que se tome em consideração o mais desfavorecido ponto de vista como referência, desde que precisamente equilibrado por convicções bem pensadas; e esse ato de tomar em consideração está relacionado com a regra de reciprocidade, próxima da Regra de Ouro, que tem por finalidade retificar a dissimetria inicial, que se relaciona com o poder que um agente exerce sobre o paciente de sua ação, o que acaba se transformando em exploração pela violência.

Contudo, isso somente demostra o lugar do conflito, a situação realmente conflitual surge, sob a pura regra de procedimento, na diversidade entre bens distribuídos que tendem a suprimir a formulação dos dois princípios de justiça.

$O$ procedimento de distribuição acaba abolindo a diversidade das coisas a serem distribuídas, sem considerar o seu valor, a sua utilidade. E isso dá lugar a um problema de distribuição, que já fora percebido por Aristóteles, quando este tratou a justiça proporcional, uma vez que a "igualdade não se faz entre as partes, mas entre a relação da parte de um com sua contribuição diferente" (RICOEUR. 
SA, 1991, p.295). Para Aristóteles, o valor das contribuições é variável de acordo com os regimes políticos.

Para Ricoeur, ao deslocarmos o problema do processo de distribuição para a diferença entre as coisas a serem distribuídas, teremos ao menos dois problemas, sendo que muitos desses casos foram tratados após a publicação do livro de Rawls, mas que para Ricoeur são dois problemas distintos, a saber: 0 primeiro é o retorno de conceitos teleológicos que voltam a ligar o justo ao bom, através da ideia de bens sociais primeiros. Parece que para Rawls isso não é um problema, ele parece inclusive à vontade com a ideia que liga sem reservas as expectativas de pessoas representativas. $E$, ainda assim, se perguntarmos qual 0 critério que qualifica como bons os bens sociais, temos aqui um conflito, pois esses bens aparecem relativos a significações, a estimações heterogêneas.

0 segundo problema não é mais com relação à diversidade dos bens a repartir, mas com 0 caráter histórico e culturalmente determinado da estimação desses bens. Logo, aqui 0 conflito é entre a pretensão universalista ${ }^{89}$ e as limitações contextualistas da regra de justiça. Esse último problema nós não abordaremos aqui, pois Ricoeur 0 aborda ao final do estudo, acreditando que 0 conflito entre universalismo e contextualismo afeta todas as esferas da moralidade.

A preocupação de Ricoeur (1991), que aqui nos toca, é a da arbitragem que é necessária pela concorrência das esferas de justiça e pela ameaça de usurpação de uma pela outra, o que dá o verdadeiro sentido à noção de conflito social. E, é exatamente aqui que reside o perigo da tentação hegeliana, na medida em que "as questões de delimitação e de prioridade entre esferas de justiça dependem de uma arbitragem aleatória que é o plano institucional da sabedoria prática que Aristóteles chama de phronésis" (RICOEUR. SA, 1991, p.296).

É aqui, diante desta nova tentação hegeliana, que Ricoeur aplica o sistema (de Hegel), ao propor que se coloque a arbitragem do conflito entre esferas de justiça sob a categoria hegeliana de Sittlichkeit antes que sob a categoria aristotélica de phronésis.

89 "Pretensão" aqui é tomada por Ricœur no sentido positivo de reivindicação. (cf. RICOEUR.SA, 1991, p.295). 
Acerca do propósito do capítulo 8 de Soi-même comme un autre, Ricoeur diz:

Meu problema não é propor aqui uma filosofia política digna de Eric Weil, de Cornelius Castoriads ou de Claude Lefort. É somente saber se a prática política apela para os recursos de uma moralidade concreta que só encontram seu exercício no quadro de um saber de si que o Estado como tal deteria. Ai está precisamente o que ensina Hegel nos Princípios da filosofia do direito (RICOEUR. SA, 1991, p. 297, itálicos do autor).

Para Ricoeur, o conceito de direito de Hegel ultrapassaria o conceito de justiça. E ele menciona essa passagem de Hegel: "O sistema do direito, dito na introdução, é o reino da liberdade efetivamente realizada, o mundo do espírito, mundo que o espírito produz a partir dele próprio como uma segunda natureza" e acrescenta outra passagem de Hegel: "Que uma existência empírica em geral seja existência empírica da vontade, isso é que é o direito. O direito é, em consequência, a liberdade em geral, como Ideia" (HEGEL apud RICOEUR. SA, 1991, p.297).

Essa definição de direito acaba por restringir drasticamente o conceito de justiça, o campo de atuação da justiça acaba por ser reduzido. Com essa restrição a justiça acaba semelhante ao direito abstrato, cuja função maior é elevar a tomada de posse na condição de propriedade legal numa relação triangular entre uma vontade, uma coisa e uma outra vontade, o que acaba numa relação constitutiva do contrato legal (RICOEUR. SA, 1991, p.297).

O campo do contrato legal está em oposição à tradição contratualista à qual se une John Rawls, ou seja, aquela que tira o conjunto das instituições de um contrato fictício. Para Ricoeur, o que faz fundamentalmente falta no direito abstrato, "é a capacidade de ligar organicamente os homens entre eles; o direito, como o havia admitido Kant, limita-se a separar o meu do teu" (RICOEUR. SA, 1991, p.298). Essa falha, que cria um atomismo jurídico, e que afeta a sociedade inteira como sistema de distribuição - que nasce do pressuposto da situação original na fábula de Rawls - torna-se muito mais acentuada em Hegel, chegando a ser uma doença: "a pessoa jurídica fica tão abstrata quanto o direito que a 
define" (Ibid.). Aqui é possível perceber outro ponto na filosofia hegeliana que acaba por preocupar Ricoeur. E, quanto a esse vínculo contratual ele diz:

\begin{abstract}
É precisamente em oposição a esse vínculo contratual externo entre indivíduos racionais independentes e acima da moralidade simplesmente subjetiva que a Sittlichkeit define-se como o lugar das figuras do "espirito objetivo", segundo o vocabulário da Enciclopédia... E é porque a sociedade civil, lugar dos interesses em competição não cria também vínculos orgânicos entre as pessoas concretas que a sociedade politica aparece como o único recurso contra a fragmentação em indivíduos isolados (RICOEUR. SA, 1991, p. 298, itálico do autor).
\end{abstract}

Dito isso, Ricoeur enfatiza que as razões que o fazem "renunciar a Hegel" no que tange a filosofia política não são as mesmas que o fazem renunciá-lo no plano da filosofia da história90. Portanto, ele admite que somente num meio institucional específico é que as capacidades e disposições que distinguem o agir humano podem expandir-se. A partir da teoria hegeliana do direito, é preciso admitir que o indivíduo só se torna humano sob a condição de certas instituições; e nesse sentido, Ricoeur (SA, 1991, p.298-299) arremata: "se é realmente assim, a obrigação de servir a essas instituições é, ela própria, uma condição para que o agente humano continue a se desenvolver".

Para Hegel, a razão universal é que atua na história, constituindo um curso racional na história. Na medida em que evolui, essa razão se torna mais ética, passando pelas figuras parciais do Espírito - Geist - essa evolução se dá progressivamente, portanto, à medida que a razão evolui e se torna cada vez mais ética, passando do particular individual para as formas mais gerais da família, da sociedade civil e do Estado.

Ricoeur admite interpretar a teoria hegeliana do Estado como teoria do Estado liberal. E, para ele, o projeto político de Hegel não foi ultrapassado e tampouco realizado. Ao que questiona: a obrigação de servir às instituições de um Estado constitucional é de uma natureza diferente da obrigação moral de uma natureza superior? Há um fundamento diferente da ideia de justiça, último

${ }^{90}$ Como demonstrado anteriormente em sua obra Temps et récit, t. III, capítulo seis. 
segmento da trajetória da "vida boa"? E há uma estrutura normativo-deontológica diversa da regra de justiça? Ao que ele alerta:

A oposição entre a Sittlichkeit e Moralität perde sua força e torna-se inútil senão até nociva, como direi mais adiante - se, de um lado, damos à regra de justiça, por intermédio da de distribuição, um campo de aplicação mais vasto que aquele que lhe destinavam a doutrina kantiana do direito privado e a doutrina hegeliana do direito abstrato e se, por outro lado, dissociamos, tanto quanto é possível, as admiráveis análises da Sittlichkeit, da ontologia do Geist - do espírito - que transforma a mediação institucional do Estado em instância capaz de se pensar a si mesma. Separada da ontologia do Geist, a fenomenologia da Sittlichkeit cessa de legitimar uma instância de julgamento superior à consciência moral na sua estrutura triádica: autonomia, respeito das pessoas, regra de justiça. (RICOEUR. SA, 1991, p. 299-300, itálicos do autor).

Para Ricoeur, o que faz parecer que a Sittlichkeit transcende a moralidade formal é, justamente, o seu vínculo com as instituições que possuem caráter irredutível com relação aos indivíduos. Contudo, ele salienta que admitir que as instituições não procedam dos indivíduos, mas sempre de outras instituições prévias, não é o mesmo que lhe conferir uma espiritualidade distinta daquela dos indivíduos. E afirma categoricamente: "O que é inadmissível em Hegel é a tese do espírito objetivo e seu corolário, a tese do Estado erigido em instância superior dotada do saber de si" (RICOEUR. SA, 1991, p.300).

Para Ricoeur, há conflitos próprios às esferas da práxis, que podem ser separados em três níveis de radicalidade. 0 primeiro nível diz respeito ao Estado de direito em que o conflito é de regra situado nas atividades de deliberação; no segundo nível de discussão, o debate é sobre os fins do "bom" governo; e em um terceiro nível, uma indecisão, que diz respeito ao processo da própria legitimação da democracia sob a variedade dos seus modos de proceder (RICOEUR. SA, 1991, p.306).

Logo, para solucionar esses conflitos, Ricoeur acaba evocando algumas discussões importantes, tais como a de John Rawls e sua teoria da justiça, Aristóteles e seu conceito de phronésis e a equidade. E, por fim, propõe um 
diálogo entre Kant e Aristóteles, segundo ele é pelas aplicações do segundo imperativo kantiano, a saber: tratar a humanidade na sua própria pessoa e naquela de outrem como um fim em si e não somente como um meio. Temos aqui um problema de confronto entre duas vertentes éticas, uma vertente universalista $e$ uma vertente pluralista, e é disso que se ocupará a crítica do filósofo. Ricoeur (SA, 1991, p.307) coloca:

A ideia que vai guiar nossa crítica procede da sugestão feita no estudo precedente segundo a qual uma linha de divisão tenderia a separar a vertente universalista do imperativo, simbolizado pela ideia de humanidade, e a vertente que podemos dizer pluralista, simbolizada pela ideia das pessoas como fins nelas próprias. Segundo Kant, não há aí nenhuma oposição, uma vez que a humanidade designa a dignidade enquanto que as pessoas são respeitáveis, a despeito - se ousamos dizê-lo - de sua pluralidade.

A possibilidade de conflito surge porque a alteridade das pessoas, que é inerente à própria ideia de pluralidade humana, mostra-se inconciliável com a universalidade das regras que subentendem a ideia de humanidade; 0 respeito tende então a se cindir em respeito à lei e respeito às pessoas. Neste sentido, há momentos em que não é possível, em um primeiro momento, compatibilizar a universalidade das regras ao respeito à pessoa. Nessas situações a sabedoria prática pode consistir em dar prioridade ao respeito às pessoas, em nome da solicitude, que se dirige às pessoas em sua singularidade insubstituível (RICOEUR. SA, 1991, p.307).

Para Ricoeur, a sabedoria prática ou juízo prudencial é um momento que não se soma aos demais: é basicamente a compreensão de um agente moral autônomo que inventa um comportamento adequado à singularidade de cada caso, de cada situação existencial em cada contexto de ação. Logo, não é algo que deva ou possa ser generalizado, antes consiste numa situação singular que exige uma decisão igualmente singular.

Um dos resultados dessa discussão é que a noção kantiana de autonomia é enfraquecida, de forma que não pode mais ser vista como autonomia autossuficiente, como fora pensada por Kant. Essa noção acaba sendo 
enfraquecida e, em certo sentido, limitada pelas condições singulares da existência (RICOEUR. SA, 1991, p.321).

É possível perceber que Ricoeur tenta uma articulação entre as tradições aristotélica e kantiana, que em tese parecem irreconciliáveis, e uma possível complementariedade entre ambas. Inicialmente ele estabelece a primazia da ética sobre a moral, o que remarca desde o início a antecedência da perspectiva teleológica da vida boa com relação à perspectiva deontológica do que se impõe como obrigatória, ou seja, a moral kantiana.

Embora Ricoeur admita tal antecedência, isso não denota que ele pretenda demonstrar a superioridade de uma com relação à outra e, sim, demonstrar que uma é anterior à outra, mas que se faz necessária uma complementariedade entre ambas. E aqui ele aplica mais uma vez o seu marco teórico, ao propor uma dialética entre a ética (teleológica) e a moral (deontológica), ou seja, a necessidade que a perspectiva ética passe pelo crivo da norma e, contrariamente, que as normas morais, diante de impasses, conflitos e dilemas morais, passem pelo crivo da ética (ROSSATTO, 2008, p.28).

A proposta não é uma sobreposição de uma à outra, mas um entrecruzamento entre ambas, que dependendo do ângulo em que se observar, uma se sobressai diante da outra e, vice-versa, sem que ambas se tornem uma só, mas, também, que não se opte por uma em detrimento da outra. Sobre isso, argumenta Rossatto (2008, p.28):

A perspectiva ética terá de ser articulada em normas com a pretensão de validade universal e com efeito de constrangimento e obrigatoriedade; e as decisões morais, com base em valores recebidos do passado ou em novos valores incorporados, terão de ser avalizadas por um sujeito autônomo, segundo a perspectiva da vida boa.

A proposta ética de Ricoeur, de herança fenomenológica e hermenêutica, é fundada num sujeito autônomo, que se reconhece como ser finito no mundo, capaz de interpretar e reinterpretar constantemente os valores explícitos e implícitos nas narrativas vivenciadas e recebidas e, em outro sentido, nascido agora de uma 
exigência moral, esse sujeito adapta e readapta suas escolhas e liberdades pessoais aos desafios presentes ${ }^{91}$.

Portanto, a mediação operada por Ricoeur, consiste num entrecruzamento entre a ética aristotélica e a moral kantiana, o que implica em distinguir e aproximar Aristóteles e Kant, ou seja, dever e sabedoria prática. Tal mediação se dá dentro dos marcos de uma dialética hegeliana, mas renunciando a tentação de cair no Espírito absoluto, o qual reaparece nas figuras da razão moral abstrata ou de uma entidade estatal absoluta.

${ }^{91}$ Cfr. em MÖBBS, Adriane da S. M. "Respeito e casos dificeis (hard cases) em Paul Ricœur". In: Revista Guairacá, vol. 29, n.1, 2013, p.87-107. 


\section{RICOEUR: A NÃO TOTALIZAÇÃO DA SUA OBRA}

Após uma década da morte de Paul Ricoeur é notável a repercussão de suas obras tanto no Brasil quanto no mundo. Tal repercussão tem provocado algumas reflexões entre seus comentadores, no sentido de perceber o que motivou o filósofo a escrever os textos que escreveu e a se preocupar com problemas diferentes, como se eles não tivessem sequência. $O$ que permite que muitos caracterizem a sua obra como "fragmentária". Mas, há aqueles comentadores que se esforçam, alguns ainda bem antes de sua morte, em mostrar-nos um "fio condutor" ou um problema central que teria motivado as diversas abordagens de problemas, aparentemente, tão distintos quanto, aqueles com os quais ele se preocupou.

Desta discussão interessa-nos, em particular, a tese de Domenico Jervolino (1984) e a tentativa de refutação realizada por Marco Salvioli (2009). Cabe ressaltar que a tese de Jervolino fora publicada ainda quando Ricoeur era vivo.

Neste sentido, o que nos propomos, num primeiro momento, é apresentar as duas teses, suas aproximações e distanciamentos. Em seguida, porque acreditamos que a mediação imperfeita atua como "fio condutor" que unifica o símbolo, o texto, a narrativa e a tradução, mas no sentido apenas de direcionamento quanto aos problemas com quais Paul Ricoeur se ocupo durante seu percurso filosófico e não como problema central ou unidade de sua obra.

\section{1- Paul Ricoeur a partir de três paradigmas}

Entre as principais teses acerca da unidade da obra de Paul Ricoeur, podemos mencionar aquela defendida por Jervolino, que já escreveu importantes textos acerca da filosofia do autor e que também dedicou algumas linhas dos mesmos para tratar do tema da unidade da filosofia Ricoeuriana. 
$\mathrm{Na}$ tese apresentada nos anos oitenta, em seu primeiro livro sobre Ricoeur, intitulado II cogito e l'ermeneutica. La questione del soggetto in Ricoeur, de 1984, diz que a unidade da obra Ricoeuriana se assenta na questão do sujeito, que fora o tema central da modernidade filosófica. Contudo, o sujeito Ricoeuriano é entendido pelo autor como corporeidade viva e plural, como um esforço e desejo de ser, que se obtém através da reflexão e da práxis de uma vida inteira (JERVOLINO, 2004, p.660).

Jervolino (2003, p. 51), nas décadas de 70 e 80 , diz ter ocorrido uma ampliação e enriquecimento da concepção da hermenêutica de Ricoeur. Esta passa de uma fase na qual o símbolo é assumido como modelo privilegiado, para outra, na qual se torna central a noção de texto, definido como discurso fixado pela escrita; e, dentro do universo textual, a análise dos textos metafóricos e narrativos será o tema de duas grandes obras: La métaphore vive (1975) e Temps et recit (três volumes, 1983-1985). A respeito disso, Jervolino diz: "Essa distinção de fases se situa igualmente na continuidade de um projeto que atravessa toda a obra de Ricoeur e que se pode sintetizar com o título "programático" e "investigador" de fenomenologia hermenêutica [...]". (JERVOLINO, 2003, p.51).

Segundo Jervolino (2003, p.51), o projeto Ricoeuriano é sustentado por uma dupla convicção, a saber:

Por um lado, aquilo que a hermenêutica de Heidegger e de Gadamer pôs em crise não é a fenomenologia enquanto tal, mas somente a sua autointerpretação idealista, de modo que "a fenomenologia continua sendo o pressuposto insuperável da hermenêutica"; por outro lado, "a fenomenologia não pode levar a termo o seu programa de constituição sem constituir-se como interpretação da vida do ego.

É o próprio Ricoeur, sob a ótica de Jervolino, quem age com a ampliação da perspectiva de sua hermenêutica, sugerindo, de certa forma, uma periodização do seu trabalho em seu ensaio - e, posteriormente, coletânea Du texte à l'action de 1986 -, que traz como subtítulo Essais d'herméneutique II, fazendo referência a Le conflit des interprétations - Essais d'herméneutique, que fora publicado em 1969. Neste sentido, Jervolino destaca a passagem de Du texte à l'action, na qual Ricoeur reafirma as raízes reflexivas e fenomenológicas as quais pertence: "[...] 
Gostaria de caracterizar a tradição filosófica de que me reclamo, por meio de três traços: ela está na linha de uma filosofia reflexiva; permanece na esfera de influência da fenomenologia husserliana; deseja ser uma variante hermenêutica desta fenomenologia" (RICOEUR. DA, 1989, p.36).

Em um texto mais recente, La question de l'unité de l'oeuvre de Ricoeur à la lumière de ses derniers développements, datado de 2004, Jervolino afirma que sob um olhar retrospectivo ao itinerário filosófico de Ricoeur, há a tentação de se reconhecer uma lógica de desenvolvimento em espiral, o que justificaria encontrar nas suas obras tardias a sua pesquisa sobre a vontade, que inspirou seus trabalhos de juventude. Tal movimento é em espiral, e não circular, porque há 0 enriquecimento após um longo desvio através da linguagem e da textualidade. Em sua obra Introduzione a Ricoeur de 2003, Jervolino já havia apontado:

Dizemos movimento em espiral e não retorno circular às origens, pois entre o princípio e o fim não há coincidência e sim enriquecimento, após longa viagem através do universo da linguagem e da textualidade. 0 próprio Ricoeur o sugere com o título Du texte à l'action, do segundo volume dos ensaios de hermenêutica de 1986 (JERVOLINO, 2003, p.77).

Ao considerar os apontamentos de Jervolino, é necessário reconhecer que não há como admitir uma continuidade linear que liga a filosofia da vontade à hermenêutica e, posteriormente, à sua nova filosofia da vontade ou da ação.

No texto Introduzione a Ricoeur, "o fenômeno, graças ao poder revelador da linguagem, nos permite compreender os vários aspectos do homem que age e sofre" (JERVOLINO, 2004, p.661).

Neste sentido, ainda acerca da filosofia de Ricoeur e a linguagem, Jervolino acrescenta:

A filosofia de Ricoeur é mais que uma "filosofia da linguagem", é uma "filosofia através da linguagem", isto é, que através do fenômeno da linguagem em toda a sua riqueza, não esquece que é por meio da linguagem que falamos sobre algo, e que a linguagem não deve ser - senão por uma abstração deliberada e consciente - um sistema fechado em si mesmo, sem referência ao mundo e aos interlocutores do discurso: esta consideração se aplica mesmo em relação ao último trabalho, como a 
dialética entre memória e história está sempre ligada à dialética entre 0 discurso oral e discurso escrito e, portanto, o duplo trabalho de escrita e leitura (2004, p.663).

A partir dessas considerações acerca da obra Ricoeuriana, Jervolino por fim apresenta a hipótese que dá origem a sua tese:

Minha hipótese de trabalho é que pudéssemos encontrar nesta travessia da linguagem a sucessão, ao mesmo tempo, histórica (na ordem de descoberta) e teórica (numa certa ordem hermenêutica) de três paradigmas: símbolo, texto, tradução, que seriam uma espécie de bússola para se orientar durante essa longa viagem. A referência aos dois primeiros paradigmas é explicita no autor nas duas etapas de seu itinerário: hermenêutica dos símbolos, hermenêutica do texto (2004, p.663).

Neste sentido, a tese final acerca da unidade da obra de Paul Ricoeur consistiria em pensá-la a partir de três paradigmas, sendo que um deles não se sobrepõe ao outro, mas todos três se complementam. Com o objetivo de comprovar sua hipótese de trabalho, Jervolino menciona que os dois primeiros paradigmas estariam explicitamente mencionados na obra de Ricoeur, quando este divide seu trabalho em hermenêutica dos símbolos e hermenêutica do texto. O novo na composição desta tese é a indicação da tradução como o terceiro paradigma e a tentativa de articulá-los de forma sistemática.

O paradigma do texto não elimina não elimina, mas, ao contrário, complementa o paradigma dos símbolos, senão que o complementa. A introdução do terceiro paradigma, a saber, o da tradução, não contradiz os anteriores, mas os integra. Acerca disso Jervolino diz: "A progressão dos paradigmas (símbolo, texto e tradução) baseia-se numa lógica de confrontação com certos aspectos, provavelmente, da progressividade da linguagem que é a primeira pressuposição de toda a hermenêutica" (2004, p.664). E, neste sentido, complementa Jervolino:

Em primeiro lugar, direi que o paradigma do texto não elimina, mas complementa aquele do símbolo, para a introdução de um terceiro paradigma, que não contradiz os anteriores, mas completa-os. Acrescento ainda que a progressão dos três paradigmas - símbolo, texto e tradução parece obedecer à lógica do confronto com aspectos da linguagem, em 
primeiro lugar, pré-requisito antes de qualquer hermenêutica, que são, por assim dizer, de tamanho crescente (2001, p.29).

Portanto, o que são esses três paradigmas?

O paradigma do símbolo, ou seja, a manifestação do duplo ou múltiplo sentido, está relacionado ao conceito de expressão que existe no nível do signo linguístico, o que de certa forma, introduz imediatamente a dialética entre a univocidade e a pluralidade do signo, uma vez que numa linguagem totalmente unívoca não haveria espaço para o equívoco e nem mesmo para interpretar (JERVOLINO, 2004, p.664). Dentro dessa primeira fase, podemos citar as seguintes obras de Ricoeur: Finitude et culpabilité (1960), De l'interprétation Essai sur Freud (1965) e Le conflit des interprétations (1969), cujo interesse principal é a noção de "símbolo como expressão do sentido dúplice" e à definição do conceito de interpretação em função da noção de símbolo (JERVOLINO, 2003, p.41-42).

De acordo com Ricoeur:

Acreditamos que o símbolo é uma expressão linguística de duplo sentido que exige uma interpretação, a interpretação um trabalho de compreensão que visa decifrar os símbolos. A discussão crítica focará sobre o direito de procurar o critério semântico do símbolo na estrutura intencional do duplo sentido e sobre o direito de manter esta estrutura pelo objeto privilegiado da interpretação92.

O paradigma do texto, como "discurso fixado pela escrita", situando ao nível do discurso. O discurso abre caminho para a problemática da comunicação que não podemos considerar do ponto de vista filosófico como um fato apenas do

\footnotetext{
${ }^{92} \mathrm{Cfr}$. DI, 1965, p.19: "Selon nous le symbole est une expression linguistique à double sens qui requiert une interprétation, l'interprétation un travail de comprehension qui vise à déchiffrer les symboles. La discussion critique portera sur le droit de chercher le critère sémantique du symbole dans la structure intentionnelle du double senset sur le droit de tenir cette structure pour l'objet privilégié de interpretation. C'estbience qui esten question dans notre decision de delimiter l'un par l'autre le champ du symbole et celui de l'interpretation".
} 
indivíduo, mas que inclui um enigma, ou seja, aqui se encontra o problema filosófico e fenomenológico da intersubjetividade.

Comunicar através do texto compreende colocar em suspenso, entre parênteses, o vivido psíquico do autor e do leitor, um exercício quase ascético de despossessão. A dialética da univocidade e da plurivocidade é associada às dialéticas de participação e de distanciação, de apropriação e de desapropriação. Logo, 0 autor ao comunicar suspende suas intenções mentais e o mesmo acontece com o leitor, que precisa distanciar-se do texto para compreendê-lo, é uma dialética de univocidade e plurivocidade associada ao "jogo" de pertencer e distanciar-se de um texto (JERVOLINO, 2004, p.664). Nesta fase podemos citar as seguintes obras de Ricoeur: La métaphore vive (1975), Temps et récit (I, II e III, publicados entre 1983-1985) e Du texte à l'action (1986).

0 terceiro paradigma é o da tradução. Devido ao caráter enigmático e dramático da comunicação, foi preciso introduzi uma entidade nova e mais vasta do signo linguístico ou da frase que apreenda as línguas em sua diversidade histórica. É justamente essa diversidade das línguas que permite expandir a perspectiva não somente para a tradução em seu sentido estrito (entre língua e língua), mas também em seu sentido mais largo. 0 autor reconhece que dizemos, com razão, diante dos exemplos mais graves e mais intratáveis de incompreensão ou de conflito: "nós falamos duas línguas diferentes", ainda que, do ponto de vista linguístico, nós falássemos a mesma língua. Com a diversidade das línguas, portanto, é a diversidade humana sob todas as suas formas, que se introduz em nossa reflexão. Neste sentido, até mesmo a diversidade de línguas se torna paradigmática (JERVOLINO, 2004, p.664).

$\mathrm{Na}$ tradução, lidamos com os problemas da identidade e da alteridade. Nesta última fase de sua obra Ricoeur nos traz a aproximação entre o trabalho da tradução (que pressupõe a multiplicidade das línguas, mas é também modelo de toda a comunicação inter-humana) ao trabalho da memória e ao do luto, no sentido freudiano da palavra "trabalho" (JERVOLINO, 2003, p.71). Portanto, para Jervolino, o paradigma da tradução possibilita ir além do texto e da fascinação da textualidade, sem abandonar o domínio da linguagem. Acerca disso, diz Ricoeur: "Hospitalidade da língua então, onde o prazer de habitar a língua de outro é 
compensada pelo prazer de receber em sua casa, em sua própria casa, a palavra do estrangeiro" (2004, p.21).

Neste sentido, na tradução trabalhamos com o próprio e o estrangeiro, o si e 0 outro, 0 outro que nós encontramos em nós mesmos e que não se reduz à alteridade de outro indivíduo humano. Para Jervolino (2003, p.71), o conceito de hospitalidade linguística, apresentado por Ricoeur em Le paradigme de la traduction (1998), e que se torna modelo para qualquer espécie de hospitalidade, sublinha o valor ético do paradigma da tradução em vista de um novo universalismo que respeita às diferenças. De acordo com Ricoeur:

Parece, de fato, que a tradução não só representa um trabalho intelectual, teórico ou prático, mas um problema ético. Levar o leitor para o autor, levar 0 autor ao leitor, correndo o risco de servir e trair a dois mestres, se está praticando o que eu gosto de chamar de a hospitalidade linguística. É o que a torna um modelo para as outras formas de hospitalidade que eu vejo relacionadas: crenças, religiões, elas não são como línguas estranhas umas as outras, com seu léxico, a sua gramática, a sua retórica, o seu estilo, que temos que aprender a penetrar? E hospitalidade eucarística não é assumir os mesmos riscos de tradução-traição, mas também com a mesma renúncia à tradução perfeita? ${ }^{93}$.

É o próprio Ricoeur que declara ter alcançado em Soi-même comme un autre (1990) uma recapitulação do essencial da sua produção até aquele momento; e logo em seguida tem-se a publicação de Lectures (três volumes,19911994), Le juste (1995), La nature et la règle (1998), Penser la Bible (1998); e no

93 Cfr. RICOEUR, 2004, p.42, itálicos do autor, tradução nossa: "Il me semble, en effet, que la traduction ne pose pas seulement un travail intellectuel, théorique ou pratique, mais un problème éthique. Amener le lecteur à l'auteur, amener I ' auteur au lecteur, au risque de servir et de trahirdeux $m$ aîtres, c' est pratiquer ce que j ' aime appeler l'hospitalité langagière. C ' est elle qui fait modèle pour d'autres formes d'hospitalité que je lui vois apparentée: les confessions, les religions, nes ontellespascommedes langues étrangèresles unes auxautres, avecleurlexique, I eurgrammaire, leurrhétorique, leurstylistique, qu'il faut apprendre afin de les pénétrer? Et I ' hospitalité eucharistique n'est-elle pas à assumer avec les mêmes risques de traduction-trahison, mais aussi avec le même renoncement à la traduction parfaite?". 
ano 2000 temos uma nova grande obra: La mémoire, l'histoire, l'oubli, precedida de Le juste 2 em 2001 e, por fim, Parcours de la reconnaissance (2004).

Portanto, de acordo com Jervolino (2004), temos três fases na obra de Ricoeur (ou um primeiro, um segundo e um terceiro Ricoeur), o primeiro então que se situa no paradigma do símbolo, o segundo situado no paradigma do texto e, por fim, o terceiro, que compreende o paradigma da tradução.

Ao contrário do que interpretam outros intérpretes de Ricoeur, nós acreditamos que embora Jervolino aponte para três fases distintas do pensamento do filósofo francês, ele não defende que essas três fases sejam isoladas uma das outras, como etapas superadas no seu pensamento, mas que cada uma das fases se enriquece e se torna a próxima, num sentido de complementariedade, ou num "movimento espiralado".

Marco Salvioli (2009) é um dos intérpretes de Ricoeur, que se coloca contrário à tese de Jervolino, sobretudo no que tange a importância do símbolo em sua obra. Salvioli não aceita que o símbolo seja confinado apenas ao período de Finitude et culpabilité (1960), pois ele defende que o símbolo seria o "fio condutor" que perpassa toda a obra de Paul Ricoeur. Passamos à análise da tese de Salvioli.

\section{2- 0 símbolo como unidade da obra Ricoeuriana}

A tese de Marco Salvioli (2009) se distancia um pouco da tese de Jervolino. Salvioli compreende que a tese de Jervolino acaba por colocar o símbolo apenas na primeira fase da obra de Paul Ricoeur. No artigo publicado na Revista Divus Thomas (n.112) no ano de 2009, ano do cinquentenário de publicação de Le symbole donne à penser (1959), Marco Salvioli apresenta a sua hipótese acerca da unidade da obra do filósofo francês morto em 2005.

Para Salvioli, ao mesmo tempo em que não se pode evitar a fascinação em pensar uma hipótese interpretativa acerca desta unidade, também, não se pode ser persuadido pelo fato de que a fenomenologia hermenêutica do símbolo constitui simplesmente e exclusivamente a primeira das três fases que, por exemplo, na síntese de Domenico Jervolino, é pontuada como o vetor do desenvolvimento da vasta obra Ricoeuriana. 
De acordo com Salvioli, "O símbolo representa mais o fundo permanente, embora não determinante nem último, do desenvolvimento de qualquer outro momento da filosofia da interpretação proposta por Ricoeur [... ${ }^{\prime 94}$.

0 texto de Salvioli traz-nos uma passagem retirada de Introduzione a Ricoeur (2003) em que Jervolino apresenta sua hipótese interpretativa acerca da unidade da obra Ricoeuriana:

Em primeiro lugar direi que como o paradigma do texto não elimina, mas complementa aquele do símbolo, para a introdução de um terceiro paradigma, que não contradiz os anteriores, mas completa-os. Acrescento que a progressão dos três paradigmas - símbolo, texto e tradução - pareceme obedecer à lógica do confronto com aspectos da linguagem, pressuposto anterior a toda hermenêutica, que são, por assim dizer, de grandeza crescente ${ }^{95}$.

E a este respeito, Salvioli acrescenta: "do nosso ponto de vista, o valor permanente do símbolo emerge como o fundo de entrelaçamento desses três paradigmas no curso da obra Ricoeuriana" ${ }^{96}$.

Ainda a fim de demonstrar uma possível objeção à sua hipótese, Salvioli cita uma passagem do próprio Ricoeur, na qual o filósofo reconsiderando o desenvolvimento de sua própria proposta teórica no ensaio cujo título em italiano é Dellinterpretazione (1983), reserva à função de simples etapa ao momento simbólico:

94 Cfr. 2009, p.14, tradução nossa: "Il simbolo rappresenterebbe piuttosto lo sfondo permanente, benché non determinante né ultimativo, dello sviluppodiognialtro momento della filosofia dell'interpretazione proposta da Ricoeur [...].

${ }^{95}$ Cfr. JERVOLINO apud SALVIOLI, 2009, p.14, tradução nossa: "In primo luogo dirò che come il paradigma del testo non elimina ma integra quello del simbolo, così l'introduzione di un terzo paradigma non contrad dice i precedenti ma li completa. Aggiungerò che la progressione dei tre paradigmi - simbolo, testo, traduzione - mi sembra obbedire alla logica di un confronto con aspetti del linguaggio, presupposto prima di ogni ermeneutica, che sono per così dire digrandezza crescente". ${ }_{96}$ "Dal nostro punto di vista, il valore permanente del simbolo emergerebbe come lo sfondo dell'intreccio di questi tre paradigmi nel corso dell'opera ricoeuriana". 
A hermenêutica não pode mais ser definida simplesmente mediante a interpretação do símbolo. No entanto, tal definição não deve ser conservada como uma espécie de etapa entre o próprio reconhecimento geral da experiência linguística e a definição mais técnica da hermenêutica em termos da interpretação textual. Também, essa contribuiu para dissipar a ilusão de um conhecimento intuitivo de si mesmo, impondo-se a compreensão do grande desvio através do tesouro dos símbolos transmitidos através das culturas em que veio à existência juntamente com a palavra ${ }^{97}$.

Para Salvioli, na passagem citada acima, Ricoeur estaria falando sobre o desvio através das mediações que conduzem à mediação do si; e neste sentido, 0 autor deslocaria o símbolo colocando-o após o signo e, desta forma, favorecendo o momento estrutural a respeito de uma apresentação hereditária da própria hermenêutica, e acaba por reduzir o seu papel em função do paradigma do texto. Assim, a partir deste testemunho irrefutável o leitor poderia sentir-se autorizado a marginalizar o símbolo, no quadro de pensamento de Ricoeur, isto é, reduzi-lo à fase de Finitude et culpabilité (1960) (SALVIOLI, 2009, p.14). E, Salvioli acrescenta que:

Esta consideração requer entender o que Ricoeur disse, em sentido mais preciso, em nossa opinião. 0 que é para ser considerado como uma fase ultrapassada pelo paradigma do texto, para a compreensão da teoria da hermenêutica, é a produção específica sobre a linguagem da culpa, isto é, a análise hermenêutica dos símbolos, relacionada com o projeto de uma filosofia da vontade, e não o simbólico tout court. O valor permanente do símbolo não pode ser, de fato, posto de lado como evidência da opacidade do si, que exige o desvio pelas próprias mediações culturais e 0

${ }^{97}$ Cfr. RICOEUR apud SALVIOLI, 2009, p.29, grifo nosso: "L'ermeneutica non può più essere definita semplicemente mediante l'interpretazione dei simboli. Pure, tale definizione deve essere conservata come una sorta di tappa tra il riconoscimento molto generale del carattere linguistico dell'esperienza e la definizione più tecnica dell'ermeneutica in termini d'interpretazione testuale. Inoltre, essa contribuisce a dissipare l'illusione di una conoscenza intuitiva di sé, imponendo alla comprensione di sé la grande deviazione attraverso il tesoro dei simboli trasmessi attraverso le culture entro le quali siamo venuti all'esistenza e insieme alla parola" (grifo nosso). 
enraizamento das culturas no mundo-da-vida, que demonstra o resultado da linguagem do mundo, e a transmissão desse enraizamento com a transmissão mesma da linguagem. Em outras palavras, é a natureza simbólica da linguagem que protege a profundidade ontológica. Atestando 0 fato de que a linguagem pode voltar para o mundo, porque vem do mundo, objetivando-se então como signo e como texto, tornando-se possível, basicamente, algo como a referência do mundo e do signo e do texto. Em outras palavras, talvez seja o símbolo para e na consciência a legitimar toda a filosofia Ricoeuriana exigindo a superação da atitude filosófica moderna que se baseia, de Descartes a Husserl, na transparência do Cogito98.

Segundo Salvioli, se a tese de Jervolino está correta, apesar das críticas levantadas contra a imaturidade do paradigma da tradução, o surgimento deste paradigma relativizaria mais a centralidade do texto em favor de uma compreensão maior da hermenêutica, que em sua opinião, é um elemento indispensável e não só uma etapa, embora valiosa, pelas razões acima mencionadas. Para ele, esta consideração depende, de fato, não apenas da fecunda correlação entre a interpretação e o símbolo, mas a partir da constatação de uma tensão no que diz respeito ao significado do momento simbólico da hermenêutica, estendido entre a sua manutenção e sua relativização (SALVIOLI, 2009, p.15).

98 Cfr. SALVIOLI, 2009, p.14-15, tradução nossa: "Proprio questa considerazione impone di comprendere quanto Ricoeur ha affermato in un senso, a nostro avviso, più preciso. Ciò che è da considerarsi come una tappa superata dal paradigma del testo, per la comprensione della teoria ermeneutica, è la specifica produzione sul linguaggio della colpa, ossia l'analisi ermeneutica dei simboli relativi al progetto di una filosofia della volontà e non il simbolico tout court. II valore permanente del simbolo non si può, infatti, mettere da parte in quanto testimonia dell'opacità del sé, che richiede la deviazione attraverso le mediazioni culturali stesse, e il radicamento delle culture nel mondo-della-vita che testimonia dello scaturire del linguaggio dal mondo e della trasmissione di questo radicamento con la trasmissione stessa del linguaggio. In altre parole, è il carattere simbolico del linguaggio che ne salvaguarda lo spessore ontologico. Testimoniando del fatto che il linguaggio può rinviare al mondo perché viene dal mondo, oggettivandosi poi come segno e come testo, rende in fondo possibile qualcosa come il riferimento al mondo e del segno e del testo. In altre parole, è il darsi del simbolo alla e nella coscienza a legittimare l'intera filosofia ricoeuriana richiedendo il superamento dell'atteggiamento filosofico tipicamente moderno che si fonda, da Descartes a Husserl, sulla trasparenza del Cogito". 
De acordo com Salvioli, Ricoeur continua com o tema do símbolo e mais, justifica a sua conservação quanto à manutenção do valor filosófico da plenitude de significado e da relação com o ser e, de certa forma, tende a limitá-lo em sua elaboração hermenêutica que, provavelmente depois de sua relação cada vez mais próxima com Gadamer, concentra-se fortemente no texto. Mas o símbolo continua a aparecer constantemente em sua obra, pelo menos até a publicação de Temps et récit (1983-1985), onde a proposta Ricoeuriana em torno do chamado paradigma do texto é mais original (SALVIOLI, 2009, p.15).

A este respeito, Salvioli acrescenta:

Se a presença discreta do símbolo pode ser vista a serviço do enraizamento da metáfora e da poética na Lebenswelt - mantendo a referência ao que transcende a própria linguagem e precede a própria reconfiguração criativa que atrai a atenção de Ricoeur naqueles anos, alcançando a semântica da ação -, o ressurgimento do tema da história e da memória e o aparecimento, mesmo tímido, do incipiente paradigma da tradução torna possível considerar a recuperação atualizadora do símbolo com e sobre o percurso testemunhado pela produção de Ricoeur ${ }^{99}$.

$\mathrm{Na}$ análise de Salvioli, o paradigma do texto faz sua primeira aparição em Le conflit des interprétations (1969), sobretudo no artigo Le problème Du Double sens comme problème herméneutique et comme problème sémantique. E ele acrescenta que, de acordo com a divisão sugerida por Jervolino, entre os paradigmas da hermenêutica, pode-se assumir este ensaio como o ponto de virada do paradigma do símbolo ao paradigma do texto.

Neste ensaio o simbolismo é essencialmente multiplicidade semântica; e é retomado em vários níveis com a interpretação da semântica lexical e da

\footnotetext{
99 Cfr. SALVIOLI, 2009, p.15, tradução nossa: "Se la discreta presenza del simbolo è strategicamente da vedersi al servizio del radicamento della metafora e ella poetica nella Lebenswelt - conservando quel rimando a ciò che trascende il linguaggio stesso e precede la stessa operazione di rifigurazione creativa che catalizza l'attenzione del Ricoeur di quegli anni proteso alla semantica dell'azione -, il riemergere del tema della storia e della memoria e l'affacciarsi, pur timido, ell'incipiente paradigma della traduzione, rende forse possibile considerare la ripresa attualizzante del simbolo con e oltre il percorso testimoniato dalla produzione di Ricoeur".
} 
semântica estrutural. Salvioli afirma que "podemos dizer que a hermenêutica caracterizada pelo paradigma do texto, confirma o perfil simbólico da reflexão Ricoeuriana que vem a pensar o texto não como superação, mas como outra dimensão do problema dos múltiplos sentidos que é próprio do simbólico" ${ }^{100}$. Ainda acerca do paradigma do texto, Salvioli (2009, p.29, tradução nossa) diz:

A hermenêutica do texto é a hermenêutica do símbolo colocada em outro nível, em conexão com outra história e convidada a explorar outras dimensões da linguagem, não menos importantes que a diferença entre oralidade e escrita, mas o núcleo Ricoeuriano é o mesmo e está relacionado com o simbólico: abertura do universo dos signos e tomada da linguagem do ser, atenção à transição entre o não-linguístico (realidade, experiência, existência) e a linguagem, poder revelador da linguagem que diz e, mais precisamente a multiplicidade semântica ${ }^{101}$.

Com a intenção de embasar sua hipótese, Salvioli cita as seguintes passagens de Le conflit des interprétations: "para o hermeneuta é o texto que tem um sentido múltiplo" e acrescenta: "o único interesse filosófico do simbolismo é que ele revela, por meio da sua estrutura de duplo-sentido, a equivocidade do ser: '0 ser se diz de múltiplos modos'" (RICOEUR apud SALVIOLI, 2009, p.29).

Dito isso, Salvioli complementa:

A passagem entre os dois paradigmas é conduzida pela fidelidade à intuição inicial: é o simbolismo que informa a multiplicidade semântica e o texto é pensado a partir do símbolo, embora diga mais pelo símbolo. Ou seja, oferecendo mais argumentos, sobre a função do signo do que ao

\footnotetext{
100 "Si può dire che l'ermeneutica caratterizzata dal paradigma del testo conferma il profilo simbolico dela riflessione ricoeuriana che viene a pensare il testo non come superamento, ma come dimensione ulteriore del problema del senso molteplice che è propria del simbolico".

101 "L'ermeneutica del testo è l'ermeneutica del símbolo collocata su di un altro piano, relativamente ad un'altra storia, e chiamata ad esplorare altre dimensioni del linguaggio, non da ultimo la differenza tra oralità e scrittura, ma il nucleo ricoeuriano è il medesimo ed è correlato al simbolico: apertura dell'universo dei segni e presa del linguaggio sull'essere, attenzione al passaggio tra il non-linguistico (realtà, esperienza, esistenza) e il linguistico, potenza rivelatrice del linguaggio che dice e, appunto, la molteplicità semantica".
} 
texto, no novo horizonte estruturalista e pós-estruturalista que lança a esfera semiológica à consciência e à história ${ }^{102}$.

Por fim, a proposta de Salvioli é a de "uma filosofia da tradução ciente da simbólica"103. Para ele, o Ricoeur da hermenêutica dos símbolos pretendia responder ao desafio lançado pela modernidade: um esvaziamento de sentido em torno das figuras tradicionais do Sagrado, um ateísmo religioso e de valores, que avança para a desertificação de sentido produzido pela crescente influência da técnica. Portanto, a tradução aparecia como o instrumento não privado da tonalidade secularmente apocalíptica, para a realização de uma escatologia horizontal e restrita, capaz de atrair em torno de si a esperança e o desejo de uma vida protegida e realizada. Neste sentido, Salvioli nos traz uma citação da obra Ricoeuriana:

\begin{abstract}
É preciso compreender para crer: com efeito, nunca o intérprete se aproximará daquilo que diz o seu texto se não vive na aura do sentido interrogado. E, contudo, é apenas ao compreender que nós podemos crer, visto que o segundo imediato que nós procuramos, a segunda ingenuidade que nós esperamos, não nos são mais acessíveis noutro sítio senão numa hermenêutica; nós apenas podemos crer ao interpretar. É a modalidade "moderna" da crença nos símbolos; expressão da aflição da modernidade e remédio para essa aflição. [...] Assim, a hermenêutica, aquisição da "modernidade" é um dos modos pelos quais essa "modernidade" se supera enquanto esquecimento do Sagrado (RICOEUR apud SALVIOLI, 2009, p.33).
\end{abstract}

102 Cfr. 2009, p.29, tradução nossa: "È il simbolismo che dice la molteplicità semantica e il testo è pensato a partire dal simbolo, benché dica altro dal simbolo. Ossia offra più argomenti, in ordine alla funzione del segno rispetto al testo, nel nuovo orizzonte strutturalistico e post-strutturalistico che lancia la sfida semiologica alla coscienza e alla storia".

${ }^{103}$ Cfr. 2009, p.33: "Una filosofia della traduzione consapevole della simbólica". 
Em vista disso, então Salvioli questiona-se: "o que é hoje a hermenêutica simbólica, num contexto religioso renovado, marcada por um retorno da religião, ou melhor, das religiões? 104".

E responde dizendo que, ao reler o Le symbole donne à penser, cinquenta anos após a sua publicação é impossível que não seja provocado uma vez que se entende 0 valor permanente do símbolo e sua inesgotável dinâmica heurística, 0 desejo de propor contra os desafios dessa humanidade plural, da Babel linguística, cultural e religiosa, uma hermenêutica que desenvolva a capacidade do símbolo de mostrar que a unidade profunda e opaca que combina o anthropos em relação a uma pluralidade indelével. Se a unidade pode ser encontrada, é o que parece indicar o simbólico, será aquela do mundo-da-vida, em que surge a linguagem - e então o mundo vem intersubjetivamente constituído - a partir da fronteira entre 0 bios e o logos, em uma palavra, no confronto daquele horizonte pré-conceitual caracterizado desde a inesgotabilidade do sentido pluralmente original.

A hipótese interpretativa de Salvioli mostra que é possível despertar o simbólico dentro do paradigma da tradução, assim como, segundo ele, Ricoeur teria feito com o paradigma do texto, cruzando metáfora, história e símbolo. A hermenêutica dos símbolos pode, no contexto do paradigma da tradução, exercer a função heurística e, ao mesmo tempo, permitir ao homem radicar-se no mundoda-vida, enquanto experimenta a tarefa que ele chama de teologia implícita no conceito. Portanto, para Salvioli, atualmente, em continuidade com o último Ricoeur, bem como desenvolveu Domenico Jervolino, é necessário deixar falar o símbolo no contexto fornecido pelo paradigma da tradução (SALVIOLI, 2009, p.34).

Parece-nos que mesmo não sendo totalmente opostas as duas teses apresentadas, elas desconsideram uma informação importante, que é o fato do próprio Ricoeur quando indagado sobre um "fio condutor" ou mesmo uma unidade à sua obra, disse que estava mais sensivel às rupturas do que à continuidade da sua obra. Somente no ano de 2000, Ricoeur permitiu enquanto leitor e revisor da

\footnotetext{
104 "Che ne è oggi dell'ermeneutica simbolica, in un rinnovato contesto religioso, segnato da um pur ambiguo ritorno della religione o meglio delle religioni?".
} 
sua própria obra indicar um "sutil mas contínuo fio". É acerca dessa releitura das obras, realizada pelo próprio Ricoeur, que nos ocuparemos na próxima seção.

\section{3- Paul Ricoeur e o homem capaz}

Paul Ricoeur manteve-se sempre muito reservado quando questionado acerca da continuidade da sua obra, ou mesmo de um "fio condutor", reconhecendo aos seus leitores o direito as suas próprias leituras e interpretações, mas reconhecendo-se mais sensível às rupturas do que a continuidade da sua obra, principalmente ao afirmar que cada um de seus livros nasceu de um tipo de resíduo deixado em aberto no precedente.

Somente no ano de 2000 Ricoeur aceitou, como leitor e revisor de sua própria obra, indicar um fio condutor, segundo ele, "um fio tênue, mas contínuo" e o viu no tema do "'homme capable". Contudo, ele próprio aponta que mesmo sua releitura não é mais que uma releitura pessoal que não pretende valer mais do que as outras.

No artigo Proménade au fil d'un chemin (2000), diz Ricoeur:

À primeira vista, minha obra é bastante dispersiva; e ela se parece assim
porque cada livro se organiza em torno de um problema bem definido: o
voluntário e o involuntário, a finitude e o mal, as implicações filosóficas da
psicanálise, a inovaçãa semântica atuante na metáfora viva, a estrutura
linguística da narrativa, a reflexividade e os seus estágios. Foi somente nos
últimos anos que pensei poder colocar a variedade de tais aproximações
sob o título de uma problemática dominante: escolhi o título do homem
agente e do homem capaz de... [...] É, pois, em primeiro lugar o poder de
recapitulaçãa inerente ao tema do homem capaz de... Que me pareceu,
contrariamente à aparência de dispersão da minha obra, como um fio
condutor equiparável àquele que tanto admirei em Merleau-Ponty durante
os meus anos de aprendizagem: o tema do 'eu posso' (RICOEUR, 2000,
p.15-16).

Para Ricoeur este tema já aparece em Le volontaire et l'involontaire como "a capacidade do projeto confrontada com suas condições de exercício, como 0 hábito e a emoção, e com os seus limites insuperáveis, o caráter, o inconsciente, a 
vida". Após meio século, esse tema irá retornar em Soi-même comme un autre, podendo ser lido a partir de quatro modalidades do "eu posso": eu posso falar, agir, narrar e imputar, as ações por mim praticadas.

Neste sentido, Ricoeur coloca:

Sob estes quatro títulos eu podia retomar sucessivamente as minhas contribuições para a filosofia da linguagem e para a sua organização na base de três unidades da palavra, frase e do texto, e também as minhas contribuições para a filosofia da ação, com as suas causas e os seus motivos e a sua inserção no mundo, e ainda a minha concepção da narrativa, com o seu poder de estruturação na vida cotidiana, na literatura, na histografia e na especulação sobre o tempo - enfim, as minhas ideias acerca da filosofia moral. Devo afirmar que é justamente no campo da filosofia moral que o poder de organização do tema do homem capaz de... me pareceu ainda que tardiamente. $O$ conceito de imputação é 0 último chegado à minha obra, no ponto de articulação entre o plano narrativo e 0 ético. [...] Por sua vez, tal tema, tal tema da imputabilidade cedeu lugar a uma nova articulação interna entre a ética fundamental que governa 0 desejo de uma vida realizada, a moral da obrigação moral e o seu horizonte de felicidade nas esferas práticas distintas, a esfera da arte médica, a da justiça institucional, a da histografia (mediante as suas fazes documentária, explicativa e narrativa), e enfim a esfera do juízo políico, confrontado com os universos contrapostos da economia e da cultura, da soberania e da globalização (Ibid., p.16).

Considerando-se esse fio que nos apresenta o próprio Ricoeur, a saber: 0 homem capaz de..., pode-se dizer que a filosofia Ricoeuriana não se fecha em si mesma, mas que se caracteriza como uma atividade para pensar e promover, nas suas múltiplas formas, a humanidade do homem (JERVOLINO, 2011, p.76).

Em Barcelona em 2001, em sua Lectio magistralis, Ricoeur declarou que os inúmeros problemas cujos quais ele intentou dar uma solução, mesmo que teórica, podiam ser agrupados em torno de um eixo central que seria o "eu posso".

Portanto, vê-se surgir, em meio a aparente heterogeneidade, um tema comum, que perpassa toda a obra Ricoeuriana. Na citação anterior percebe-se que o próprio Ricoeur deixou claro o momento do nascimento desta temática, 0 
"homem capaz de...", no entanto, há alguns intérpretes ${ }^{105}$ que defendem que 0 tema do homem capaz surge no Soi-même comme un autre até o texto Sur la traduction que reúne dois ensaios Défi et bonheur de la traduction (1997), Le paradigme de la traduction (1998), sendo este último publicado na Esprit de 1999, e que a capacidade e a filosofia da ação passam a ocupar o lugar de destaque que até então era do tema da falibilidade.

A nosso ver, o tema do homem capaz está presente desde Le volontaire et l'involontaire (1950) período em que nasce a filosofia própria de Ricoeur, e o acompanhará até a sua última obra publicada em vida, ou seja, até o Parcours de la reconnaissance (2004). Neste sentido, podemos conferir Le vocabulaire de Paul Ricoeur. "O homem capaz é aquele que não é apenas um homem, mas que é "agente", mostra em todas as suas lutas, também o "sofrimento". É um homem dividido entre sua responsabilidade e sua vulnerabilidade. Um mesmo fio liga, neste sentido, a fenomenologia da vontade, a antropologia do homem falivel e a hermenêutica do homem capaz" (ABEL, 2007, p.34).

Neste sentido, Ricoeur desenvolve uma análise sobre as capacidades atestadas e reconhecidas, mas a novidade dessa análise não se limita à amplitude e ao caráter ordenado do percurso das figuras do "eu posso", mas consiste, no caráter indireto, mediato, que parece caracterizar uma abordagem hermenêutica nas filosofias reflexivas e 0 autor reconhece sua dívida a Jean Nabert pela sua atenção dedicada ao desvio dado pelo lado "objetal" das experiências consideradas do ponto de vista das capacidades colocadas em ação. Portanto, a hermenêutica do si é a consideração das capacidades que encontram expressão na forma modal do "eu posso", desvio pelo objetal para conferir valor reflexivo ao si mesmo. Logo, a afirmação do "eu posso" que qualifica como sujeito moral "o homem capaz de...", que é aquele ser que age e que sofre, o homem capaz de agir, capaz de fazer mal, capaz de sofrer... É o homem e as suas múltiplas capacidades.

\footnotetext{
105 Neste sentido, conferir: FIASSE, Gaëlle, et al. Paul Ricœur. De I'homme faillible à l'homme capable. $1^{\mathrm{a}}$ ed. Paris: Puf, 2008.
} 
Por fim, diante deste "fio tênue mas contínuo" apontado pelo próprio Ricoeur, é possível perceber que ao menos nos dois momentos que o filósofo foi impelido a escrever sobre um "fio condutor" ou algo que dessa alguma unidade à sua obra, ele nos apontou uma preocupação que tinha desde a sua juventude com relação à problemática do imediato e do mediato, o momento reflexivo da filosofia e a imediatidade da consciência.

A nosso ver, a multiplicidade das operações do sujeito e dos sinais, nos quais elas se objetivam, e com as quais 0 filósofo francês esteve desde jovem preocupado e 0 que marca 0 seu interesse pela fenomenologia e pela filosofia reflexiva, é o que the conduz aos problemas da sua obra, ou seja, o conduziu às capacidades do homme capable. Não é possivel pensar uma compreensão de si que não seja mediada através de sinais, símbolos e textos.

Portanto, na tentativa de separar o método reflexivo da afirmação idealista/subjetivista do primado da consciência, que ele chega a Hegel e a Fenomenologia do Espírito, mas acaba por renunciar a essa tentação, de uma mediação totalizante, que tem como télos o Espírito Absoluto. Mas essa renúncia não lhe impede de aceitar até certo ponto Hegel, ou seja, ele aceita a proposta de uma mediação, mas uma mediação aberta, imperfeita, uma dialética fragmentária... Ainda que com caráter teleológico, como a de Hegel, mas que tem como télos a alteridade, tomada em seu caráter positivo, a saber: "viver bem com e para os outros em instituições justas".

Neste sentido, compreendemos que as tentativas dos intérpretes de Ricoeur em indicar uma unidade à sua obra, acabam por cair justamente no que ele queria evitar: a totalização. Talvez por pensar numa mediação imperfeita, aberta, fragmentária, que ele tenha se preocupado com os vários problemas com que se preocupou durante o seu percurso filosófico, sempre aplicando o seu marco teórico, a mediação, a dialética, uma vez que essa mediação tem seu lugar na realidade humana, na praxis, como foi possível evidenciar no terceiro capítulo desse estudo.

Portanto, não é nossa pretensão colocar a mediação imperfeita como unidade da obra de Paul Ricoeur, uma vez que não pretendemos totalizar a obra do filósofo, apenas acreditamos ter demonstrado o que the conduziu aos mais 
variados temas e problemas durante o seu percurso filosófico, qual o seu marco teórico, algo singular, que ele utilizou para desenvolver as suas e refutar alguns adversários, mas não qualquer adversário, como ele mesmo declarou numa entrevista, ele escolheu os melhores adversários. Logo, isso explica as discussões travadas com Kant, Hegel, Husserl e tantos outros. 


\section{CONCLUSÃO}

Neste estudo investigamos o problema da mediação imperfeita em Paul Ricoeur. A relevância do estudo se dá justamente pela abordagem realizada, uma vez que não buscamos compreender a mediação imperfeita como um problema e/ou conceito na obra do autor, mas buscamos demonstrar que ela perpassa toda sua obra desde Le volontaire et l'involontaire (1950) até o final de seu percurso filosófico, como um marco teórico que ele aplica diante dos conflitos que encontra.

O primeiro capítulo marca a inquietação de Ricoeur com a imediatidade da consciência, a sua não aceitação do caráter imediato Cogito cartesiano e da apoditicidade do "eu penso" kantiano. No qual destacamos os aspectos que estão intimamente ligados ao objeto deste estudo, a saber: a mediação imperfeita. Embora a abordagem tenha sido bastante sintética diante da vasta obra do autor, nossa intenção foi demonstrar que a cada novo livro o filósofo se preocupara com um problema diferente, o que caracteriza, grosso modo, o caráter fragmentário da sua obra. Demonstramos ainda que em várias das suas obras retorna o tema da imediatidade e apodicticidade da consciência e a dificuldade em aceitar Hegel e a sua pretensão de uma mediação total. Ricoeur reconhece que essa saída hegeliana pela via da mediação totalizante não pode ser considerada como alternativa ao problema.

Portanto, no segundo capítulo, nos ocupamos em demonstrar quais os motivos de Ricoeur para anunciar uma renúncia a Hegel e o fizemos em três momentos. Demonstrando as três tentações hegelianas apontadas por Ricoeur: a primeira tentação que diz respeito ao conflito entre ontologia e antropologia, cuja alternativa apresentada por Hegel é rejeitada por Ricoeur, por se tratar de um Espírito absoluto, assim como as alternativas apontadas pelos hegelianos, como Hyppolite, que segundo o próprio Ricoeur conseguiu ser mais hegeliano do que 0 próprio Hegel pretendeu. Ricoeur teme o perigo trazido por uma dedicação exagerada à ontologia (ao ser) que acaba se esquecendo do homem e de sua subjetividade (sua história objetiva). A partir do que propõe hegelianismo, a exemplo de Hyppolite, para Ricoeur foi possível concluir: o ser é o seu próprio Logos; esse Logos é a própria reflexão e a reflexão é a sua própria alienação. 0 
filósofo francês não aceita essa cisão entre o si e o homem proposta por Hegel, ao mesmo tempo em que não é possível aceitar a saída dada por Hyppolite, de uma ontologia partida. Logo, evidenciamos que diante do conflito entre ontologia e antropologia, é necessário que se evite cair na tentação hegeliana.

A segunda tentação a ser evitada é que, uma vez reconhecida a potência do pensamento de Hegel, não se caia na mediação absoluta, na totalização. É preciso que se evite, no que tange à razão prática, que, como ficou demonstrado, ao tentar sair de Kant se caia em Hegel. Para Ricoeur, quando Kant eleva à categoria de princípio supremo a regra de universalização, ele acaba por seguir 0 mesmo caminho que seguiram os demais filósofos desde Fichte até Marx, estabelecendo a ordem prática como passível de justificação de um saber e de uma cientificidade que podem ser comparados a um saber e uma cientificidade que são requeridos na ordem teórica. Sendo assim, a tentação hegeliana consistia em se deixar seduzir pela ideia de que é necessário procurar na Sittlichkeit - vida concreta - as origens e os recursos da ação sensata. Diante da ideia esvaziada da lei, Ricoeur assume Hegel, ao menos com relação à ética concreta, e também Aristóteles, com relação ao "bem do homem" e a sua "tarefa". Para Ricoeur, se em Kant tínhamos a dicotomia entre a intenção e o fazer, em Hegel, com a pretensão do saber, teremos uma dicotomia entre o Estado de intenção e o Estado real. A saída proposta por Ricoeur é através da tensão entre ideologia e da utopia. Como demonstramos, ele acredita que a utopia tem como papel principal lembrar que a razão prática não existe sem a sabedoria prática.

A terceira tentação hegeliana consistiu na proposta de totalização da história. Para Ricoeur, a proposta de Hegel pode ser resumida na seguinte premissa: a filosofia traz a simples ideia de Razão e a Razão governa o mundo; logo a história universal também se dá racionalmente. $O$ motivo de sua incredulidade é justamente pelo fato de que ela, a história, se fundamenta na própria razão.

No terceiro capítulo deste estudo, demonstramos até que ponto 0 pensamento de Ricoeur se aproxima e se distancia do pensamento de Hegel. Ricoeur recusa a mediação total proposta pelo autor da Fenomenologia do Espírito, mas não recusa a noção de mediação. Pudemos demonstrar os quatro pontos apontados por Ricoeur que caracterizam o "lugar" da sua mediação, onde ficou posto que, para o filósofo, o "lugar" da mediação é a realidade humana, é a práxis humana. Além disso, ficou posto que Ricoeur manteve a ideia de uma 
mediação não totalizante, aberta, uma mediação que visa um télos que não é 0 Saber Absoluto, como em Hegel, mas, sim, a alteridade.

No quarto capítulo abordamos os três momentos da mediação, de acordo com Ricoeur, a saber: como primeiro momento o desejo racional e a vontade; como segundo momento o espírito subjetivo; e o terceiro momento aquele da passagem da vontade objetiva à vontade subjetiva. A partir desses momentos, foi possível demonstrar que a dialética recusada por Ricoeur é aquela cuja pretensão é um Saber Absoluto, totalizante. Em troca, ele propõe uma mediação imperfeita, aberta, fragmentária.

Por fim, no último capítulo, abordamos as teses de Domênico Jervolino e Marco Salvioli. A primeira está alicerçada na ideia de que a unidade da obra de Ricoeur se manteria na sucessiva alternância de três paradigmas: o do símbolo, 0 do texto e da tradução. E a tese de Salvioli que coloca o símbolo como o "fio condutor" que amarra de início ao fim a obra Ricoeuriana. Ponderamos também que, ao lado disso, o próprio filósofo francês estava mais propenso a pensar na hipótese da fragmentação da sua obra do que em uma possível unidade abarcante. Se há um "fio condutor" ele foi elegido apenas no ano 2000, centrandose na ideia de sujeito e das suas modalidades implicadas na noção de "o homem capaz de...".

De nossa parte, procuramos demonstrar a tese de que é a busca de uma mediação imperfeita que perpassa toda a obra de Ricoeur, desde Le volontaire et l'involontaire (1950) até Parcours de la reconnaissance (2004). A mediação imperfeita é o seu marco teórico, o seu método que conduziu todas as suas discussões e diálogos durante todo o seu percurso filosófico, mas não como unidade, mas como um "fio" que direciona todas as suas discussões e suscita os mais variados temas e problemas. 


\section{REFERÊNCIAS}

\section{Obras de Paul Ricoeur}

RICOEUR, Paul. Le volontaire et l'involontaire. Paris-França: AUBIER, Éditions Montaigne, 1950.

. De l'interpretation: essai sur le Freud. Paris-França: Seul, 1965.

. Philosophie de la volonté I. Le volontaire et l'involontaire. Paris: Aubier Montaigne, 1967.

. Le conflit des interprétations. Essais d"herméneutique. Paris: Seuil, 1969.

. Da interpretação: ensaio sobre Freud. Trad. Hilton Japiassu. Brasil - Rio de Janeiro: Editora Imago, 1977.

. Finitud y culpabilidad: el hombre labil y la simbolica del mal. Itália-Madrid: Taurus Ediciones, 1982. 1983.

Temps et récit. Tome I: L"intrigue et le récit historique. França-Paris: Seuil,

Temps et récit. Tome II: La configuration du temps dans le récit de fiction. França- Paris: Seuil, 1984.

. Temps et récit. Tome III: Le temps raconté. França-Paris: Seuil, 1985.

. Du texte à l'action. Essais d"herméneutique II. França-Paris: Seuil, 1986.

. Do texto à ação. Trad.: Alcino Cartaxo e Maria José Sarabando. PortugalPorto: Rés - Editora, 1989. 
. O mal. Um desafio à filosofia e à teologia. Trad. Maria da Piedade Eça de Almeida. Brasil-São Paulo: Papirus, 1988.

. Soi-même comme un autre. Paris: Seuil, 1990.

. O conflito das interpretações: ensaios de hermenêutica. Trad.: M. F. Sá

Correia. Portugal-Porto: Editora Rés,1990.

Papirus, 1991.

. O si-mesmo como um outro. Trad.: Lucy Moreira César. Brasil-São Paulo:

. Da metafísica à moral. Trad.: Silvia Menezes. Portugal-Lisboa: Instituto Piaget, $1995 \mathrm{~b}$.

Réflexion faite. Paris: Éditions Esprit, 1995c.

. La critique et la conviction. Entretien avec François Azouvi et Marc de

Launay. Paris: Calmann-Lévy, 1995d.

- Leituras 1 - Em torno ao político. Trad. Marcelo Perine. Brasil-São Paulo:

Edições Loyola, 1995.

. Leituras 2 - A região dos filósofos. Trad. Marcelo Perine e Nicólas Nyimi Campanário. Brasil-São Paulo: Edições Loyola, 1996.

. Leituras 3 - Nas fronteiras da filosofia. Trad. Nicólas Nyimi Campanário.

Brasil-São Paulo: Edições Loyola, 1996.

. L'idéologie et utopie. Trad.: Myriam R. D'allonnes e Joël Roman. França-

Paris : Seuil, 1997.

2001.

Pensando biblicamente. Trad.: Raul Fiker. Brasil-São Paulo: EDUSC,

. Sur la traduction. França-Paris: Bayard, 2004.

. Percurso do reconhecimento. Trad.: Nicolas Nyimi Campanário. Brasil-São

Paulo: Edições Loyola, 2006. 
. A memória, a história, o esquecimento. Trad.: Alain François. Brasil-São Paulo: Editora da Unicamp, 2007.

. Ideología y utopia. Trad.: Alcira Bixio. Espanha-Barcelona: Gedisa editorial, 2008.

. O justo 1- A justiça como regra moral e como instituição. Trad.: Ivone C.

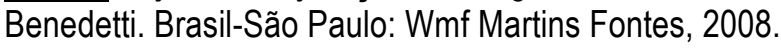

. O justo 2- Justiça e verdade e outros estudos. Trad.: Ivone C. Benedetti. Brasil-São Paulo: Wmf Martins Fontes, 2008b.

. Na escola da fenomenologia. Trad. Ephraim Ferreira Alves. Brasil-Rio de Janeiro: Editora Vozes, 2009.

. Escritos e conferências 1 - Em torno da psicanálise. Trad.: Edson Bini. Brasil-São Paulo: Edições Loyola, 2010.

. Escritos e conferências 2 - Hermenêutica. Trad.: Lúcia Pereira de Souza. Brasil-São Paulo: Edições Loyola, 2011.

. Tempo e narrativa 1 - A intriga e a narrativa histórica. Trad.: Claudia Berliner. Brasil-São Paulo: Wmf Martins Fontes, 2012.

Tempo e narrativa 2 - A configuração do tempo na narrativa da ficção. Trad.: Márcia Valéria M. de Aguiar. Brasil-São Paulo: Wmf Martins Fontes, 2012.

. Tempo e narrativa 3 - 0 tempo narrado. Trad.: Claudia Berliner. Brasil-São Paulo: Wmf Martins Fontes, 2012.

. O si-mesmo como outra. Trad.: Ivone C. Benetti. Brasil-São Paulo: Wmf Martins Fontes, 2014.

. A metáfora viva. Trad.: Dion Davi Macedo. Brasil-São Paulo: Edições Loyola, 2015.

. "Autobiografia intelectual". In: Da metafísica à moral. Trad.: Sílvia Menezes. Portugal-Liboa: Instituto Piaget, 1995a. 
"Ontologie". In: Encyclopaedia Universalis. XII. Paris: Encyclopaedia Universalis France, 1972, p. 94-102.

. "Le 'lieu' de la dialectique", In: Dialectiques, entretiens de Varna 15-22 septembre 1973, à l'occasion d'un colloque organisé par I'Institut International de Philosophie, publié par les soins de CH. Perelman, édition Martinus Nijhoff - The Hague/ La Haye.

"Parole et symbole". In: Revue des Sciences Religieuses, 49e Année, n. 12, janvier-avril, 1975a, p.142-161.

"La structure symbolique de l"action". In: Symbolisme. Conférence internationale de sociologie religieuse. Strasbourg: CISR, 1977, p.31-50.

"L"histoire comme récit et comme pratique. Entretien avec P. Ricoeur (Propos recueillis par Peter Kemp)". In: Esprit, n.54, juin, 1981, p.155-165.

. "Entre temps et récit: concorde/discorde". In: Recherches sur la philosophie et le langage "Cahier du groupe de recherches sur la philosophie et le langage del' Université de Grenoble 2». Paris: Vrin, 1982, p.3-14.

"L" identité narrative". In: Esprit, n.7-8, 1988a, p.295-304.

"Indivíduo e identidade pessoal". In: VEYNE, Paul et al. Indivíduo e poder. Lisboa: Edições 70, 1988b.

. "De la volonté à l"acte. Entretien avec Paul Ricoeur. (Propos recueillis par Carlos Oliveira)". In: BOUCHINDHOMME, Christian \& ROCHLITZ, Rainer (Éds). Temps et récit de Paul Ricoeur en débat. Paris: Cerf, 1990b, p.17-36.

. "L"homme comme sujet de la philosophie". In: Der Österreichischen Akademie Der Wissenschaften, 1990c, p.73-86.

"L" identité narrative". In: Revue des sciences humaines, v.95, n.221, 1991a, p.35-47. 
. "L"attestation: entre phenomenologie et ontologie". In: Paul Ricoeur - Les metamorphoses de la raison herméneutique. Actes du Colloque de Cerisy-La-Salle. 1er - 11 août 1988. Paris: Cerf, 1991b, p.381-403.

. "Événements et sens". In: Raisons Pratiques (Dossier L"événement en perspective), n.2, Paris: EHESS, 1991c, p.41-56.

"Autocomprehensión e historia". In: MARTINES, Tomás Calvo; CRESPO, Remedios Avila (Eds.). Paul Ricoeur. Los caminos de la interpretación. Barcelona: Anthropos, 1991d.

. "Promenade au fil d"un chemin". In: TUROLDO, Fabrizio. Indagini su Paul Ricoeur. Padova: II Poligrafo, 2000b, p. 15-20.

. "Hegel aujourd'hui [conférence donnée à la Maison de la Culture de Grenoble suivie d'une brève discussion]" In: Etudes théologique et philosophique 49, n.3, 1974, p.335- 354 [Ce texte est repris dans la revue Esprit, mars-avril 2006, La pensée Ricoeur, p.174 -194].

. "Meu caminho filosófico". In: JERVOLINO, Domênico. Introdução a Ricoeur. Trad. José Bortolini. São Paulo - Brasil: Paulus, 2011.

\section{Referências secundárias}

ABEL, Oliver. Paul Ricoeur: a promessa e a regra. Trad.: Joana Chaves. PortugalLisboa: Instituto Piaget, 1996.

ARISTÓTELES. Aristote. Arte retórica e arte poética. São Paulo: Difusão Européia do Livro, 1959.

BÉGOUT, Bruce. "L"héritier hérétique. Ricoeur et la phénoménologie". In: Esprit, v.3, mars/avril, 2006, p.195-209. 
BEGUÉ, Marie-France. Paul Ricoeur: La poética del sí-mismo. Argentina-Buenos Aires: Editorial Biblos, 2003.

BOURGEOIS, Bernard. "L'idée dialectique dans la pensée française au XXe siècle", In: Philosopher en français, sous la direction de Jean-François Mattéi, Paris, Puf/Quadrige, 2001.

BUSACCHI, Vinicio. "Posfacio - 0 desejo, a identidade e o outro". In: RICOEUR, Paul. Escritos e conferências 1 - Em torno da psicanálise. Trad.: Edson Bini. BrasilSão Paulo: Edições Loyola, 2010.

BUZZONI, Marco. Paul Ricoeur: Persona e Ontologia. Itália-Roma: Edizioni Studium, 1988.

CADORIN, Severino. O mal, interpretação de Paul Ricoeur. Brasil -Rio de Janeiro: Sotese, 2001.

CASAROTTI, Eduardo. Paul Ricoeur, una antropología del hombre capaz. $1^{\mathrm{a}} \mathrm{ed}$. Argentina-Córdoba: EDUCC, 2008.

CEZAR, Constança M. A ontologia hermenêutica de Paul Ricoeur. Reflexão, BrasilCampinas: Instituto de Filosofia, v.25, n.76, jan-abr/ 2000, p.11-17.

. "O problema do tempo em Paul Ricoeur". In: Reflexão, Brasil-Campinas: Instituto de Filosofia - PUC, v.10, n.32, mai-ago/1985, p.5-11.

CHANGEUX, Jean-Pierre; RICOEUR, Paul. O que nos faz pensar?. Trad.: Isabel Sait-Aubyn. Portugal-Lisboa: Edições 70, 1998.

CORÁ, Elsio José. "Hermenêutica e teoria da ação em "o si-mesmo como um outro" de Paul Ricoeur". Dissertação apresentada no Curso de Pós-graduação em Filosofia da UFSM. Santa Maria-Brasil: UFSM, 2004.

CORREIA , C. J. Ricoeur e a expressão simbólica do sentido. Portugal-Lisboa: Fundação Calouste Gulbenkian, 1999.

CORREIA, Adriano. "O conceito de mal radical". In: Trans/Form/Ação, 28(2), BrasilSão Paulo: UNESP, 2005, p.83-94. 
COSTA, Celso P. "O conceito de mal em Paul Ricoeur". Dissertação apresentada no Curso de Pós-graduação em Filosofia da UFSM, Brasil-Santa Maria: UFSM, 2008.

FAFIÁN, Manuel Maceiras. "Paul Ricoeur: una lectura de la condición del hombre contemporáneo". In: Koinonía - Anuario del Instituto de Doctrina Social de la Iglesia de la Pontificia Universidad Católica de Puerto Rico, ano 2005-2006. Porto RicoPonce: PUC Porto Rico, 2006, p.93-107.

FOESSEL Michaël, MONGIN Olivier. Paul Ricoeur. França- Paris: ADPF, 2005.

FRANCO, Sérgio de G. Hermenêutica e Psicanálise na obra de Paul Ricoeur. São Paulo: Loyola, 1995.

FREY, Daniel. L'interprétation et la lecture chez Ricoeur et Gadamer. Paris: PUF, 2008.

GADAMER, Hans-Georg. Verdade e Método. Vol. I, Petrópolis - Brasil: Editora Vozes, 1999.

GREISCH, Jean. "Témoignage et attestation". In: Philosophie. Paul Ricoeur L'herméneutique à l'école de la phénoménologie. França-Paris: Beauchesne Éditeur, n.16, 1995, p.305-326.

GRONDIN, Jean. "De Gadamer à Ricoeur. Peut-on parler d"une conception commune de I"herméneutique?" In: FIASSE, Gaëlle (dir.). Paul Ricoeur. De l'homme faillible à l'homme capable. França-Paris, PUF, 2008, p.37-62.

. L'herméneutique. Paris: PUF, 2006.

2003. . Le tournant herméneutique de la phénoménologie. Frabça-Paris: PUF, . Introdução à hermenêutica filosófica. Brasil-São Leopoldo: Editora Unisinos, 1999.

HARTMAN, ROBERT S. "A Razão na História - Uma Introdução Geral à Filosofia da História". In: HEGEL, Georg Wilhelm Friedrich. A Razão na história: uma 
introdução geral à filosofia da história. Trad. Beatriz Sidou. 2. ed. São Paulo Brasil: Centauro, 2001.

HEGEL, Georg Wilhelm Friedrich. Enciclopédia das ciências filosóficas em compêndio. Vols. I e III. Trad: Paulo Meneses. São Paulo: Loyola, 1995.

. Enciclopedia de las ciências filosóficas. Madrid: Alianza Editorial, 2005.

HÖFFE. Otfried. Immanuel Kant. Trad. Christian Viktor Hamm e Valério Rohden. Brasil-São Paulo: Martins Fontes, 2005.

HYPPOLITE, Jean. Ensaios de psicanálise e filosofía. Trad. André Telles. BrasilRio de Janeiro: Taurus-Timbre, 1989.

HYPPOLITE, Jean. Introduccion a la filosofia de la historia de Hegel. ArgentinaBahía Blanca: Ediciones Calden, 1970.

. Lógica y existencia. Trad. María Cristina M. Montenegro e Jesús Rodolfo S. Iracheta. México-Puebla: Universidade Autónoma de Puebla, 1987.

HYPPOLITE, Jean. Logique et existence - Essai sur la logique de Hegel. FrançaParis: Presses Universitaires de France, 1961.

JARDIN, Maria A. Da hermenêutica à ética em Paul Ricoeur: contributos para um desenvolvimento educativo e moral da literatura. Faculdade de Psicologia e Ciências da Educação da Universidade do Porto. Portugal-Porto: Universidade Fernando Pessoa, 2002.

JERVOLINO, D. Introdução a Ricoeur. Trad. José Bortolini. Brasil-São Paulo: Paulus, 2011.

. Introduzione a Ricoeur. Brescia - Itália: Editrice Morcelliana, 2003.

. "La question de l'unité de l'oeuvre de Ricoeur à la lumière de ses derniers développements . Le paradigme de la traduction" In: Archives de Philosophie, 4, Tome 67, 2004, p.659-668. 
KANT, Immanuel. Crítica da razão pura. Trad. Manuela Pinto dos Santos e Alexandre Fradique Morujão. Portugal-Lisboa: Calouste Gulbenkian, 2010.

KANT, Immanuel. Crítica da razão pura. Trad. Valerio Rohden e Udo Baldur Moosburger. Brasil-São Paulo: Nova Cultural, 1996. (Coleção Os Pensadores).

. Crítica da faculdade do juízo. (Trad. Valerio Rohden e António Marques).

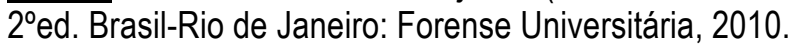

. Crítica da razão prática. Trad. Valerio Rohden. Brasil-São Paulo: Martins Fontes, 2003.

LIMA VAZ, Henrique Cláudio. A formação do pensamento de Hegel. Brasil-São Paulo: Edições Loyola, 2014.

MARCELO, Gonçalo. "Del conflito a la conciliación y vice-versa: algunas notas acerca de la dialética de Ricoeur". In: Universitas Philosophica. 31. Jul. Dez./2014, Bogotá, p.181-211.

MENESES, Paulo. Hegel e a Fenomenologia do Espirito. Brasil-Rio de Janeiro: Jorge Zahar Editor, 2003.

MÖBBS, Adriane da S. M. "O mal sofrido em Paul Ricoeur", 2009. 72 f. Dissertação de Mestrado em Filosofia - Universidade Federal de Santa Maria, Brasil- Santa Maria, 2009.

. O mal sofrido em Paul Ricoeur: um estudo acerca do sofrimento do justo.

Alemanha-Saarbrücken: NEA Novas Edições Acadêmicas, 2013.

. "Respeito e casos dificeis (hard cases) em Paul Ricoeur". In: Revista Guairacá, vol.29, n.1, 2013, p.87-107.

MONGIN, Oliver. Paul Ricoeur: as fronteiras da filosofia. Trad.: Armando Pereira da Silva. Portugal-Lisboa: Instituto Piaget, 1997.

NASCIMENTO, Cláudio Reichert do. "A questão da vida em Paul Ricoeur", SC. 2014. 236 f. Tese de Doutorado em Filosofia - Universidade Federal de Santa Catarina, Brasil- Florianópolis, 2014. 
"Identidade pessoal em Paul Ricoeur". 2009. 89 f. Dissertação de Mestrado em Filosofia - Universidade Federal de Santa Maria, Brasil-Santa Maria, 2009.

ROGER, Ir. Uma conversa com Paul Ricoeur: Libertar o fundo de bondade. Taizé, 2005. (Carta publicada após a morte de Ricoeur).

ROSSATTO, Noeli D. "Viver bem: a pequena ética de Paul Ricoeur". In: Mente, Cérebro \& Filosofia, v.11, São Paulo, 2008, p.26-33.

SALVIOLI, Marco. "II simbolo nella fenomenologia ermeneutica di Paul Ricoeur. Una proposta di ripensamento nel paradigma della traduzione". In: Divus Thomas 112, 2, 2009, p.13-64.

SCHNEM, Claudio. "A imaginação na Crítica da Razão Pura". SP. 2006. 80 f. Dissertação de Mestrado em Filosofia - Universidade de São Paulo, São Paulo, 2009.

SHEN, Ching-Kai. "L'esprit hegelien chez Paul Ricoeur - Une interpretation anthropologique de la pensee hegelienne". 2010. $352 \mathrm{f}$. Tese de Doutorado em Filosofia e Letras - Université Catholique de Louvain, Louvain, 2010.

SILVEIRA, Luciano Duarte. "Gênese e estatuto do 'factum da razão': Kant e o problema da justificação da lei moral na 'Analítica da razão prática pura'". RS. 2011. 180 f. Dissertação (Mestrado em Filosofia) - Universidade Federal de Pelotas, Pelotas, 2011.

SUMARES, Manuel. O sujeito e a cultura na filosofia de Paul Ricoeur. Lisboa Portugal: Escher, 1989.

TAYLOR, Charles. Hegel - Sistema, Método e Estrutura. Trad. Nélio Schneider. Brasil-São Paulo: É Realizações Editora, 2014.

TERROSA, Cecilia Noemí Rearte. I"maginação e síntese na Crítica da Razão Pura de Kant", RS. 2006. 108 f. Dissertação de Mestrado em Filosofia - Universidade Federal de Santa Maria, Santa Maria, 2006. 
VILLAVERDE, Marcelino A. Paul Ricoeur. A força da razão compartida. PortoPortugal: Instituto Piaget, 2003.

VILLELA-PETIT, Maria da Penha. "Perspectiva ética e busca do sentido em Paul Ricoeur". In: Síntese. Belo Horizonte, v.34 n.108, 2007. 


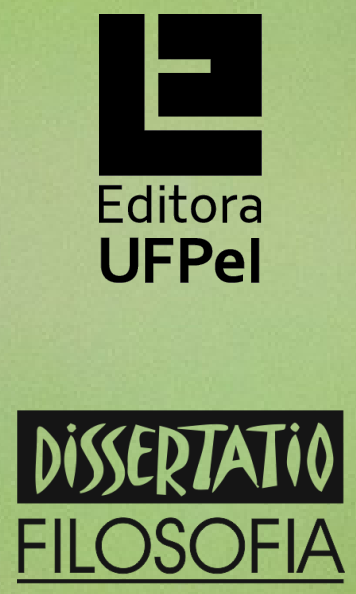